\title{
WestVirginiaUniversity
}

THE RESEARCH REPOSITORY @ WVU

Graduate Theses, Dissertations, and Problem Reports

2011

\section{Molecular Mechanisms of Chromium (VI) - Induced Toxicity and Carcinogenesis}

Djordje Medan

West Virginia University

Follow this and additional works at: https://researchrepository.wvu.edu/etd

\section{Recommended Citation}

Medan, Djordje, "Molecular Mechanisms of Chromium (VI) - Induced Toxicity and Carcinogenesis" (2011). Graduate Theses, Dissertations, and Problem Reports. 3376.

https://researchrepository.wvu.edu/etd/3376

This Dissertation is protected by copyright and/or related rights. It has been brought to you by the The Research Repository @ WVU with permission from the rights-holder(s). You are free to use this Dissertation in any way that is permitted by the copyright and related rights legislation that applies to your use. For other uses you must obtain permission from the rights-holder(s) directly, unless additional rights are indicated by a Creative Commons license in the record and/ or on the work itself. This Dissertation has been accepted for inclusion in WVU Graduate Theses, Dissertations, and Problem Reports collection by an authorized administrator of The Research Repository @ WVU.

For more information, please contact researchrepository@mail.wvu.edu. 


\title{
Molecular Mechanisms of Chromium (VI) - Induced Toxicity and Carcinogenesis
}

\author{
DJORDJE MEDAN
}

Dissertation submitted to the School of Pharmacy at West Virginia University in partial fulfillment of the requirements for the degree of

\section{Doctor of Philosophy \\ in}

\section{Pharmaceutical and Pharmacological Sciences}

\author{
Yon Rojanasakul, Ph.D., Chair \\ Vincent Castranova, Ph.D. \\ Joseph K.H. Ma, Ph.D. \\ Liying Wang, Ph.D. \\ Patrick Callery, Ph.D.
}

Department of Basic Pharmaceutical Sciences

Morgantown, West Virginia

\section{1}

Keywords: chromium (VI), cancer, lung, apoptosis, Bcl-2, malignant transformation, reactive oxygen species, interactome, Ingenuity 


\section{ABSTRACT}

\section{Molecular Mechanisms of Chromium (VI) - Induced Toxicity and Carcinogenesis}

\section{DJORDJE MEDAN}

$\mathrm{Cr}(\mathrm{VI})$ compounds are redox cycling carcinogens that induce apoptosis as a primary mode of cell death. Since defects in apoptosis regulatory mechanisms are considered to be indispensable foundation of carcinogenesis it is critical to understand the molecular effectors involved. Cellular energy powerhouses, the mitochondria, house the effectors involved in signaling cascades comprising commitment to apoptosis and are reported to be dysregulated in variety of tumors. The objective of this study was to characterize the key signaling effectors in $\mathrm{Cr}(\mathrm{VI})$-induced apoptosis and determine the relationship between those effectors and mode of cellular energy production in cancerous vs. non-cancerous cells. Our data show that $\mathrm{Cr}(\mathrm{VI})$ induced mitochondrial ROS dependent apoptosis in human lung cancer (H460) and non-cancerous (BEAS-2B) cells. The intensity of mitochondrial ROS production and consequently apoptosis was highly dependent on the energy substrate available to the cells. Forcing of oxidative phosphorylation-only energy metabolism abrogated apoptosis resistance in cancerous $\mathrm{H} 460$ cells vs. non-cancerous BEAS-2B cells. Collectively, these findings present a mechanistic advancement in the understanding of molecular effectors underlying the Warburg's "mitochondrial dysregulation" hypothesis and put mitochondrial ROS as key mediators causal agents of the commitment phase of programmed cell death in a model of $\mathrm{Cr}(\mathrm{VI})$-induced toxicity. In addition, longterm exposure to $\mathrm{Cr}(\mathrm{VI})$ leads to malignant transformation of human lung epithelial BEAS-2B cells, as indicated by their increased cell migration, invasion, proliferation, and colony formation activities. $\mathrm{Cr}(\mathrm{VI})$-transformed cells induced tumorigenesis in nude mice comparable to that of well established human lung cancer $\mathrm{H} 460$ cells, whereas passage-matched control BEAS-2B cells showed no 
tumor development. To provide a mechanistic insight to the tumorigenic process, stable knockdown mutants of $\mathrm{Cr}(\mathrm{VI})$-transformed cells and $\mathrm{H} 460$ cells exhibiting downregulated $\mathrm{Bcl}-2$ phenotype were generated and evaluated for tumor associated properties in vitro and in vivo. The Bcl-2 knockdown mutants showed a substantial decrease in the rates of colony formation, invasion, migration and proliferation, as well as tumor formation in mice, in comparison to vector controls. These results indicate a novel role of $\mathrm{Bcl}-2$, beyond apoptosis regulation, to be a key regulator of malignant transformation and tumorigenesis in vivo. The model described here may provide utility to other xeno-carcinogenesis studies, including those of heavy metals which currently lack effective in vivo tumor development experimental means. 


\title{
Dedicated to
}

\author{
Peter D. Mitchell \\ (1920-1992)
}

Whose example of ingenuity, creativity, courage and perseverance is a true testament to the Giants of science on whose shoulders we stand today. 


\section{ACKNOWLEDGEMENTS}

I want to express my sincere thanks and gratitude to my advisor, Dr. Yon Rojanasakul for his encouragement, support, patience and guidance. He is an excellent scientist and one of the best human beings I have ever known. I feel fortunate to have had the opportunity to work with him. He has taught me a lot in life and I want to thank him for making this journey a truly pleasurable one. I would also like to thank my committee members, Dr. Vincent Castranova, Dr. Patrick Callery and Dr. Joseph Ma for their insightful comments and valuable suggestions that helped me in my research. I want to express my deep appreciation and gratitude to Dr. Liying Wang for teaching me various experimental methods and advising me on my research.

I would also like to thank the faculty, staff and graduate students of the department of Basic Pharmaceutical Sciences for their help and discussion. I especially thank Yongyu Lu, an invaluable member of Rojanasakul Laboratory, for all her help and training. I am also grateful to my colleagues at NIOSH for their assistance and encouragement.

Last but not the least, I would like to share my achievement with my wife Adelheid, my son Konrad and my parents Manojlo and Milka Medan whose love and support kept me sane through my Ph.D. journey and made it worthwhile. 


\section{TABLE OF CONTENTS}

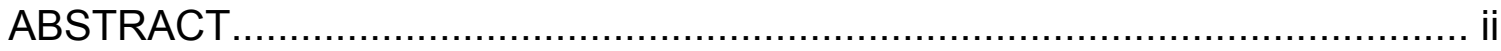

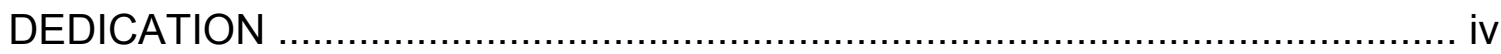

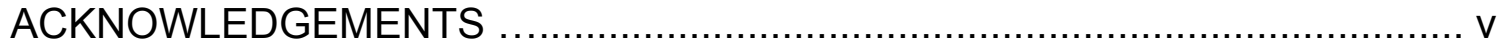

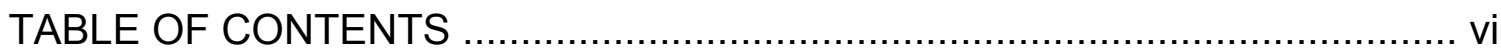

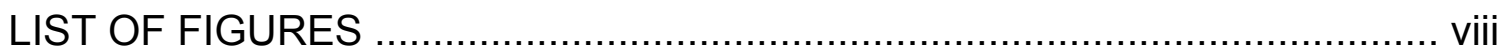

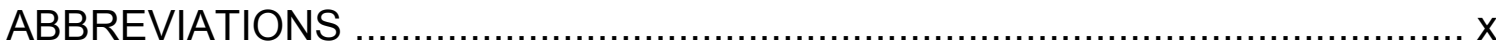

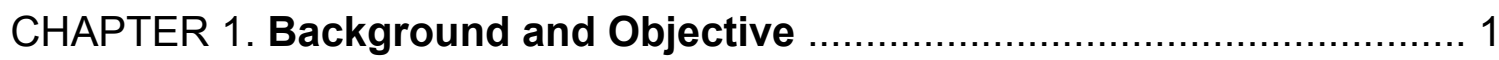

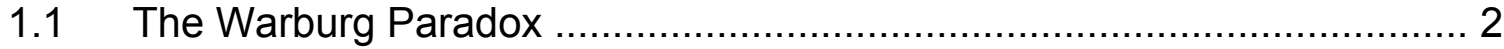

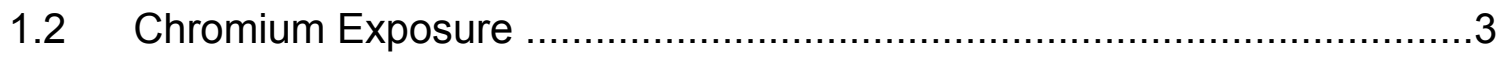

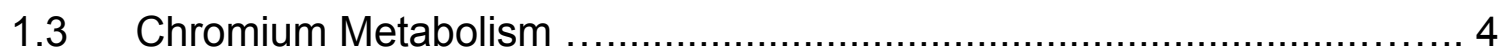

1.4 Chromium (VI)-Induced Oxidative Stress ….................................... 5

1.5 Chromium (VI)-Induced DNA Damage and Mutagenesis ...................... 7

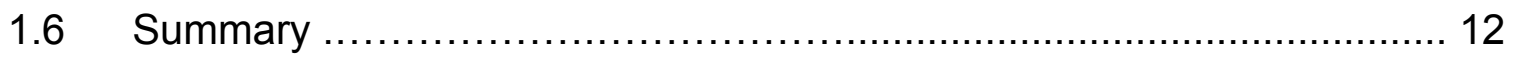

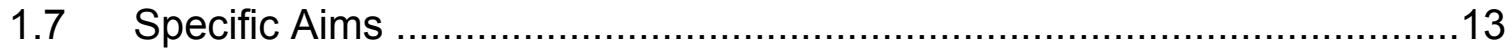

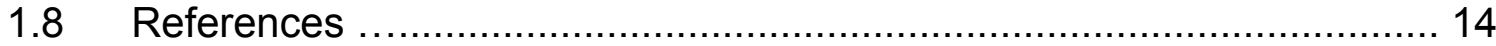

CHAPTER 2. Energy Substrate Modulates $\mathrm{Cr}(\mathrm{VI})$-Induced Apoptosis Differentially in Cancerous vs. Non-Cancerous cells via a MitochondrialReactive Oxygen Species Dependent Mechanism ................................. 20

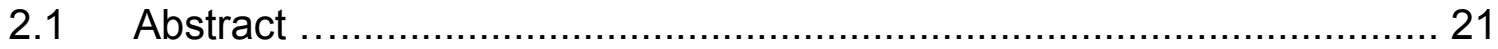

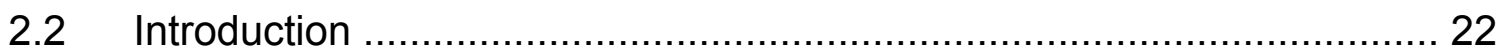

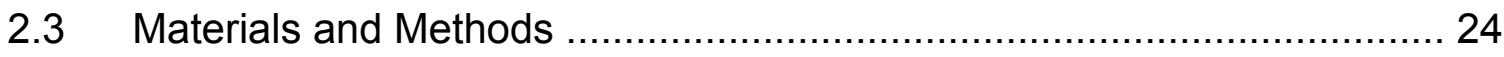

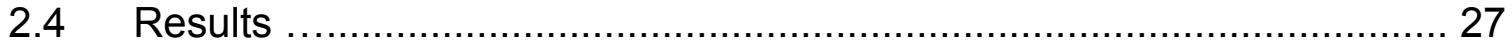

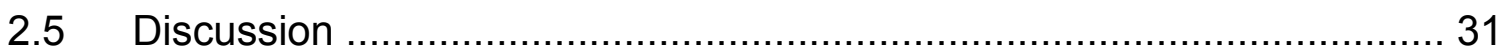

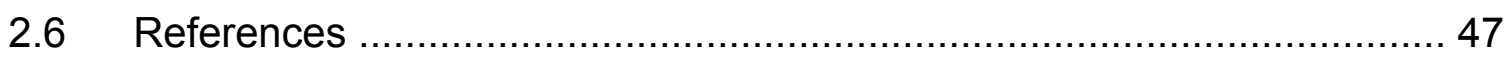


CHAPTER 3. Malignant Transformation and Tumorigenesis of Chromium (VI)-Exposed Lung Cells and their Inhibition by Bcl-2 Knockdown

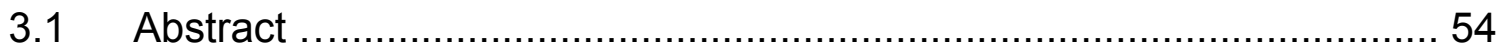

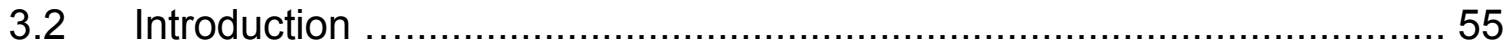

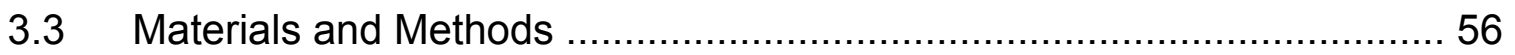

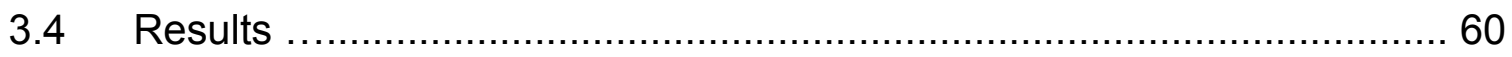

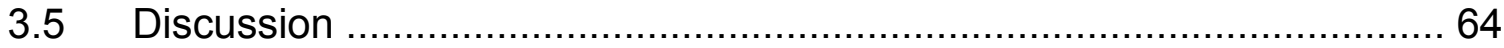

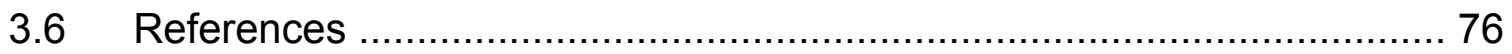

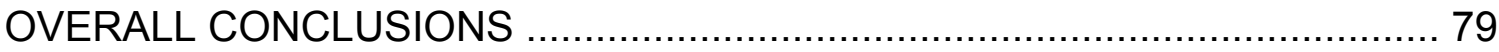

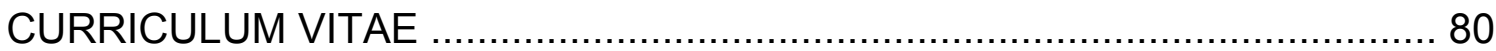




\section{LIST OF FIGURES}

\subsection{Background and Objectives}

Figure 1. Schematic Representation of Cellular Energy Metabolism 9

Figure 2. Diagrammatic Illustration of Oxidative Phosphorylation Pathway...

Figure 3. Schematic representation of known cellular reduction and cytotoxic effects of $\mathrm{Cr}(\mathrm{VI})$.

\subsection{Energy Substrate Modulates $\mathrm{Cr}(\mathrm{VI})$-Induced Apoptosis Differentially in Cancerous vs. Non-Cancerous cells via a Mitochondrial-Reactive Oxygen Species Dependant Mechanism}

Figure 1. Induction of apoptosis by $\mathrm{Cr}(\mathrm{VI})$ in human lung epithelial BEAS-2B and human lung cancer $\mathrm{H} 460$ cells

Figure 2. Effect of energy substrate on $\mathrm{Cr}(\mathrm{VI})$-induced apoptosis in human lung epithelial BEAS-2B and human lung cancer $\mathrm{H} 460$ cells

Figure 3. $\mathrm{Cr}(\mathrm{VI})$-induced ROS production and mitochondrial membrane depolarization.

Figure 4. Effect of energy substrate on ROS production and mitochondrial membrane depolarization

Figure 5. Effect of ROS modulators on $\mathrm{Cr}(\mathrm{VI})$-induced apoptosis in BEAS-2B and $\mathrm{H} 460$ cells 40

Figure 6. Localization of ROS involved in $\mathrm{Cr}(\mathrm{VI})$-Induced Apoptosis. 41

Figure 7. GPx and MnSOD overexpression increases cell death resistance to $\mathrm{Cr}(\mathrm{VI})$.

Figure 8. Bcl-2 overexpression decreases $\mathrm{Cr}(\mathrm{VI})$-induced $\mathrm{mROS}$ and apoptosis.

Figure 9. Prevailing model of carcinogenesis.

Figure 10. Mitochondrial ROS production and defense 
Figure 11. Proposed mechanism contributing to $\mathrm{Cr}(\mathrm{VI})$-induced toxicity and carcinogenesis

\subsection{Malignant Transformation and Tumorigenesis of Chromium (VI)- Exposed Lung Cells and their Inhibition by Bcl-2 Knockdown}

Figure 1. Cell growth and colony formation capacities of BEAS-2B, BEAS-Cr and $\mathrm{H} 460$ cells 68

Figure 2. In vitro relative malignant phenotype capacities of BEAS-2B, BEAS-

$\mathrm{Cr}$ and $\mathrm{H} 460$ cells

Figure 3. $\mathrm{Bcl}-2$ expression and response to $\mathrm{Cr}(\mathrm{VI})$ treatment in $\mathrm{BEAS}-2 \mathrm{~B}$, BEAS-Cr and $\mathrm{H} 460$ cells

Figure 4. Effect of Bcl-2 knockdown on tumor-associated properties in vitro

Figure 5. Effect of Bcl-2 knockdown on tumor-associated properties in vivo

Figure 6. Ingenuity Pathways Analysis software output for the Bcl-2interactome. 


\section{ABBREVIATIONS}

$\mathrm{Cr}$, chromium; $\mathrm{Cr}(\mathrm{III})$, trivalent chromium; $\mathrm{Cr}(\mathrm{VI})$, hexavalent chromium; IARC, International Agency of Research on Cancer; ATCC, American Type Culture Collection; Bcl-2, B-cell lymphoma-2; ROS, reactive oxygen species; mROS, mitochondrial ROS; $\cdot \mathrm{O}_{2}^{-}$, superoxide anion; $\mathrm{H}_{2} \mathrm{O}_{2}$, hydrogen peroxide; $\cdot \mathrm{OH}$, hydroxyl radical; NAC, $\mathrm{N}$-acetyl cysteine; DPI, diphenylene iodonium; MnSOD, manganese superoxide dismutase; GPx, glutathione peroxidase; BCA, bicinchoninic acid; BSO, buthionine sulfoximine 


\section{CHAPTER I}

\section{Background and Objectives}




\subsection{The Warburg Paradox}

Ever since Otto Warburg's 1930 observation that cancer cells prefer to derive energy from anaerobic glycolysis as opposed to, energetically speaking, much more efficient oxidative phosphorylation (Figs. 1-2), elucidation and confirmation of molecular mechanisms underlying this apparent anomaly have been underway. Although the glycolytic phenotype of many cancer cell lines and tumors has been demonstrated at biochemical and molecular levels (1-3), the 'Warburg' hypothesis of mitochondrial function impairment (4) has not been established in cancer biology. In fact, some 80 years later, we continue to seek biochemical and molecular biology evidence of mitochondria's role, and its extent, in neoplastic transformation and in maintenance and/or promotion of neoplasia. Over the past two decades, our energy reactors have taken a center stage at another process central to neoplasia - programmed cell death.

Following Andrew Wylie's 1972 observation on the significance of natural cell death in mammary gland tissue, coined apoptosis, efforts to understand its molecular effectors have taken a center stage in countless laboratories around the world. Today, we know that apoptosis is an 'active' process indispensable to support of normal physiological processes from embryonic development to maintenance of tissue homeostasis via preservation of genomic and phenotypic integrity. If the cell(s) is damaged beyond repair (i.e. xenobiotic-induced toxicity), intrinsic apoptotic pathway is activated. If the outside system (i.e. tissue, immune surveillance) deems the cell(s) undesirable, extrinsic pathway is activated. Regardless of whether intrinsic or extrinsic, the sequence of events can be summarized as: Signal Initiation, Cellular Apoptosis Commitment, and Apoptosis Execution. Finally, the cell's remnants are packaged into vesicles (apoptotic bodies) and recycled by its microenvironment. Each of the three stages is regulated by a different subset of molecular effectors with different localization. According to prevailing current evidence, mitochondrial level signaling cascades constitute the 'Commitment' stage - mitochondria decide whether the cell dies or 
not. Specifically, release of cytochrome $\mathrm{c}$ from the mitochondrial intermembrane space is generally accepted to be the molecular point of no return.

In molecular cancer research, multiple lines of evidence and reason suggest that "one renegade cell" must evade a program entrusted with maintenance of genomic and phenotypic integrity, in order to uncontrollably divide and ultimately conquer the host, remarkably similar to our early ancestors - the bacteria. In addition to the central role in early carcinogenic events, further dysregulation of apoptotic signaling cascades is strongly implicated in phenomenon of multi-drug resistance. If Warburg was correct, and mitochondrial dysregulation is a defining feature of cancer, as supported by autonomy via apoptosis inactivation (gain of function), is there a molecular rationale (i.e. signaling link) to apparent loss of function via reliance on net-energy inefficient glycolysis amidst massive energy needs? This was a central question preoccupying most of the cerebral bandwidths of a young graduate student, yours truly, embarking onto his $\mathrm{PhD}$ journey. What experimental model could shed light on the link? Enter Chromium (VI).

\subsection{Chromium exposure}

Hexavalent chromium [Cr(VI)] compounds are known environmental contaminants and human occupational respiratory carcinogens mostly originating from industrial processes (5). While the primary route of exposure is inhalation, additional modes include oral ingestion via contaminated water, or by direct dermal contact with products manufactured using chromium (6). The environmental release of chromium is estimated at over $90,000,000$ pounds annually (7). For example, the burning of one cigarette releases up to $0.5 \mu \mathrm{g}$ of chromium. It is estimated that the atmospheric concentration of particulate chromates in rural or residential areas of the U.S. ranges from 0.2 to $9 \mathrm{ng} / \mathrm{m}^{3}(7)$. In urban areas, especially in areas with a ferrochrome industry presence, those concentrations can easily be 10-100 fold higher (8). If one assumes that an 
urban dweller in a city with a ferrochrome production facility receives an inhalation exposure of $20 \mathrm{~m}^{3}$ per day of $90 \mathrm{ng} / \mathrm{m}^{3}$, then the daily lung intake is 1.8 $\mu \mathrm{g} /$ day. Epidemiological studies carried out in the U.K., Europe, Japan and the U.S. have consistently shown that workers in occupations where particulate chromates are generated or used have an elevated risk of respiratory disease including lung cancer $(9,10)$. Chromate workers have been found to have marked lung burdens of chromium with lung concentrations up to and exceeding 10,000 $\mu \mathrm{g}$ chromium per $100 \mathrm{~g}$ wet weight $(11,12)$. Taken together, extensive studies and data collection on the industrial and environmental exposure to chromium compounds have led the National Institute of Occupational Safety and Health $(\mathrm{NIOSH})$ to list chromate compounds as one of the major causes of occupational lung cancer, and the U.S. Environmental Protection Agency (U.S. EPA) and the International Agency for Research on Cancer (IARC) to classify chromium as a human carcinogen, currently making $\mathrm{Cr}(\mathrm{VI})$ one of 33 compounds listed to pose the greatest potential health threat in urban areas $(6,13-15)$.

\subsection{Chromium metabolism}

Chromium is a transition-group metal that has several oxidation states (6). Under physiological $\mathrm{pH}$ and temperature, $\mathrm{Cr}(\mathrm{VI})$ is unable to interact with $\mathrm{DNA}$ and lacks genotoxic activity (20). The structural similarity of chromates to physiological sulfates and phosphate ions, enables molecular mimicry and easy entry of $\mathrm{Cr}(\mathrm{VI})$ into cells through non-specific anion channels (Fig. 3) $(19,21)$. $\mathrm{Cr}(\mathrm{VI})$ enters the cell as an oxyanion followed by its metabolic reduction to $\mathrm{Cr}(\mathrm{V})$, $\mathrm{Cr}(\mathrm{IV})$, and to the final reduced trivalent (III) form. These reduced forms have been shown to induce a wide range of genomic DNA damage, which may lead to DNA replication inhibition (22). At physiological $\mathrm{pH}$, intracellular reduction is facilitated by several molecules/compounds such as ascorbate, glutathione (GSH), cysteine, lipoic acid, hydrogen peroxide, $N A D(P) H$, fructose and ribose $(16,18-20,23)$. The respective cellular availability and reaction rate with $\mathrm{Cr}(\mathrm{VI})$ determines which is the primary reducing agent. GSH, which is highly abundant 
intracellularly and found at millimolar concentrations, has been identified as a modulator of cell stress induced by $\mathrm{Cr}(\mathrm{VI})$ cytotoxicity. Upon $\mathrm{GSH}$ depletion, $\mathrm{Cr}(\mathrm{VI})$ induces an overexpression of heme-oxygenase 1 in human dermal fibroblasts, which has been used as a marker for $\mathrm{Cr}(\mathrm{VI})$-induced cell stress and cytotoxicity (24). The final product of chromate reduction, $\mathrm{Cr}$ (III), is biologically stable and has a greater DNA binding efficiency than that of $\mathrm{Cr}(\mathrm{VI})(16)$. Notably, extracellular reduction of $\mathrm{Cr}(\mathrm{VI})$ to $\mathrm{Cr}(\mathrm{III})$ detoxifies the molecule due to the inability of $\mathrm{Cr}(\mathrm{III})$ to cross the cellular membrane. However, when $\mathrm{Cr}(\mathrm{VI})$ is reduced in the cell to $\mathrm{Cr}(\mathrm{III})$, the weak membrane permeability of the trivalent form intracellularly traps the molecule, enabling the formation of stable $\mathrm{Cr}(\mathrm{III})$ complexes with proteins and nucleic acids leading to a large spectrum of DNA damage (19).

\subsection{Chromium-induced oxidative stress}

The reduction of $\mathrm{Cr}(\mathrm{VI})$ has been shown to yield reactive species such as free radicals, superoxide anions and hydroxyl radicals, possibly through Fenton-like reactions of $\mathrm{Cr}(\mathrm{V})$ and $\mathrm{Cr}(\mathrm{IV})$ with hydrogen peroxide $(18,25)$. Several electron spin resonance (ESR) spin trapping studies have shown the generation of hydroxyl radicals in conjunction with long-lived $\mathrm{Cr}(\mathrm{V})$ species, following the reduction of $\mathrm{Cr}(\mathrm{VI})$ by NADPH and glutathione (25-35). While the direct relationship between DNA-reactive oxygen species and chromium-induced DNA damage is heavily debated and unclear, there have been several studies supporting the role of ROS in $\mathrm{Cr}(\mathrm{VI})$-induced genotoxicity, cytotoxicity, and oxidative stress $(17,35-39)$. To date, many studies have attempted to investigate the complexities of $\mathrm{Cr}(\mathrm{VI})$-mediated oxidative stress and damage. Sugiyama et al. have shown $\mathrm{Cr}(\mathrm{VI})$ can be reduced to $\mathrm{Cr}(\mathrm{V})$ in the presence of vitamin $\mathrm{B} 2$ (riboflavin) in Chinese hamster V79 cells, leading to an increase in hydroxyl radicals, chromosomal aberrations and mutations at the HGPRT locus $(37,40)$. Moreover, when pretreated with flavin adenine dinucleotide or vitamin E (a free radical scavenger), there was a marked decrease in $\mathrm{Cr}(\mathrm{VI})$-induced single-strand 
breaks and cytotoxicity (41). Other in vitro studies have shown that antioxidant regulation may be dependent on the concentration of $\mathrm{Cr}(\mathrm{VI})$. Asatiani et al. demonstrated in human epithelial like L-41 cells and fetal human lung fibroblasts, that toxic $\mathrm{Cr}(\mathrm{VI})$ concentrations $(20 \mu \mathrm{M})$ lead to an increase in ROS, and a significant reduction in catalase, glutathione, and cytosolic $\mathrm{Cu} / \mathrm{Zn}$ superoxide dismutase activity (42). In contrast, there was a marked increase in catalase and glutathione peroxidase activity following non-toxic doses of $\mathrm{Cr}(\mathrm{VI})(2 \mu \mathrm{M})$, demonstrating the existence of thresholds to $\mathrm{Cr}(\mathrm{VI})$-induced oxidative stress. Furthermore, many reports studying $\mathrm{Cr}(\mathrm{VI})$-mediated oxidative stress investigate its effect on cell death, or apoptosis. A study by Shi et al. suggests that ROS contributes to the early effects of $\mathrm{Cr}(\mathrm{VI})$-induced apoptosis via a p53-independent mechanism, whereas the apoptotic effects could be blocked in the presence of ROS scavengers, such as catalase, aspirin and $\mathrm{N}$-acetyl-I-cysteine (35). Bagchi et al. have also shown an increase in ROS production that correlates with apoptotic death in a $\mathrm{Cr}(\mathrm{VI})$ concentration and dose-dependent fashion (43). Although there are many studies reporting on the relationship between oxidative stress and $\mathrm{Cr}(\mathrm{VI})$-mediated cytotoxicity, genotoxicity, and potential carcinogenesis, due to non-uniform treatment protocols, conflicting data and controversial methods used for detection of $\mathrm{Cr}(\mathrm{VI})$-induced oxidative stress, this relationship remains unclear. Martin et al. demonstrated that the high valence chromium species, bis(2-ethyl-2hydroxybutyrato) oxochromate (V) [Cr(V)-EHBA], was able to independently induce the fluorescence of two dyes commonly used to detect ROS (2,7-dichlorofluorescin and dihydrorhodamine) in A549 cells, which was not affected by treatment with radical scavengers (44). These data suggest that 2,7-dichlorofluorescin and dihydrorhodamine are more suitable for the qualitative detection of $\mathrm{Cr}(\mathrm{V})$, rather than ROS production in the presence of $\mathrm{Cr}(\mathrm{VI})$. Moreover, it is likely that any discussion on the potential role of $\mathrm{Cr}(\mathrm{VI})$ induced oxidative stress needs to include careful consideration of total dose over time and dose rate, as well as the relative ratios and availability of intracellular reductants and anti-oxidants. Given the intricate and unclear relationship between apoptosis and oxidative stress, it will be very difficult to determine 


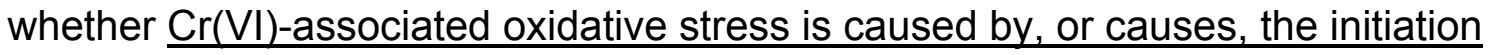
of apoptosis.

\section{5. $\mathrm{Cr}(\mathrm{VI})$-induced DNA damage and mutagenesis}

Chromium-induced DNA damage is thought to be the primary mechanism of chromate genotoxicity and mutagenicity, but it is only clearly observed at doses that are also capable of producing cell death (45). Recently, data has been presented to the EPA's Cancer Assessment Review Committee (CARC) to support mutagenicity as the initiating step in $\mathrm{Cr}(\mathrm{VI})$-induced carcinogenesis (46). Structural genetic lesions produced by $\mathrm{Cr}(\mathrm{VI})$ include DNA adducts, DNA-strand breaks, DNA-protein crosslinks, oxidized bases, abasic sites, and DNA interand intrastrand crosslinks $(20,47)$. The association of chromium with the phosphodiester backbone of DNA (chromium-DNA adduct) is one of the most abundant genetic lesions induced by chromium in mammalian cells and is thought to be a primary cause of $\mathrm{Cr}(\mathrm{VI})$ mutagenicity (19). $\mathrm{Cr}(\mathrm{III})$-ligand-DNA complexes form binary and ternary adducts, the latter of which are predominant and more toxicologically relevant $(19,20)$. There are four types of ternary adducts that primarily persist following $\mathrm{Cr}(\mathrm{VI})$ exposure and intracellular reduction; they are $\mathrm{Cr}(\mathrm{III})$-ascorbate-, $\mathrm{Cr}(\mathrm{III})$-cysteine-, $\mathrm{Cr}(\mathrm{III})$-histadine-, and $\mathrm{Cr}(\mathrm{III})-$ glutathione-DNA adducts, respectively (19).

Mutational analysis studies using SV-40 immortalized human fibroblasts transfected with plasmids extracellularly treated with $\mathrm{Cr}(\mathrm{VI})$, showed that the primary and most mutagenic adduct formed was ternary in nature, and that the $\mathrm{Cr}$ (III)-cysteine-DNA and $\mathrm{Cr}(\mathrm{III})$-ascorbate-DNA adducts were more mutagenic than the binary adducts $(48,49)$. O'Brien et al. showed significant DNA damage in the form of DNA-chromium-DNA crosslinks and DNA-chromium-GSH crosslinks following treatment of DNA with $\mathrm{Cr}(\mathrm{III})$ and $\mathrm{Cr}(\mathrm{VI})$ with ascorbate and $\mathrm{GSH}$, respectively (22). The damage induced by $\mathrm{Cr}(\mathrm{VI})$ can lead to dysfunctional DNA replication and transcription causing base substitutions and deletions 
serving as substrates for base excision repair (BER) and nucleotide excision repair (NER), and promoting genomic instability (50). Genomic instability, which can be caused by aberrant cell cycle checkpoints and dysregulated DNA repair mechanisms via microsatellite instability (MIN), plays an important role in $\mathrm{Cr}(\mathrm{VI})$ carcinogenesis (48). There are several lines of evidence suggesting the importance of base substitutions in $\mathrm{Cr}(\mathrm{VI})$ mutagenicity, with $\mathrm{G}: \mathrm{C}$ substitutions shown to be the primary target in vitro and in vivo; however, studies supporting the relevance of specific $\mathrm{Cr}(\mathrm{VI})$-induced base deletions are inconsistent (48). Furthermore, mechanistic studies in $\mathrm{Cr}(\mathrm{VI})$-induced toxicity and mutagenesis are lacking a focal point of mitochondria. 


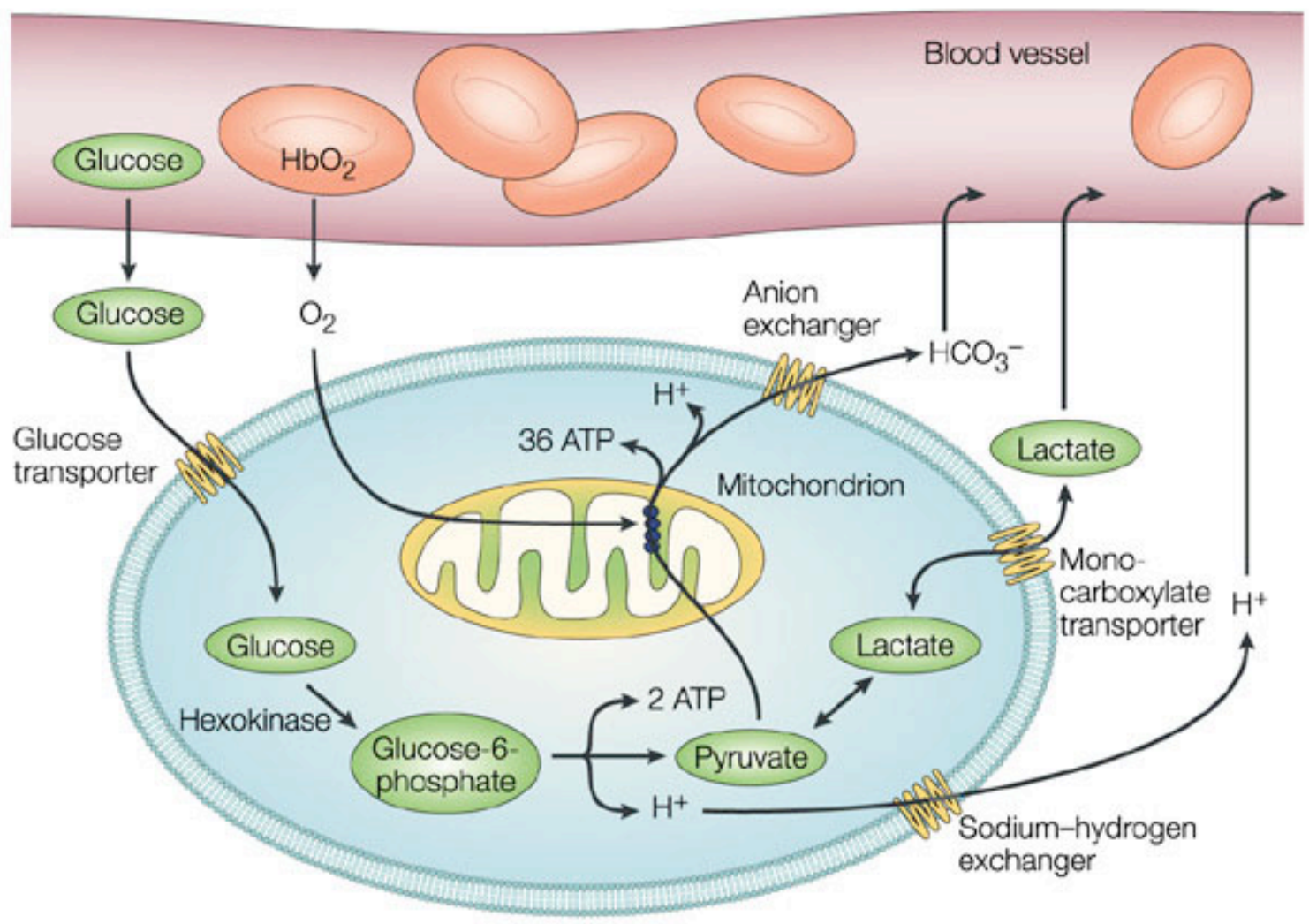

FIGURE 1. Schematic Representation of Cellular Energy Metabolism. 


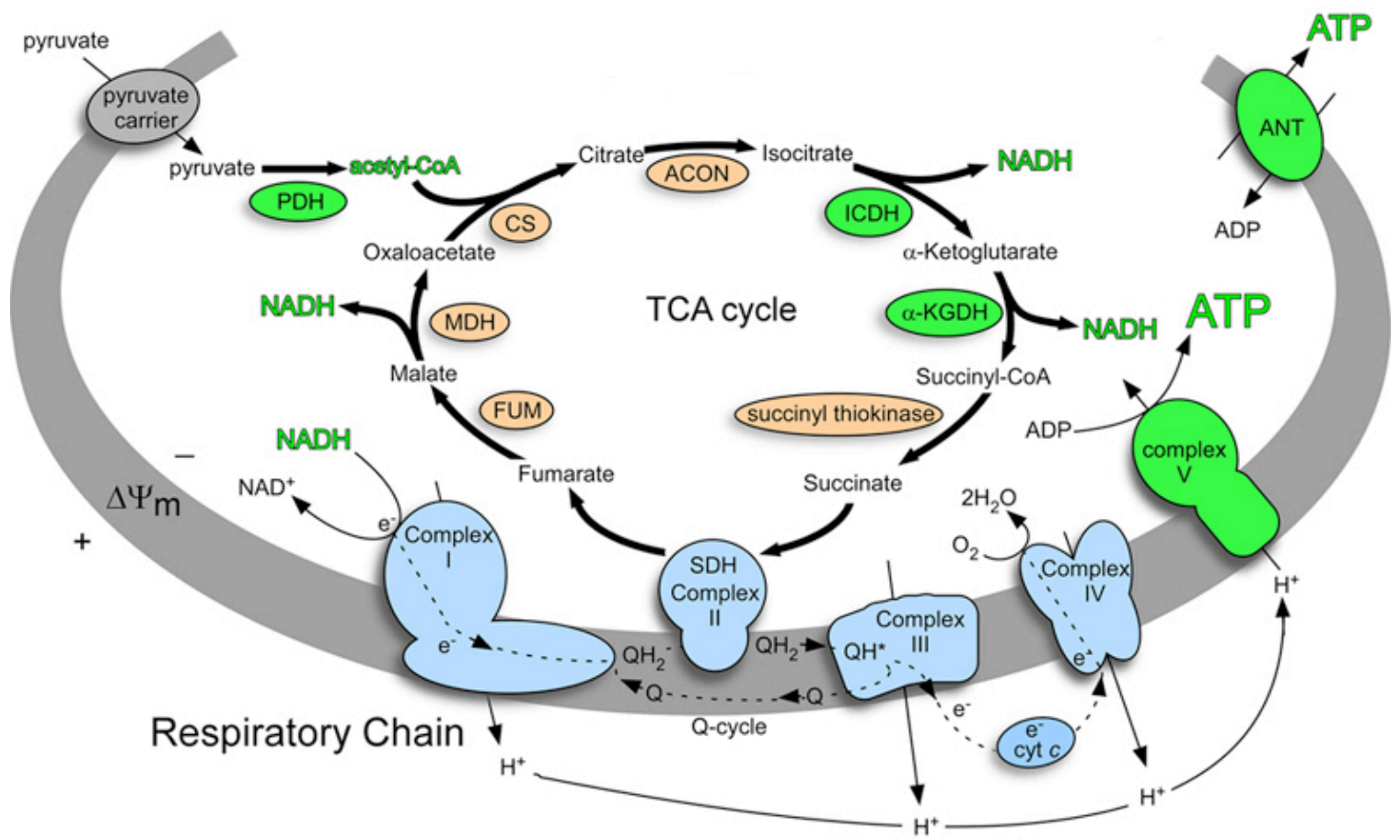

FIGURE 2. Diagrammatic Illustration of Oxidative Phosphorylation Pathway. 

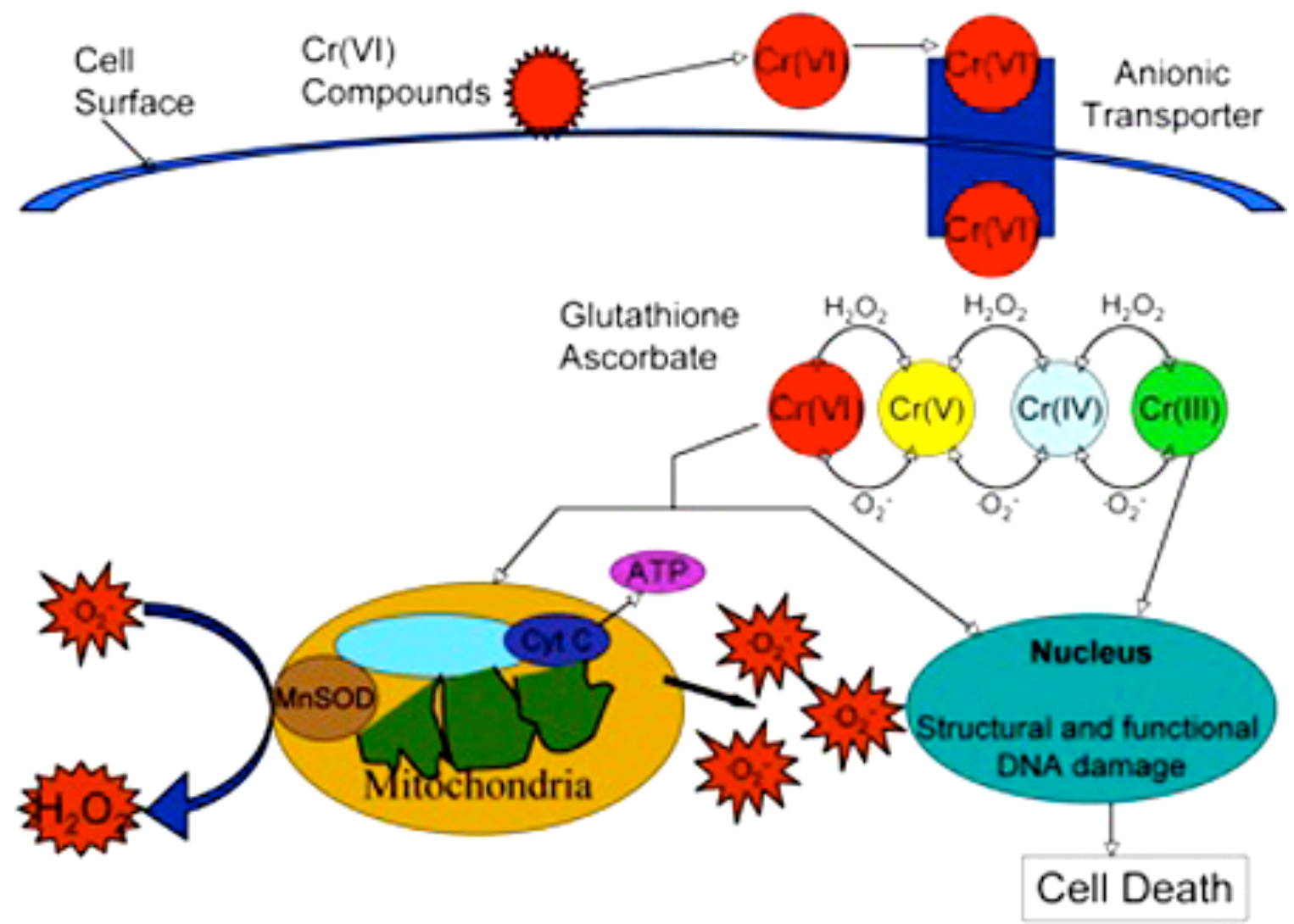

FIGURE 3. Schematic representation of known cellular reduction and cytotoxic effects of $\mathrm{Cr}(\mathrm{VI})$. 


\subsection{Summary}

A. Sustained environmental exposure to $\mathrm{Cr}(\mathrm{VI})$ compounds leads to a multitude of respiratory illnesses including lung cancer. Lung cancers mostly manifests as epithelial cell derived carcinomas. The process by which chromium is able to induce neoplastic progression is both complex and fairly elusive. Data can be found on each end of the spectrum, either supporting or refuting the many mechanisms proposed in the involvement of $\mathrm{Cr}(\mathrm{VI})$ carcinogenesis. Given phenotypic tissue diversity and considerable controversy surrounding observations on $\mathrm{Cr}(\mathrm{VI})$-mediated toxicity and mutagenesis, it is still unknown whether, and to what extent, human lung epithelial cells are susceptible to $\mathrm{Cr}(\mathrm{VI})$ induced toxicity and carcinogenesis. This is largely due to the lack of an appropriate model system to study the molecular mechanisms involved in $\operatorname{Cr}(\mathrm{VI})$ induced malignant transformation and carcinogenesis.

B. It is well established that the spectrum of cellular effects of $\mathrm{Cr}(\mathrm{VI})$ begins with its intracellular metabolism, reactive oxygen species production, formation of $\mathrm{Cr}$ DNA adducts, genomic damage, and alteration of survival signaling pathways. The causal early mechanistic events are accepted to be 'chemical' in nature, a function of $\mathrm{Cr}$ and $\mathrm{O}_{2}$ chemistry. It is of no surprise therefore that little is known about the role of mitochondrial physiology in cell's ultimate fate.

C. Mitochondria lie at the center of two cellular processes fundamental to evolution and maintenance of neoplasia - energy production and apoptosis. The potential causal relationship between the two processes has proven to be elusive despite rigorous scientific pursuit for almost 2 decades. The Warburg Paradox remains one of the central questions in molecular cancer research. 


\subsection{Specific Aims}

Although $\mathrm{Cr}(\mathrm{VI})$ is an established human carcinogen, its mechanism of action remains unclear. The overall objective of this study was to determine the molecular mechanisms of $\mathrm{Cr}(\mathrm{VI})$-induced apoptosis and malignant transformation with the goal of improving our understanding on $\mathrm{Cr}(\mathrm{VI})$-induced carcinogenesis. To achieve this goal we accomplished the following specific aims:

Aim I: Establish a lung cancer relevant model to study the mechanisms of $\mathrm{Cr}(\mathrm{VI})$ induced toxicity and carcinogenesis.

Aim II: Identify molecular effectors underlying the cellular response to $\operatorname{Cr}(\mathrm{VI})$ induced stress with the focal point of mitochondria.

Aim III: Deduce experimental basis for reconciliation of the Warburg Paradox. 


\subsection{References}

1. Dang, C. V., and Semenza, G. L. Oncogenic alterations of metabolism. Trends Biochem. Sci., 24 (1999) 68-72.

2. Semenza, G. L., Artemov, D., Bedi, A., Bhujwalla, Z., Chiles, K., Feldser, D., Laughner, E., Ravi, R., Simons, J., Taghavi, P., and Zhong, H. The metabolism of tumours: 70 years later. Novartis Found. Symp., 240 (2001) 251-260.

3. Ziegler, A., von Kienlin, M., Decorps, M., and Remy, C. High glycolytic activity in rat glioma demonstrated in vivo by correlation peak $1 \mathrm{H}$ magnetic resonance imaging. Cancer Res., 61,2001, 5595-5600.

4. Warburg, O. The Metabolism of Tumors. pp. 254-270. London: Arnold Constable, 1930.

5. Chromium, nickel and welding, IARC Monogr. Eval. Carcinog. Risks Hum. 49 (1990) 1-648.

6. National Toxicology Program, NTP 11th Report on Carcinogens, Rep. Carcinog.,no. 11, (2005), 1-A32.

7. National Safety Council, National Overview of 1998 Toxics Release Inventory, 1998.

8. Y. Ishikawa, K. Nakagawa, Y. Satoh, T. Kitagawa, H. Sugano, T. Hirano, E. Tsuchiya, "Hot spots" of chromium accumulation at bifurcations of chromate workers' bronchi, Cancer Res. 54 (1994) 2342-2346.

9. E.R. Plunkett, Handbook of Industrial Toxicology, Chemical Publishing, New York, NY, 1976.

10. M.O. Amdur, J. Doull, Cassarett and Doull's Toxicology, fourth ed., MaxwellMacMillan-Pergamon, New York, NY, 1991.

11. A.N. Uddin, F.J. Burns, T.G. Rossman, H. Chen, T. Kluz, M. Costa, Dietary chromium and nickel enhance UV-carcinogenesis in skin of hairless mice, Toxicol. Appl. Pharmacol. 221 (2007) 329-338.

12. J. Singh, D.E. Pritchard, D.L. Carlisle, J.A. Mclean, A. Montaser, J.M. Orenstein, S.R. Patierno, Internalization of carcinogenic lead chromate 
particles by cultured normal human lung epithelial cells: formation of intracellular lead-inclusion bodies and induction of apoptosis, Toxicol. Appl. Pharmacol. 161 (1999) 240-248.

13. Agency for Toxic Substances and Disease Registry (ATSDR), Toxicological profile for Polychlorinated Biphenyls (PCBs), 2000.

14. U.S. Department of Labor, Occupational Safety \& Health Administration, Contract No. J-9-F-0030, 2006.

15. U.S. Environmental Protection Agency, Integrated Risk Information System on Chromium (VI), 1999.

16. S. De Flora, Threshold mechanisms and site specificity in chromium(VI) carcinogenesis, Carcinogenesis 21 (2000) 533-541.

17. D. Bagchi, P.J. Vuchetich, M. Bagchi, E.A. Hassoun, M.X. Tran, L. Tang, S.J. Stohs, Induction of oxidative stress by chronic administration of sodium dichromate [chromium VI] and cadmium chloride [cadmium II] to rats, Free Radic. Biol. Med. 22 (1997) 471-478.

18. R.M. Sedman, J. Beaumont, T.A. McDonald, S. Reynolds, G. Krowech, R. Howd, Review of the evidence regarding the carcinogenicity of hexavalent chromium in drinking water, J. Environ. Sci. Health. C. Environ. Carcinog. Ecotoxicol. Rev. 24 (2006) 155-182.

19. K. Salnikow, A. Zhitkovich, Genetic and epigenetic mechanisms in metal carcinogenesis and cocarcinogenesis: nickel, arsenic, and chromium, Chem. Res. Toxicol. 21 (2008) 28-44.

20. T.J. O'Brien, S. Ceryak, S.R. Patierno, Complexities of chromium carcinogenesis: role of cellular response, repair and recovery mechanisms, Mutat. Res. 533 (2003) 3-36.

21. J. Alexander, J. Aaseth, Uptake of chromate in human red blood cells and isolated rat liver cells: the role of the anion carrier, Analyst 120 (1995) 931933.

22. T. O'Brien, J. Xu, S.R. Patierno, Effects of glutathione on chromium-induced DNA crosslinking and DNA polymerase arrest, Mol. Cell. Biochem. 222 (2001) 173-182. 
23. M. Ding, $\mathrm{X}$. Shi, Molecular mechanisms of $\mathrm{Cr}(\mathrm{VI})$-induced carcinogenesis, Mol. Cell. Biochem. 234-235 (2002) 293-300.

24. P. Joseph, Q. He, C. Umbright, Heme-oxygenase 1 gene expression is a marker for hexavalent chromium-induced stress and toxicity in human dermal fibroblasts, Toxicol. Sci. 103 (2008) 325-334.

25. K.W. Jennette, Microsomal reduction of the carcinogen chromate produces chromium (V), J. Am. Chem. Soc. (1982) 874.

26. S. Kawanishi, S. Inoue, S. Sano,MechanismofDNAcleavage induced by sodium chromate $(\mathrm{VI})$ in the presence of hydrogen peroxide, J. Biol. Chem. 261 (1986) 5952-5958.

27. X. Shi, N.S. Dalal, Generation of hydroxyl radical by chromate in biologically relevant systems: role of $\mathrm{Cr}(\mathrm{V})$ complexes versus tetraperoxochromate $(\mathrm{V})$, Environ. Health Perspect. 102 (Suppl. 3) (1994) 231-236.

28. X. Shi, Z. Dong, N.S. Dalal, P.M. Gannett, Chromate-mediated free radical generation from cysteine, penicillamine, hydrogen peroxide, and lipid hydroperoxides, Biochim. Biophys. Acta 1226 (1994) 65-72.

29. X.L. Shi, N.S. Dalal, The role of superoxide radical in chromium (VI)generated hydroxyl radical: the $\mathrm{Cr}(\mathrm{VI})$ Haber-Weiss cycle, Arch. Biochem. Biophys. 292 (1992) 323-327.

30. X.L. Shi, N.S. Dalal, ESR spin trapping detection of hydroxyl radicals in the reactions of $\mathrm{Cr}(\mathrm{V})$ complexes with hydrogen peroxide, Free Radic. Res. Commun. 10 (1990) 17-26.

31. X.L. Shi, N.S. Dalal, Evidence for a Fenton-type mechanism for the generation of $\mathrm{OH}$ radicals in the reduction of $\mathrm{Cr}(\mathrm{VI})$ in cellular media, Arch. Biochem. Biophys. 281 (1990) 90-95.

32. X.L. Shi, N.S. Dalal, One-electron reduction of chromate by NADPHdependent glutathione reductase, J. Inorg. Biochem. 40 (1990) 1-12.

33. X.L. Shi, N.S. Dalal, Chromium (V) and hydroxyl radical formation during the glutathione reductase-catalyzed reduction of chromium (VI), Biochem. Biophys. Res. Commun. 163 (1989) 627-634. 
34. X.L. Shi, N.S. Dalal, V. Vallyathan, One-electron reduction of carcinogen chromate by microsomes, mitochondria, and Escherichia coli: identification of $\mathrm{Cr}(\mathrm{V})$ and OH radical, Arch. Biochem. Biophys. 290 (1991) 381-386.

35. X. Shi, A. Chiu, C.T. Chen, B. Halliwell, V. Castranova, V. Vallyathan, Reduction of chromium $(\mathrm{VI})$ and its relationship to carcinogenesis, J. Toxicol. Environ. Health B Crit. Rev. 2 (1999) 87-104.

36. A.K. Patlolla, C. Barnes, D. Hackett, P.B. Tchounwou, Potassium dichromate induced cytotoxicity, genotoxicity and oxidative stress in human liver carcinoma (HepG2) cells, Int. J. Environ. Res. Publ. Health 6 (2009) 643-653.

37. M. Sugiyama, K. Tsuzuki, X. Lin, M. Costa, Potentiation of sodium chromate( $\mathrm{VI})$-induced chromosomal aberrations and mutation by vitamin $\mathrm{B} 2$ in Chinese hamster V79 cells, Mutat. Res. 283 (1992) 211-214.

38. N. Azad, A.K. Iyer, A. Manosroi, L. Wang, Y. Rojanasakul, Superoxidemediated proteasomal degradation of $\mathrm{Bcl}-2$ determines cell susceptibility to $\mathrm{Cr}(\mathrm{VI})$-induced apoptosis, Carcinogenesis 29 (2008) 1538-1545.

39. N. Azad, A.K. lyer, L. Wang, Y. Lu, D. Medan, V. Castranova, Y. Rojanasakul, Nitric oxide-mediated Bcl-2 stabilization potentiates malignant transformation of human lung epithelial cells, Am. J. Respir. Cell Mol. Biol. (2009).

40 M. Sugiyama, Effects of vitamins on chromium(VI)-induced damage, Environ. Health Perspect. 92 (1991) 63-70.

41. M. Sugiyama, Effects of vitamin $E$ and vitamin $B 2$ on chromate-induced DNA lesions, Biol. Trace Elem. Res. 21 (1989) 399-404.

42. N. Asatiani, N. Sapojnikova, M. Abuladze, T. Kartvelishvili, N. Kulikova, E. Kiziria, E. Namchevadze, H.Y. Holman, Effects of $\mathrm{Cr}(\mathrm{VI})$ long-term and low dose action on mammalian antioxidant enzymes (an in vitro study), J. Inorg. Biochem. 98 (2004) 490-496.

43. D. Bagchi, M. Bagchi, S.J. Stohs, Chromium (VI)-induced oxidative stress, apoptotic cell death and modulation of p53 tumor suppressor gene, Mol. Cell. Biochem. 222 (2001) 149-158. 
44. B.D. Martin, J.A. Schoenhard, K.D. Sugden, Hypervalent chromium mimics reactive oxygen species as measured by the oxidant-sensitive dyes 2,7dichlorofluorescin and dihydrorhodamine, Chem. Res. Toxicol. 11 (1998) 1402-1410.

45. S.R. Patierno, D. Banh, J.R. Landolph, Transformation of $\mathrm{C} 3 \mathrm{H} / 10 \mathrm{~T} 1 / 2$ mouse embryo cells to focus formation and anchorage independence by insolublelead chromate but not soluble calcium chromate: relationship to mutagenesis and internalization of lead chromate particles, Cancer Res. 48 (1988) 5280-5288.

46. N. McCarroll, N. Keshava, J. Chen, G. Akerman, A. Kligerman, E. Rinde, An evaluation of the mode of action framework for mutagenic carcinogens case study II: chromium (VI), Environ. Mol. Mutagen. (2009).

47. S. Ceryak, C. Zingariello, T. O'Brien, S.R. Patierno, Induction of pro-apoptotic and cell cycle-inhibiting genes in chromium (VI)-treated human lung fibroblasts: lack of effect of ERK, Mol. Cell. Biochem. 255 (2004) 139-149.

48. A.L. Holmes, S.S. Wise, S. Wise JP, Carcinogenicity of hexavalent chromium, Indian J. Med. Res. 128 (2008) 353-372.

49. A. Zhitkovich, Y. Song, G. Quievryn, V. Voitkun, Non-oxidative mechanisms are responsible for the induction of mutagenesis by reduction of $\mathrm{Cr}(\mathrm{VI})$ with cysteine: role of ternary DNA adducts in $\mathrm{Cr}(\mathrm{III})$-dependent mutagenesis, Biochemistry 40 (2001) 549-560.

50. T.J. O'Brien, P. Witcher, B. Brooks, S.R. Patierno, DNA polymerase zeta is essential for hexavalent chromium-induced mutagenesis, Mutat. Res. 663 (2009) 77-83 


\section{CHAPTER II}

Energy Substrate Modulates $\mathrm{Cr}(\mathrm{VI})$-Induced Apoptosis

Differentially in Cancerous vs. Non-Cancerous cells via a

Mitochondrial Reactive Oxygen Species-Dependent Mechanism 


\subsection{Abstract}

$\mathrm{Cr}(\mathrm{VI})$ compounds are redox cycling carcinogens that induce apoptosis as a primary mode of cell death. Since defects in apoptosis regulatory mechanisms are considered to be indispensable foundation of carcinogenesis it is critical to understand the molecular effectors involved. Cellular energy powerhouses, the mitochondria, house the molecular effectors involved in signaling cascades comprising commitment to apoptosis and are reported to be dysregulated in a variety of tumors. The objective of this study was to characterize the key signaling effectors in $\mathrm{Cr}(\mathrm{VI})$-induced apoptosis and determine the relationship between those effectors and mode of cellular energy production in cancerous vs. non-cancerous cells. Our data show that $\mathrm{Cr}(\mathrm{VI})$ induces mitochondrial ROS dependent apoptosis in human lung cancer (H460) and non-cancer (BEAS-2B) cells. The intensity of mitochondrial ROS production and consequently apoptosis is highly dependent on the energy substrate available to the cells. Forcing of oxidative phosphorylation-only energy metabolism abrogates native 4-fold apoptosis resistance in cancerous $\mathrm{H} 460$ cells vs. non-cancerous BEAS-2B cells. Collectively, our report presents a mechanistic advancement in the understanding of molecular effectors underlying the Warburg's "mitochondrial dysregulation" hypothesis and puts mitochondrial ROS as key mediators of the commitment phase of programmed cell death in a model of $\mathrm{Cr}(\mathrm{VI})$-induced toxicity. 


\subsection{Introduction}

Mitochondria play an essential role in providing energy to the eukaryotic cell. In recent years, mitochondria have become a central subject of study because of their role as sensors and executioners of apoptosis (1-3). Apoptosis is an energy-dependent, genetically encoded program for cell death that is indispensable for the normal development of the organism (4). Alterations in the cellular program of apoptosis contribute to the progression of various human pathologies, including cancer and neurodegenerative diseases $(5,6)$. The study of the energy metabolism of cancer cells was a central issue of cancer research until the era of molecular biology. As early as 1930, Otto Warburg proposed the hypothesis that cancer cells may have impaired mitochondrial function and that this alteration would result in the elevated rate of glycolysis that is a common feature of most tumors (7). Although the glycolytic phenotype of many cancer cells and tumors has been demonstrated at both the biochemical and molecular levels $(8-10)$, the presumed impairment of mitochondrial function was never established in cancer biology (11). Differences in the number of mitochondria (12), their ultrastructure $(13,14)$, the content and composition in all OXPHOS complexes $(12,15-18)$, respiratory chain activity $(18,19)$, the expression of oxidative phosphorylation dependent genes (20), and levels of mitochondrial DNA (15) have all been variously reported by different investigators, but no consistent pattern has emerged. When glucose is no longer available, as can occur in solid tumors (21), cancer cells are forced to use alternative energy substrates such as the oxidation of glutamine, a process called glutaminolysis (22). This process requires an active oxidative phosphorylation for ATP production. Here, we have examined the physiological effects of such a change in substrate availability on a human lung cancer cell line (H460) vs. non-cancer cell line (BEAS-2B) in a model of $\mathrm{Cr}(\mathrm{VI})$-induced acute toxicity.

Inhalation of $\mathrm{Cr}(\mathrm{VI})$ compounds as dust particles and fumes is a common form of exposure that can cause multiple respiratory effects including lung cancer (23, 
24,25-28). More than 300,000 workers in the United States are potentially exposed to $\mathrm{Cr}(\mathrm{VI})$ and $\mathrm{Cr}(\mathrm{VI})$-containing compounds in the workplace. $\mathrm{Cr}(\mathrm{VI})$ enters cells through a non-specific anion transport system (29). Once inside, it is reduced by cellular reductants to its lower oxidation states, pentavalent chromium $(\mathrm{Cr}(\mathrm{V}))$ and tetravalent chromium $(\mathrm{Cr}(\mathrm{IV}))(30)$. The lower oxidation intermediates of chromium are reactive and lead to production of reactive oxygen species (ROS) $(31,32)$ which, in turn, cause various levels of oxidative damage including DNA strand breaks, base modification and lipid peroxidation (30, 33$37)$. Acute laboratory exposure generally results in cell death in the form of apoptosis (38) or mutagenesis (39) depending largely on $\mathrm{Cr}(\mathrm{VI})$ dose and the system used.

To date, specific molecular effectors constituting cellular response to acute $\mathrm{Cr}(\mathrm{VI})$ stress remain poorly understood, especially at the level of mitochondria.

Furthermore, the effect of energy substrate modulation (glycolysis vs. oxidative phosphorylation) has not been investigated in published $\mathrm{Cr}(\mathrm{VI})$ studies. Our study is the first comprehensive analysis of the effect energy substrate plays in $\mathrm{Cr}(\mathrm{VI})$ induced acute toxicity in cancerous vs. non-cancerous cells. We identify mitochondrial ROS as the primary agents of commitment phase of programmed cell death and establish their quantitative dependence on cellular energetic mode. Further, forcing of oxidative phosphorylation-only energy metabolism abrogates native 4-fold apoptosis resistance in human lung cancer $\mathrm{H} 460$ cells vs. their non-cancerous BEAS-2B counterparts. Collectively, our report presents a mechanistic advancement in understanding of molecular effectors underlying the Warburg's "mitochondrial dysregulation" hypothesis and establishes a model for further mechanistic studies of xeno-biotic toxicities. 


\subsection{Materials and Methods}

Chemicals and Reagents

$\mathrm{N}$-acetyl cysteine (NAC), rotenone, diphenylene iodonium (DPI), sodium

pyruvate, buthionene sulfoximine (BSO), Tris- $\mathrm{HCl}$, Triton $\mathrm{X}-100, \mathrm{NaCl}$, glycerol, $\mathrm{Na}_{3} \mathrm{VO}_{4}, \mathrm{NaF}$, phenylmethylsulfonyl fluoride (PMSF), bicinchoninic acid (BCA), 5,5-dimethyl-I-pyrroline $\mathrm{N}$-oxide (DMPO), monochlorobimane ( $\mathrm{mBCl}$ ), glucose and sodium dichromate $\left(\mathrm{Na}_{2} \mathrm{Cr}_{2} \mathrm{O}_{7} .2 \mathrm{H}_{2} \mathrm{O}\right)[\mathrm{Cr}(\mathrm{VI})]$ were obtained from Sigma Chemical Inc. (St. Louis, MO). The spin trap DMPO was purified by charcoal decolorization and vacuum distillation. DMPO solution, thus purified, did not contain any electron spin resonance (ESR)-detectable impurities. Phosphatebuffered saline (PBS) and RPMI-1640 medium were purchased from Gibco BRL (Gaithersburg, MD). Chelex 100 chelating resin was purchased from Bio-Rad Laboratories (Richmond, CA). The phosphate buffer $(\mathrm{pH} 7.4)$ was treated with Chelex 100 to remove transition metal ion contaminants. Hanks balanced salt solution (HBSS) was purchased from Mediatech (Herndon, VA). Defined fetal bovine serum (FBS) was purchased from Hyclone (Logan, UT). Apoptosis dye Hoechst 33342 was purchased from Molecular Probes (Eugene, OR). Antibodies for glutathione peroxidase, (GPx), manganese superoxide dismutase (MnSOD), $\mathrm{Bcl}-2$, peroxidase-labeled secondary antibodies, anti-myc agarose beads, and protein A-agarose were from Santa Cruz Biotechnology (Santa Cruz, CA). Transfecting agent Lipofectamine 2000 was from Invitrogen (Carlsbad, CA).

\section{Cell Culture}

The human lung bronchial epithelial BEAS-2B and human lung epithelial cancer H460 cell lines were obtained from the American Type Culture Collection (ATCC) (Rockville, MD). Cells were cultured in RPMI 1640 medium (Sigma, St. Louis, $\mathrm{MO}$ ) containing $5 \%$ fetal bovine serum, $2 \mathrm{mM} \mathrm{L-glutamine,} 100 \mathrm{units} / \mathrm{ml}$ penicillin and $100 \mu \mathrm{g} / \mathrm{ml}$ streptomycin in a $5 \% \mathrm{CO}_{2}$, standard atmosphere environment at $37^{\circ} \mathrm{C}$. Cells were passaged at preconfluent densities using a solution containing $0.05 \%$ trypsin and $0.5 \mathrm{mM}$ EDTA (Invitrogen). Energy substrate modulation 
studies were conducted in RPMI glucose-free medium containing $20 \mathrm{mM}$ pyruvate and $10 \mathrm{mM} \mathrm{L-glutamine.} \mathrm{The} \mathrm{control} \mathrm{media} \mathrm{contained} 20 \mathrm{mM}$ glucose instead of pyruvate. Cells were acclimated to the media at least $24 \mathrm{~h}$ prior to the commencement of the experiments.

\section{Apoptosis Assay}

After specific treatments, apoptosis was determined by incubating cells with 10 $\mu \mathrm{g} / \mathrm{ml}$ Hoechst 33342 nuclear stain for 30 min at $37^{\circ} \mathrm{C}$ and scoring the percentage of cells having intensely condensed chromatin and/or fragmented nuclei by fluorescence microscopy (Axiovert100, CarlZeiss) using Pixera software.

\section{Mitochondrial Membrane Potential $\left(\Delta \psi_{m}\right)$}

$\Delta \Psi_{\mathrm{m}}$ was estimated using $5,5^{\prime}, 6,6^{\prime}$-tetrachloro-1,1',3,3'-tetraethylbenzimidazole carbocyanide iodide (JC-1; Molecular Probes). JC-1 is a fluorescent compound (excitation maximum, $490 \mathrm{~nm}$ ) that exists as a monomer at low concentrations. At higher concentrations, JC-1 forms aggregates. Fluorescence of the monomer is green (emission, $527 \mathrm{~nm}$ ), whereas that of the $\mathrm{J}$ aggregate is red (emission, $590 \mathrm{~nm}$ ). Mitochondria with intact membrane potential (higher than $100 \mathrm{mV}$ ) concentrate JC-1 into aggregates that fluoresce red, whereas de-energized mitochondria cannot concentrate $\mathrm{JC}-1$ and fluoresce green. Cells were grown in $25-\mathrm{cm}^{2}$ dishes until $90 \%$ confluence and either kept in the medium alone (control) or treated with $1 \mathrm{mM} \mathrm{Cr}(\mathrm{VI})$ for $1 \mathrm{~h}$. Cells were washed with PBS and incubated at $37^{\circ} \mathrm{C}$ for $45 \mathrm{~min}$ with $6.5 \mathrm{mM} \mathrm{JC}-1$ in media in the dark. Cells were collected by trypsinization, washed in PBS, and resuspended in $500 \mathrm{ml}$ of PBS. The ratio of the reading at $590 \mathrm{~nm}$ to the reading at $527 \mathrm{~nm}$ (590:527 ratio) was considered as a relative $\Delta \psi_{\mathrm{m}}$ value.

\section{Stable Transfection}

Stable transfectants of glutathione peroxidase (GPx), manganese superoxide dismutase (MnSOD) and Bcl-2 were generated by culturing BEAS-2B and $\mathrm{H} 460$ 
cells in six-well plates until they reached $80 \%$ confluence. $1 \mu \mathrm{g}$ of cytomegalovirus -neo vector and $15 \mu \mathrm{l}$ of Lipofectamine 2000 reagent with $2 \mu \mathrm{g}$ of Bcl-2, GPx, MnSOD, or control pcDNA3 plasmid were used to transfect the cells in the absence of serum. After $10 \mathrm{~h}$, the medium was replaced with culture medium containing $5 \%$ fetal bovine serum. Approximately $36 \mathrm{~h}$ after the beginning of the transfection, the cells were digested with $0.03 \%$ trypsin, and the cell suspensions were plated onto $75 \mathrm{ml}$ culture flasks and cultured for 24 to 28 days with $\mathrm{G} 418$ selection $(400 \mu \mathrm{g} / \mathrm{ml})$. Stable transfectants were identified by Western blot analysis and were cultured in G418-free RPMI 1640 medium for at least two passages before each experiment.

\section{Electron Spin Resonance ROS Assay}

Spin trapping was used to detect short-lived free radical intermediates. This technique involved the addition-type reaction of a short-lived radical with a paramagnetic compound (spin trap) to form a relatively long-lived free radical product (spin adduct), which was then studied using conventional ESR. All ESR measurements were conducted using a Bruker EMX spectrometer (Bruker Instruments, Inc., Billerica, MA) and a flat cell assembly. The intensity of the signal was used to measure the amount of short-lived radicals trapped; the hyperfine couplings of the spin adduct were generally characteristic of the original trapped radicals. Hyperfine couplings were measured (to $0.1 \mathrm{G}$ ) directly from magnetic field separation using potassium tetraperoxochromate $\left(\mathrm{K}_{3} \mathrm{CrO}_{8}\right)$ and 1,1-diphenyl-2-picrylhydrazyl (DPPH) as reference standards. The relative radical concentration was estimated by multiplying half of the peak height by $[\Delta \mathrm{Hpp}]$, where $\Delta \mathrm{Hpp}$ represents peak-to-peak width. An Acquisit program was used for data acquisition and analysis. BEAS-2B or $\mathrm{H} 460$ cells were mixed with DMPO $(100 \mathrm{mM})$ and PBS to a final volume of $1 \mathrm{ml}$. The mixtures were then incubated for $5 \mathrm{~min}$ in a $37^{\circ} \mathrm{C}$ water bath. The reaction mixture was then transferred to a flat cell for ESR measurement. Experiments were performed at room temperature under ambient air. 


\section{Western Blotting}

After specific treatments, cells were incubated in lysis buffer containing $20 \mathrm{mM}$ Tris- $\mathrm{HCl}$ (pH 7.5), $1 \%$ Triton X-100, $150 \mathrm{mM} \mathrm{NaCl}, 10 \%$ glycerol, $1 \mathrm{mM} \mathrm{Na}_{3} \mathrm{VO}_{4}$, $50 \mathrm{mM} \mathrm{NaF}, 100 \mathrm{mM}$ phenylmethylsulfonyl fluoride (PMSF), and protease inhibitor mixture for $20 \mathrm{~min}$ on ice. After insoluble debris was precipitated by centrifugation at $14,000 \times \mathrm{g}$ for $15 \mathrm{~min}$ at $4^{\circ} \mathrm{C}$, the supernatants were collected and assayed for protein content using bicinchoninic acid (BCA) method. Equal amount of proteins per sample $(15 \mu \mathrm{g})$ were resolved on $10 \%$ SDS-PAGE and transferred onto a $0.45-\mu \mathrm{m}$ nitrocellulose membrane. The transferred membranes were blocked for $1 \mathrm{~h}$ in $5 \%$ non-fat dry milk in TBST $(25 \mathrm{mM}$ Tris- $\mathrm{HCl}, \mathrm{pH} 7.4$, $125 \mathrm{mM} \mathrm{NaCl}, 0.05 \%$ Tween 20 ) and incubated with the appropriate primary antibodies and horseradish peroxidase-conjugated secondary antibodies. The immune complexes were detected by chemiluminescence (Supersignal, West Pico; Pierce).

\section{Statistical Analysis}

The data were expressed as means $\pm S D$ of three or more independent experiments. Statistical analysis was performed using two-tailed and paired Student's t-test. $\mathrm{P}$ values less than 0.05 were considered statistically significant and indicated by an asterisk

\subsection{Results}

\section{Cr(VI)-Induced Cell Death}

$\mathrm{Cr}(\mathrm{VI})$ induces apoptosis as the primary mode of cell death during acute laboratory exposure (40). Dysregulation of apoptosis regulatory mechanisms is widely accepted to be one of the hallmarks of cancer (41). To characterize the apoptotic response to $\mathrm{Cr}(\mathrm{VI})$ treatment in our system, non-tumorigenic human bronchial epithelial (BEAS-2B) cells and human lung cancer ( $\mathrm{H} 460)$ cells were treated with different doses of $\mathrm{Cr}(\mathrm{VI})(0-50 \mu \mathrm{M})$ and apoptosis was determined after $12 \mathrm{~h}$ by an established Hoechst 33342 assay. Figs. $1, A$ and $B$, show that 
$\mathrm{Cr}(\mathrm{VI})$ treatment caused a dose dependent increase in cell apoptosis over control level, as indicated by increased nuclear fluorescence and chromatin condensation of the treated cells. Notably, human lung cancer H460 cells showed increased resistance to $\mathrm{Cr}(\mathrm{VI})$-induced apoptosis vs. their nontumorigenic counterparts. At $20 \mu \mathrm{M} \mathrm{Cr}(\mathrm{VI})$, an approximate $\mathrm{LD}_{50}$ for BEAS-2B, human lung cancer $\mathrm{H} 460$ cells exhibited approximately $10 \%$ apoptotic response.

\section{Energy Substrate Effect on Cr(VI)-Induced Cell Death}

Mitochondrial level signaling has been implicated in $\mathrm{Cr}(\mathrm{VI})$-induced apoptosis. Various reports suggest that mitochondria are dysregulated in cancer cells and that cancer cells prefer to synthesize energy via less net-energy efficient glycolysis as opposed to mitochondria-localized oxidative phosphorylation. Accordingly, the effect of energy substrate on $\mathrm{Cr}(\mathrm{VI})$-induced cell death was evaluated in BEAS-2B and $\mathrm{H} 460$ cell populations grown in glucose containing $(\mathrm{G}+\mathrm{P}-)$ or glucose lacking, pyruvate containing (G-P+) medium. Figs. 2, $A$ and $B$, show that energy substrate modulation significantly altered $\mathrm{Cr}(\mathrm{VI})$-induced toxicity profile in both, BEAS-2B and $\mathrm{H} 460$ cells. BEAS-2B cells became approximately $50 \%$ more sensitive to $\mathrm{Cr}(\mathrm{VI}) 20 \mu \mathrm{M}$ dose under energy substrate conditions forcing oxidative phosphorylation only metabolism. Notably, cancer H460 cells' sensitivity increased approximately $400 \%$ when oxidative phosphorylation was forced, resulting in approximately 8-fold increase in apoptosis and quantitative lethal dose normalization between the two cell types (Fig. 2C).

\section{Effect of $\mathrm{Cr}(\mathrm{VI})$ on ROS Generation}

Reactive oxygen species (ROS) have been strongly implicated in mechanism of $\mathrm{Cr}(\mathrm{VI})$-induced toxicity. We deployed ESR spin trapping to determine the identity and intensity of free radical generation in $\mathrm{Cr}(\mathrm{VI})$-stimulated BEAS-2B and $\mathrm{H} 460$ cells. Figs. 3A-B show the typical ESR spectra obtained from a mixture containing $10^{6} \mathrm{cells} / \mathrm{ml}, \mathrm{Cr}(\mathrm{VI})$ and $100 \mathrm{mM}$ spin trap (DMPO) in a phosphate buffer solution ( $\mathrm{pH}$ 7.4). The spectrum exhibits a 1:2:2:1 quartet with hyperfine 
splittings of $a_{H}=a_{N}=14.9 \mathrm{G}$, where $a_{H}$ and $a_{N}$ denote hyperfine splittings of $\beta$ hydrogen and nitroxy nitrogen, respectively. Based on these splitting constants (42), this quartet spectrum was assigned to $\mathrm{DMPO} / . \mathrm{OH}$ adduct, which is an indirect evidence for $\cdot \mathrm{OH}$ generation. Cells alone did not generate any observable ESR signal. The weak signal at the right side is $\mathrm{Cr}(\mathrm{V})$, which was generated during the $\mathrm{Cr}(\mathrm{VI})$ reduction by the cells. Figure $3 \mathrm{C}$ shows spectral intensity (amount of .OH radicals generated) in BEAS-2B vs. H460 cells. Notably, non-tumorigenic BEAS-2B cells showed significantly stronger radical generation then their cancer $\mathrm{H} 460$ counterparts across the $0.1-1 \mathrm{mM} \mathrm{Cr}(\mathrm{VI})$ range at $10 \mathrm{~min}$ post-treatment. Consistent with previously observed (43) inverse relationship between toxic stimuli initiated cellular ROS production and $\Delta \psi_{\mathrm{m}}$, we observed a dose dependent decrease of $\Delta \psi_{\mathrm{m}}$ in both cell lines (Fig. 3D) $2 \mathrm{~h}$ post $\mathrm{Cr}(\mathrm{VI})$ treatment. Notably, cancer $\mathrm{H} 460$ cells showed approximately $50 \%$ lower $\Delta \psi_{\mathrm{m}}$ as compared to non-tumorigenic BEAS-2B cells.

\section{Effect of Energy Substrate on Cr(VI)-Induced ROS Generation and $\Delta \psi_{m}$} ROS have been demonstrated to play a critical role in $\mathrm{Cr}(\mathrm{VI})$-induced cell death and are detected in our system. Their origin, however, is subject to considerable controversy. In order to determine the relative role of oxidative phosphorylation system on radical production in our model, we utilized ESR spectroscopy to determine qualitatively and quantitatively the effect of energy substrate on $\mathrm{Cr}(\mathrm{VI})$ induced radical production. Figs. 4A-B show 1:2:2:1 quartet with hyperfine splittings consistent with. $\mathrm{OH}$ production, under conditions favoring glycolysis and, those forcing oxidative phosphorylation, in both cell types. Notably, nontumorigenic BEAS-2B cells cultured in the medium with no glucose, showed no significant difference in spectral intensity whereas cancer $\mathrm{H} 460$ cells exhibited significantly different response to forced oxidative phosphorylation with approximately $40 \%$ increase in spectral intensity (Fig. 4C). Both cell lines exhibited a slight increase in $\Delta \psi_{\mathrm{m}}$ in glucose lacking medium (Fig. 4D). 
To establish a causal relationship between the observed radical production and apoptosis following the $\mathrm{Cr}(\mathrm{VI})$ insult, we turned to well established small molecule inhibitors and inducers of ROS. Figs. 5A-C suggest a causal role of ROS in $\mathrm{Cr}(\mathrm{VI})$-induced apoptosis. Pretreatment of the cells with L-buthionine-S, $R$ sulfoximine (BSO), an oxidative stress inducer (44), significantly increased the apoptotic effect of $\mathrm{Cr}(\mathrm{VI})$ in both BEAS-2B and $\mathrm{H} 460$ cells. Of interest, $\mathrm{H} 460$ apoptosis increased approximately $300 \%$ whereas BEAS-2B cells showed significant, but relatively marginal increase of $30 \%$. Pretreatment with $\mathrm{N}$-acetylcysteine (NAC), a widely accepted, broad spectrum antioxidant, resulted in a complete apoptosis shutdown with proportion of Hoechst 33342 positive cells returning to control levels in both cell types.

\section{Source of ROS Involved in Cr(VI)-Induced Apoptosis}

To assess the relative importance of mitochondrial vs. cytosolic ROS on $\mathrm{Cr}(\mathrm{VI})$ induced apoptosis, cells were treated with $\mathrm{Cr}(\mathrm{VI})$ in the presence or absence of diphenylene iodonium (DPI), a specific inhibitor of NADPH oxidase $(45,46)$, or rotenone, a mitochondrial electron transport chain interrupter $(47,48)$, and their effects on system apoptosis were examined. The results show that both rotenone and $\mathrm{DPI}$ reduced $\mathrm{Cr}(\mathrm{VI})$-induced apoptosis, with the effect of rotenone being much larger (Figs. 6, A-B). These results suggest that even though cytosolic ROS may be involved, mitochondrial oxidative phosphorylation chain seems to generate the majority of ROS involved in $\mathrm{Cr}(\mathrm{VI})$-induced apoptosis.

\section{Effect of Glutathione Peroxidase and Superoxide Dismutase on $\mathrm{Cr}(\mathrm{VI})$-Induced Apoptosis}

To confirm the role of mitochondrial ROS in $\mathrm{Cr}(\mathrm{VI})$-induced apoptosis by means of genetic manipulation, both cell types were stably transfected with endogenous antioxidant enzyme GPx, MnSOD, or control plasmid, and their effects on apoptosis were determined. GPx and MnSOD are the two primary enzymes charged with detoxifying ROS emanating from the electron transport chain of mitochondria and are localized in the mitochondrial matrix (49-52). Notably, 
apoptosis assay showed a significant decrease in apoptotic response to $\mathrm{Cr}(\mathrm{VI})$ treatment in GPx- and MnSOD-transfected cells but not in mock-transfected cells (Figs. 7A-C). These observations suggest that aside from the already established role of hydroxyl radical $(\cdot \mathrm{OH})$, hydrogen peroxide $\left(\mathrm{H}_{2} \mathrm{O}_{2}\right)$ and superoxide anion $\left(\cdot \mathrm{O}_{2}^{-}\right)$play critical roles in $\mathrm{Cr}(\mathrm{VI})$-induced apoptosis.

\section{Effect of Bcl-2 on $\mathrm{Cr}(\mathrm{VI})$-Induced Apoptosis}

To determine whether elevated mitochondrial ROS production represents a commitment point in $\mathrm{Cr}(\mathrm{VI})$-induced apoptosis, localized to mitochondrial matrix, we created stable clones overexpressing Bcl-2 gene. Bcl-2 has been studied extensively and its role in apoptosis regulation at the level of mitochondria is well established. Specifically, it localizes to the outer mitochondrial membrane where it inhibits a multitude of pro-apoptotic signaling events $(53,54)$. Mutants stably overexpressing $\mathrm{Bcl}-2$, in both cell types, showed significant reduction in $\mathrm{Cr}(\mathrm{VI})$ induced apoptosis (Figs. 8A-B). Notably, the relative intensities of apoptosis reduction were comparable to observations in GPx and MnSOD overexpressing clones, suggesting additional signaling cascades between mROS production and outer mitochondrial membrane signaling events.

\subsection{Discussion}

In order to survive, cells must respond to changes in environment. The adaptability of our cellular systems is considerable, but not unlimited. Nowhere is that more evident than in neoplasia. The Warburg effect, or increased dependency on glycolysis in cancer cells, has been a long-standing observation (7-9). Despite numerous experimental findings of this metabolic alteration in a wide spectrum of human cancers, the mechanisms underlying it and potential therapeutic implications still remain a subject of considerable controversy (8-10). The central question is whether a shift to glycolysis is simply an adaptation due to low availability of oxygen in tumor microenvironment (Figure 9, a majority opinion), or, a consequence of "respiratory system injury", as Warburg himself 
thought, forcing the cells to use the glycolytic pathway to generate ATP. While multiple lines of evidence in the literature support both contentions, several fundamental challenges face "the majority opinion". First, cancer cells maintain the glycolytic phenotype in cell culture where oxygen is freely available. Second, the contention that once adaptation to glycolysis occurs, it becomes irreversible, is not supported by evidence. Contrary, several reports highlight significant plasticity of mitochondria under changing metabolic conditions (11-13). If mitochondria are so energy substrate versatile, and produce 36 ATP molecules per glucose unit vs. 2 ATPs from glycolysis, what benefit would outweigh the tremendous net energy cost? Collectively, our data point toward ROS (Figure 10).

$\mathrm{Cr}(\mathrm{VI})$ is a known human carcinogen that has been associated with lung cancer (25). Its cytotoxic and mutagenic effects have been studied extensively and point toward ROS as causal in $\mathrm{Cr}(\mathrm{VI})$-induced toxicity and mutagenesis. Indeed, our data show a dose dependent increase in apoptosis in non-tumorigenic BEAS-2B cells as well as tumorigenic $\mathrm{H} 460$ cells. $\mathrm{H} 460$ cells, however, are approximately 4 fold more resistant to $\mathrm{Cr}(\mathrm{VI})$-induced apoptosis than their non-tumorigenic counterparts (Figs. 1A-B). When exposed to a functioning oxidative phosphorylation-dependent, energy substrate-only, environment, the observed apoptosis resistance is abrogated (Figs. 2A-C). This is the first report of energy substrate modulation of $\mathrm{Cr}(\mathrm{VI})$-induced toxicity indicating a link between oxidative phosphorylation only metabolism and mechanism of $\mathrm{Cr}(\mathrm{VI})$-induced toxicity. Furthermore, observations in Fig. 2 suggest critical 'differences' between $\mathrm{H} 460$ and BEAS-2B cells in support of Warburg's "respiratory defect". Given the observations in Figure 2, we focused on delineating deeper mechanistic aspects of $\mathrm{Cr}(\mathrm{VI})$-induced apoptosis in our system.

$\mathrm{Cr}(\mathrm{VI})$ is actively transported into cells by anionic transport system at the cellular level (55) and is metabolically converted to the ultimate reduced form, $\mathrm{Cr}(\mathrm{III})$, in a process that also produced ROS. Since generation of ROS is a consequence of 
$\mathrm{Cr}(\mathrm{VI})$ exposure, we also demonstrated the role of ROS in $\mathrm{Cr}(\mathrm{VI})$-induced apoptosis of non-tumorigenic BEAS-2B and tumorigenic H460 cells. Consistent with the observation that reduction of $\mathrm{Cr}(\mathrm{VI})$ inside the cell produces $\mathrm{ROS}$, our results showed that $\mathrm{Cr}(\mathrm{VI})$ was able to induce $\cdot \mathrm{OH}$ radical generation in both cell types (Figs. 3A-B). The relative intensity of the ESR spectra was significantly lower in the tumorigenic H460 cells (Fig. 3C) at both concentrations studied. Decrease in mitochondrial membrane potential has been linked to mitochondrial ROS production in response to toxic stimuli $(11,13)$ as well as overall mitochondrial function (15). This was the case in our system as well where we observed a dose dependent decrease in mitochondrial membrane potential in both cell types (Fig. 3D). The relative decrease was significantly higher in nontumorigenic BEAS-2B cells.

In order to establish the link between $\mathrm{Cr}(\mathrm{VI})$-induced ROS production and functioning mitochondrial metabolism, we evaluated the relative ESR peak intensity as a function of energy substrate available to the cells. Figures $4 \mathrm{~A}-\mathrm{C}$ show that conditions forcing oxidative phosphorylation resulted in a significant increase in ROS production in tumorigenic $\mathrm{H} 460$ cells, whereas BEAS-2B cells showed no significant difference. Consistent with the observed energy substrate effects on ROS production, we observed a significant increase in the mitochondrial membrane potential in both cell types (Fig. 4D) when oxidative phosphorylation was forced. Since we observed the correlation between energy substrate, apoptosis and ROS production, we set out to establish the potential causal relationship between the observed $\mathrm{Cr}(\mathrm{VI})$-induced ROS and apoptosis. Increase in ROS production was achieved via pretreatment of the cells with an established ROS inducer BSO, while NAC was used as a ROS inhibitor. BSO pretreatment led to a significant increase in $\mathrm{Cr}(\mathrm{VI})$-induced apoptosis in both cell types, while NAC virtually abrogated the effect (Figs. 5A-C), suggesting a causal relationship between the ROS and apoptosis in our system. This observation was consistent with previous reports on the role of ROS in $\mathrm{Cr}(\mathrm{VI})$-induced apoptosis (29-31). 
While ROS production is a known factor in $\mathrm{Cr}(\mathrm{VI})$-induced toxicity, their subcellular origins are not well understood. To determine the source of ROS involved in $\mathrm{Cr}(\mathrm{VI})$-induced apoptosis in our system, we utilized DPI and rotenone. Rotenone has previously been shown to inhibit mitochondrial ROS while DPI is known to inhibit cellular NADPH oxidase; both are considered as indicators of the mitochondrial and cytosolic ROS, respectively (56-58). Cr(VI)-induced ROS generation and apoptosis was significantly inhibited by DPI and rotenone, with the effect of the latter being more dominant (Fig. 6A-B) in both cell types. This indicates that total ROS produced are important in $\mathrm{Cr}(\mathrm{VI})$-induced apoptosis, but mitochondrial ROS play a major role in our system. DPI and rotenone are widely used in mechanistic studies; however, secondary effects cannot be excluded due to their small-molecule nature. In order to confirm the causal relationship mitochondrial ROS plays in $\mathrm{Cr}(\mathrm{VI})$-induced apoptosis in our system, stable cell lines overexpressing GPx and MnSOD were created for both cell types. Gene transfection studies using GPX- and SOD-overexpressing cells confirmed that mitochondrial ROS play a crucial role in $\mathrm{Cr}(\mathrm{VI})$-induced apoptosis (Figs. 7A-C). Apoptosis was virtually abrogated in both, the tumorigenic $\mathrm{H} 460$ as well as nontumorigenic BEAS-2B mutants.

To determine whether mROS production in our system represents a point of no return for the cell in $\mathrm{Cr}(\mathrm{VI})$-induced apoptosis, stable clones overexpressing $\mathrm{Bcl}-2$ gene were created. $\mathrm{Bcl}-2$ has been studied extensively and its role in apoptosis regulation at the level of mitochondria is well established. Specifically, it localizes to the outer mitochondrial membrane where it inhibits a multitude of pro-apoptotic signaling events $(53,54)$. Mutants stably overexpressing Bcl-2, in both cell types, showed significant reduction in $\mathrm{Cr}(\mathrm{VI})$-induced apoptosis (Figs. 8A-B) comparable in intensity to the observations in GPx and MnSOD-overexpressing clones. Together, these observations suggest additional signaling cascades between mROS production in the matrix and outer mitochondrial membrane signaling events. 
In summary, our data provide evidence that apoptosis induced by $\mathrm{Cr}(\mathrm{VI})$ is mediated through the mitochondria-dependent signaling pathway. ROS play a causal role in $\mathrm{Cr}(\mathrm{VI})$-induced apoptosis of non-tumorigenic human bronchial epithelial BEAS-2B cells and human lung cancer $\mathrm{H} 460$ cells. The mechanism by which $\mathrm{Cr}(\mathrm{VI})$ induces apoptosis involves rapid generation of ROS in the mitochondrial matrix and consequent depolarization of the outer mitochondrial membrane. Further, mitochondrial ROS generation resulting from $\mathrm{Cr}(\mathrm{VI})$ insult is quantitatively dependent on the degree of cellular commitment to oxidative phosphorylation driven energy production. Forcing of oxidative phosphorylationonly metabolism leads to an abrogation of native apoptosis resistance in human lung cancer $\mathrm{H} 460$ cells vs. their non-tumorigenic BEAS-2B counterparts.

Collectively, our data present a mechanistic advancement in the understanding of molecular effectors underlying the Warburg's "respiratory defect" hypothesis and put mitochondrial ROS as causal agents of programmed cell death in $\mathrm{Cr}(\mathrm{VI})$ induced toxicity and carcinogenesis (Fig. 11). 
Figure 1

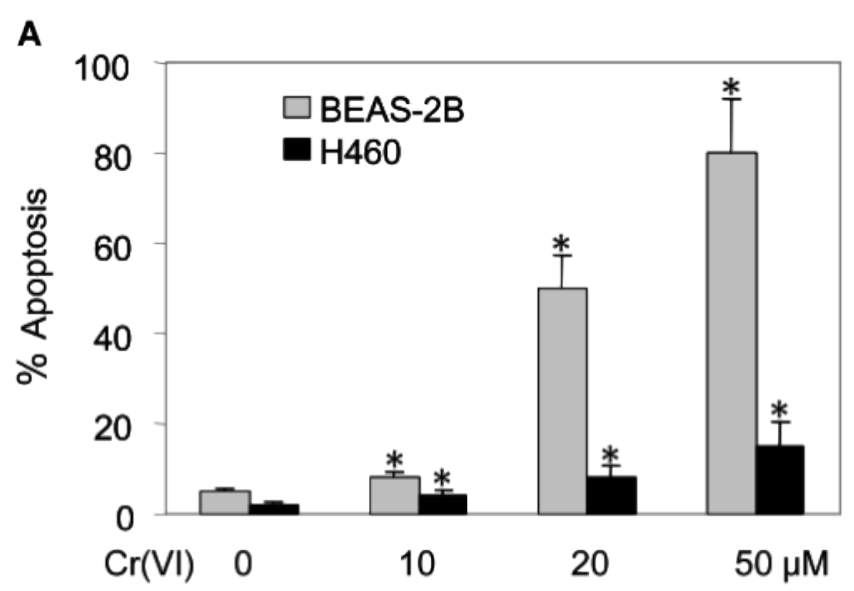

B
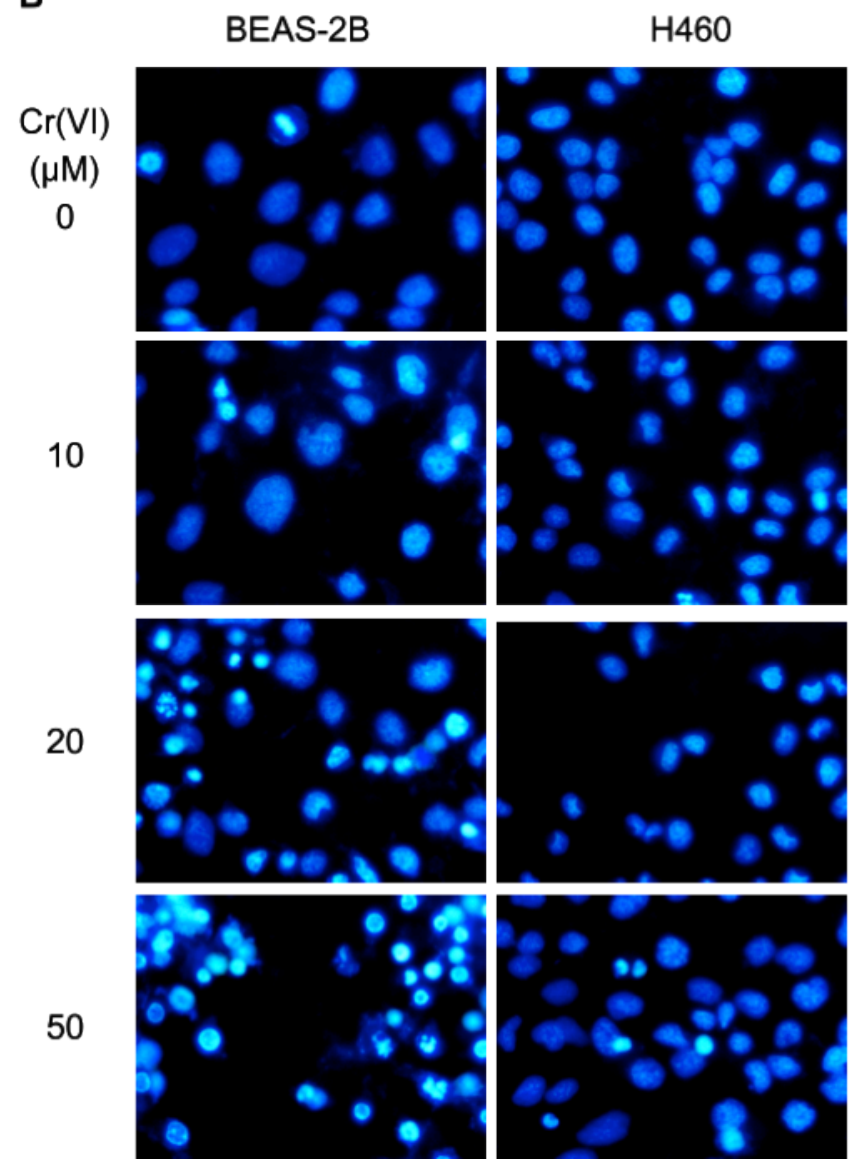

FIGURE 1. Induction of apoptosis by $\mathrm{Cr}(\mathrm{VI})$ in human lung epithelial BEAS-2B and human lung cancer $\mathrm{H} 460$ cells. $A$, subconfluent monolayers of BEAS-2B and $\mathrm{H} 460$ cells were exposed to varying doses of $\mathrm{Cr}(\mathrm{VI})(0-50 \mu \mathrm{M})$ for $12 \mathrm{~h}$, and the cells were analyzed for apoptosis by Hoechst 33342 assay. $B$, fluorescence micrographs of treated cells stained with Hoechst dye. Apoptotic cells exhibited shrunken and fragmented nuclei with bright nuclear fluorescence. Values are mean \pm S.D. $(\mathrm{n}>3) .{ }^{*}, p<0.05$ versus non-treated control. 
Figure 2

A
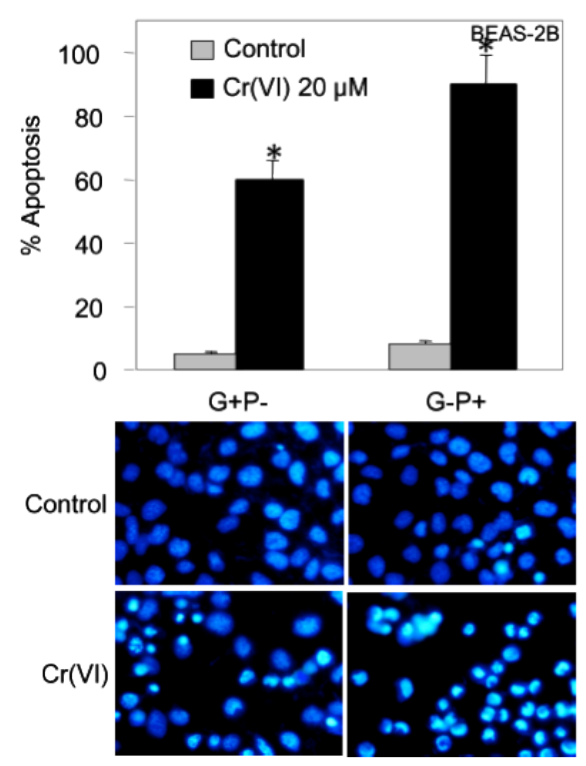

B
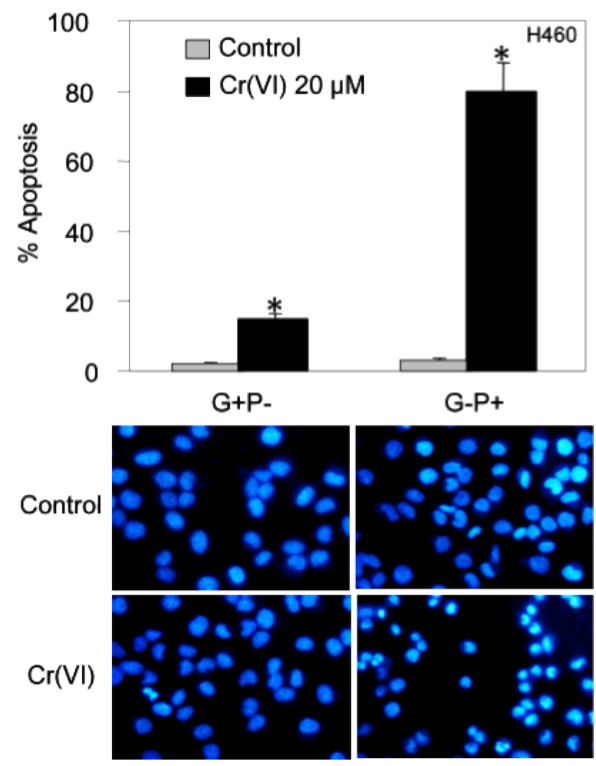

C

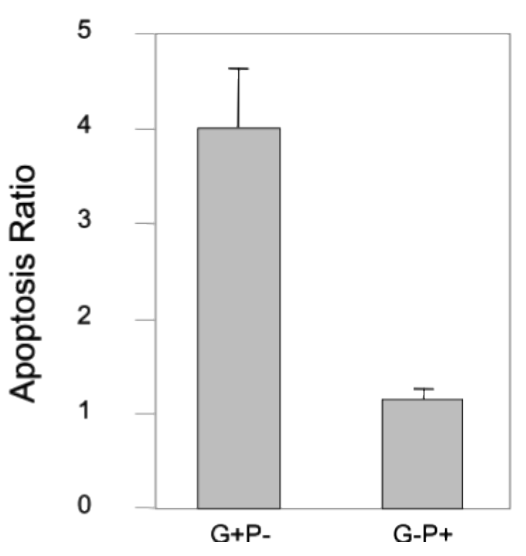

FIGURE 2. Effect of energy substrate on $\mathrm{Cr}(\mathrm{VI})$-induced apoptosis in human lung epithelial BEAS-2B and human lung cancer $\mathrm{H} 460$ cells. $A$, subconfluent monolayers of BEAS-2B were exposed to $20 \mu \mathrm{M}$ dose of $\mathrm{Cr}(\mathrm{VI})$ for $12 \mathrm{~h}$ in either $\mathrm{G}+\mathrm{P}$ - or $\mathrm{G}-\mathrm{P}+$ medium, and the cells were analyzed for apoptosis by Hoechst 33342 assay. $B$, subconfluent monolayers of $\mathrm{H} 460$ cells were exposed to $20 \mu \mathrm{M}$ dose of $\mathrm{Cr}(\mathrm{VI})$ for $12 \mathrm{~h}$ in either $\mathrm{G}+\mathrm{P}$ - or $\mathrm{G}-\mathrm{P}+$ medium, and the cells were analyzed for apoptosis by Hoechst 33342 assay. $C$, Relative apoptosis resistance in $\mathrm{H} 460$ vs. BEAS-2B cells as a function of available energy substrate. Values are mean \pm S.D. $(n>3) .{ }^{*}, p<$ 0.05 versus non-treated control. 
Figure 3

A

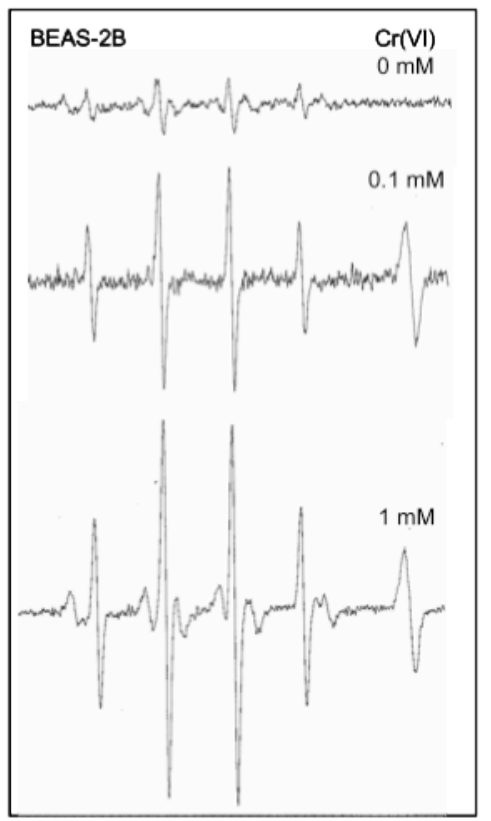

B

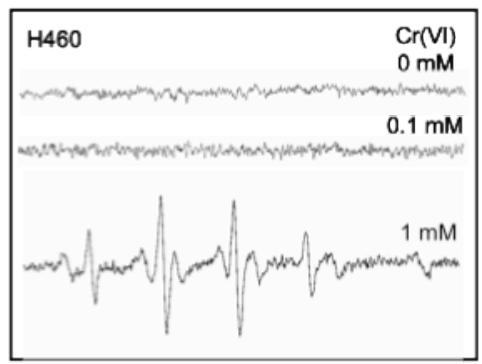

C

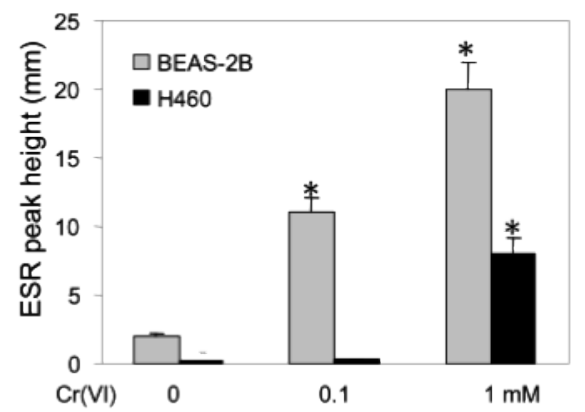

D

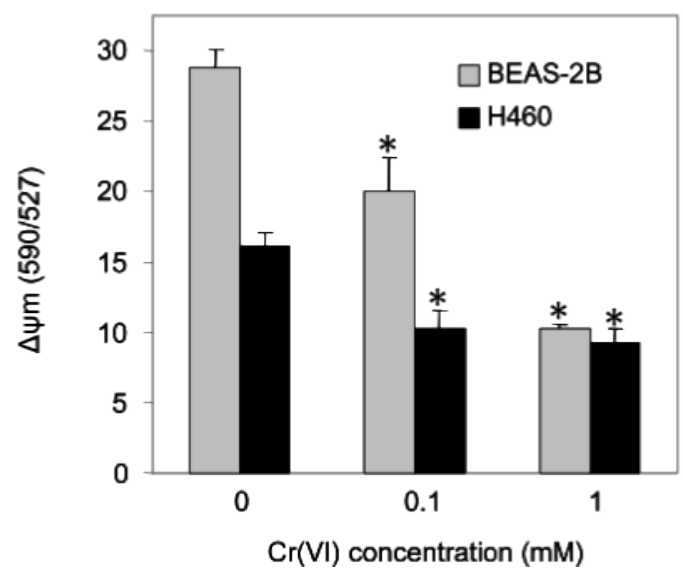

FIGURE 3. $\mathrm{Cr}(\mathrm{VI})$-induced ROS production and mitochondrial membrane depolarization. $A$, BEAS-2B cells were exposed to varying concentrations of $\mathrm{Cr}(\mathrm{VI})(0.1$ and $1 \mathrm{mM})$ and the cells were analyzed for ROS production using electron spin resonance (ESR) spectroscopy. $B, \mathrm{H} 460$ cells were exposed to varying doses of $\mathrm{Cr}(\mathrm{VI})(0.1$ and $1 \mathrm{mM})$ and the cells were analyzed for ROS production using ESR. C, Relative difference in the ROS intensity in BEAS-2B and H460 cells. $D$, Mitochondrial membrane depolarization as indicated by JC-1 fluorescence. Values are mean \pm S.D. $(n>3) .{ }^{*}, p<0.05$ versus non-treated control. 
Figure 4
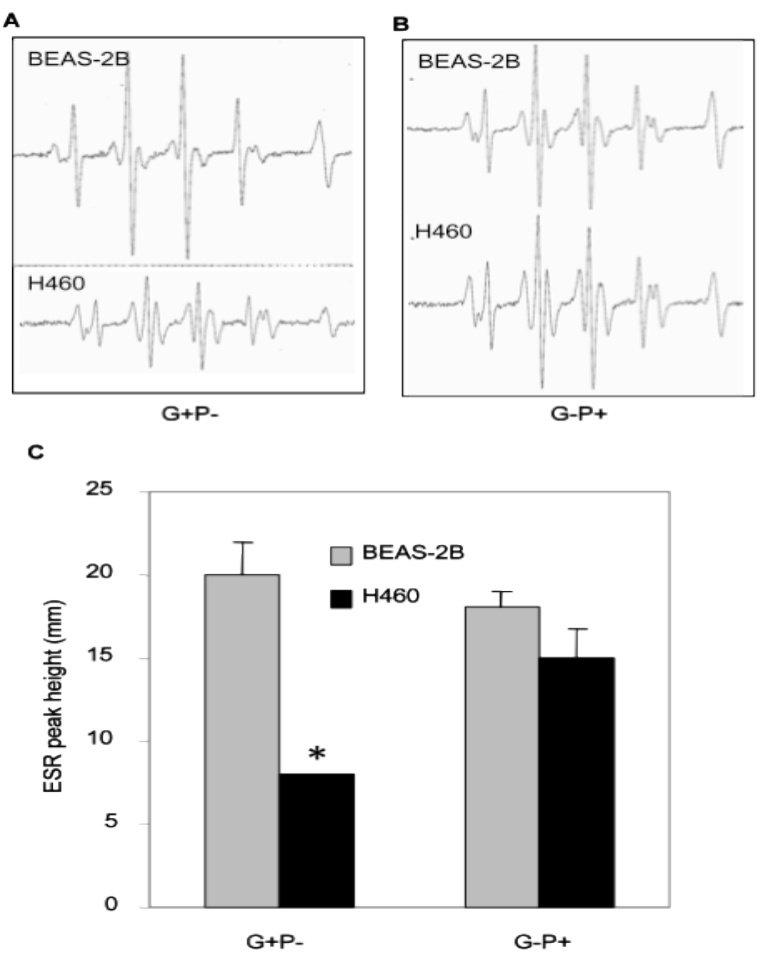

D

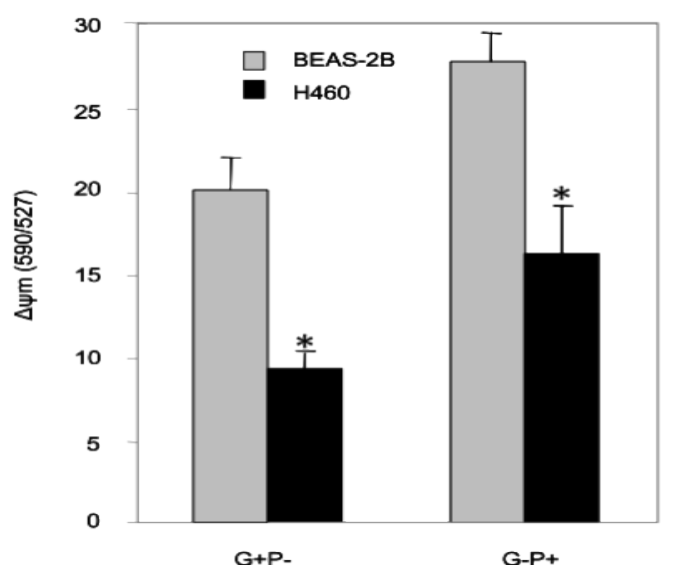

FIGURE 4. Effect of energy substrate on ROS production and mitochondrial membrane depolarization. $A$, BEAS-2B cells were exposed to $1 \mathrm{mM} \mathrm{Cr}(\mathrm{VI})$ and the cells were analyzed for ROS production using electron spin resonance spectroscopy (ESR) in G+P- and G-P+ media. $B$, $\mathrm{H} 460$ cells were exposed to $1 \mathrm{mM} \mathrm{Cr}(\mathrm{VI})$ and the cells were analyzed for ROS production using electron spin resonance spectroscopy (ESR) in G+P- and G-P+ media. $C$, Relative difference in the ROS intensity in BEAS-2B and $\mathrm{H} 460$ cells as a function of energy substrate. $D$, Relative difference in mitochondrial membrane depolarization as a function of energy substrate. Values are mean \pm S.D. $(\mathrm{n}>3) .{ }^{*}, p<0.05$ versus BEAS-2B cells. 
Figure 5

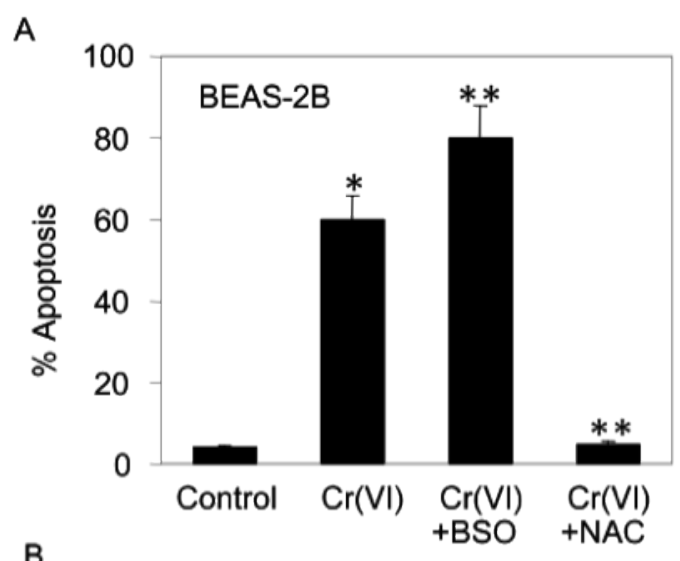

C

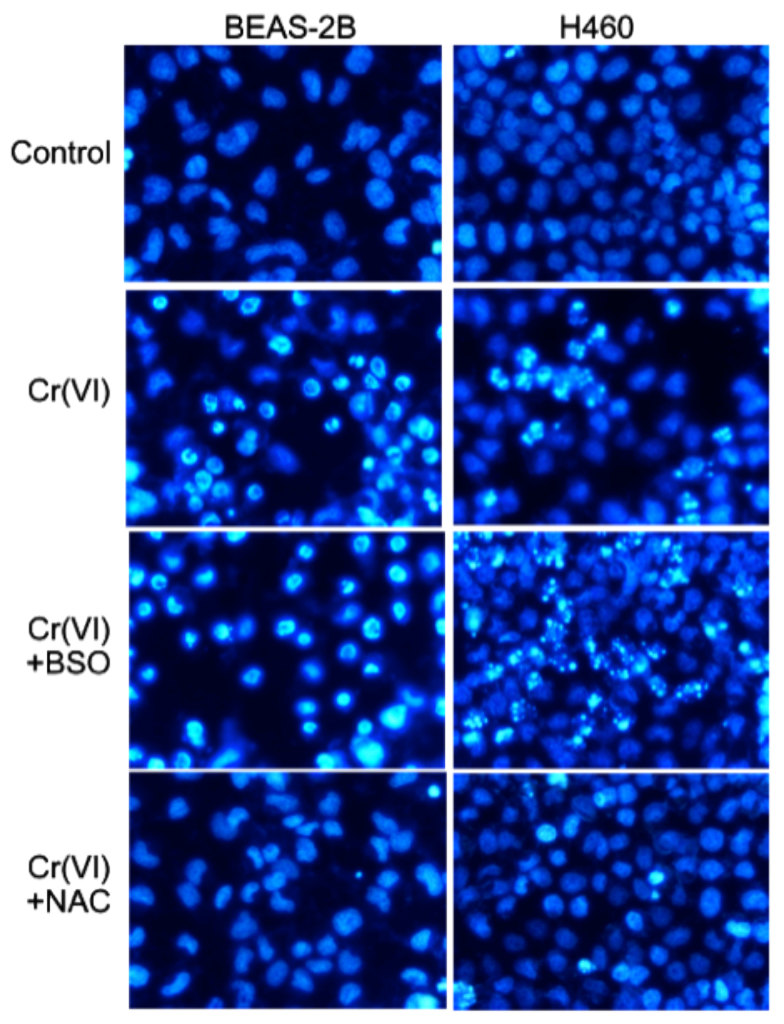

FIGURE 5. Effect of ROS modulators on $\mathrm{Cr}(\mathrm{VI})$-induced apoptosis in BEAS-2B and $\mathbf{H} 460$ cells. $A$, subconfluent monolayers of BEAS-2B cells were pretreated for $1 \mathrm{~h}$ with BSO or NAC and exposed to $20 \mu \mathrm{M} \mathrm{Cr}(\mathrm{VI})$ for $12 \mathrm{~h}$, and the cells were analyzed for apoptosis by Hoechst 33342 assay. $B$, subconfluent monolayers of $\mathrm{H} 460$ cells were pretreated for $1 \mathrm{~h}$ with BSO or NAC and exposed to $20 \mu \mathrm{M} \mathrm{Cr}(\mathrm{VI})$ for $12 \mathrm{~h}$, and the cells were analyzed for apoptosis by Hoechst 33342 assay. $C$, fluorescence micrographs of treated cells stained with Hoechst dye. Apoptotic cells exhibited shrunken and fragmented nuclei with bright nuclear fluorescence. Values are mean \pm S.D. $(\mathrm{n}>3) .{ }^{*}, p<0.05$ versus non-treated control. ${ }^{* *}$ versus $\mathrm{Cr}(\mathrm{VI})$-treated control. 
Figure 6
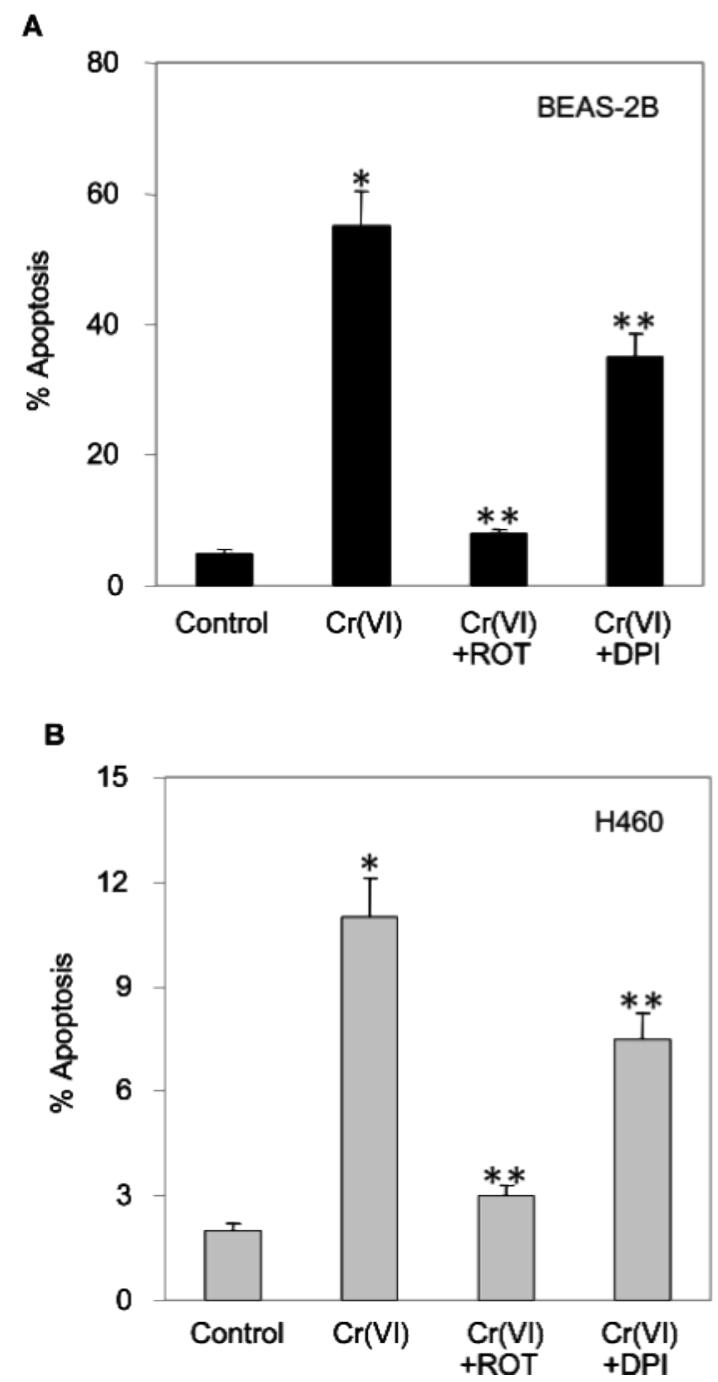

FIGURE 6. Source of ROS involved in $\mathrm{Cr}(\mathrm{VI})$-Induced Apoptosis $A$, subconfluent monolayers of BEAS-2B cells were pretreated for $1 \mathrm{~h}$ with ROT or DPI and exposed to $20 \mu \mathrm{M}$ $\mathrm{Cr}(\mathrm{VI})$ for $12 \mathrm{~h}$, and the cells were analyzed for apoptosis by Hoechst 33342 assay. $B$, subconfluent monolayers of $\mathrm{H} 460$ cells were pretreated for $1 \mathrm{~h}$ with ROT or DPI and exposed to $20 \mu \mathrm{M} \mathrm{Cr}(\mathrm{VI})$ for $12 \mathrm{~h}$, and the cells were analyzed for apoptosis by Hoechst 33342 assay. Values are mean \pm S.D. $(\mathrm{n}>3) .{ }^{*}, p<0.05$ versus non-treated control. ${ }^{* *}$ versus $\mathrm{Cr}(\mathrm{VI})$-treated control. 
Figure 7

A

$$
\begin{aligned}
& \text { MOP* GPt } \\
& \text { Transfection }
\end{aligned}
$$

B

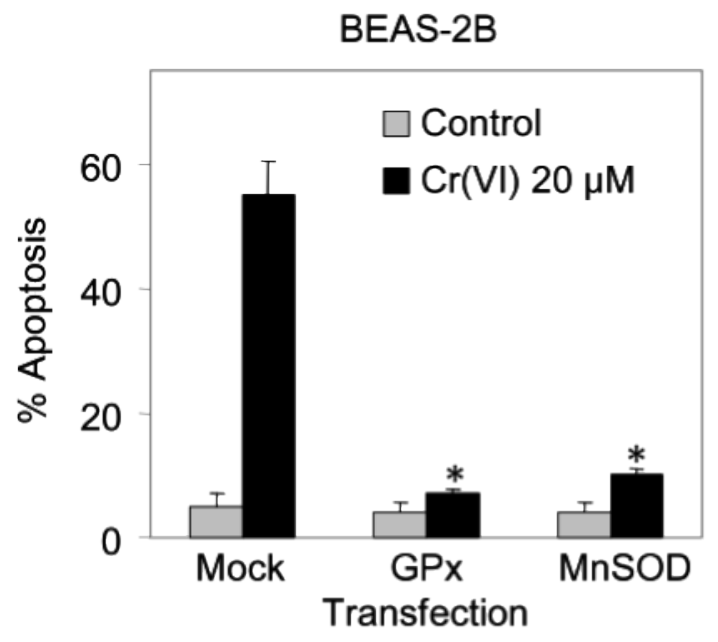

C

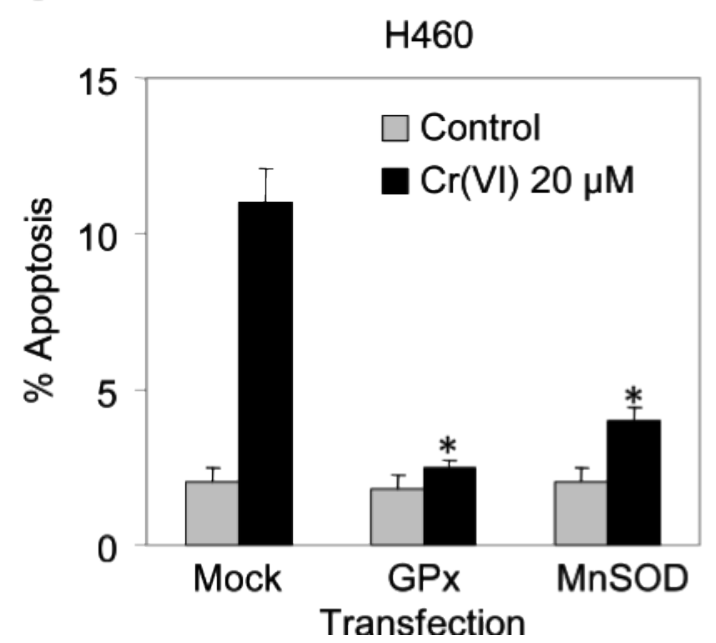

FIGURE 7. GPx and MnSOD overexpression increases cell death resistance to $\mathrm{Cr}(\mathrm{VI})$. $A$, Western blot analysis. BEAS-2B and H460 cells were transfected with GPx, MnSOD, or control pcDNA3 plasmid. $\beta$-actin was used as a loading control. $B$ and $C$, Transfected cells were treated with $20 \mu \mathrm{M} \mathrm{Cr}(\mathrm{VI})$ for $12 \mathrm{~h}$ and the effect of GPx and MnSOD overexpression on apoptosis was determined by Hoechst 33342 assay. Plots are mean \pm S.D. $(n=3)$. ${ }^{*}, p<0.05$ versus mocktransfected $\mathrm{Cr}(\mathrm{VI})$-treated controls. 
Figure 8

A

BEAS-2B

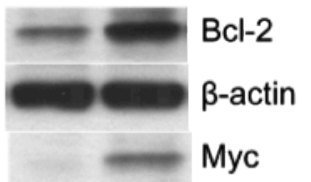

Lane 1: Mock transfected cells

Lane 2: Bcl-2-myc transfected cells

B

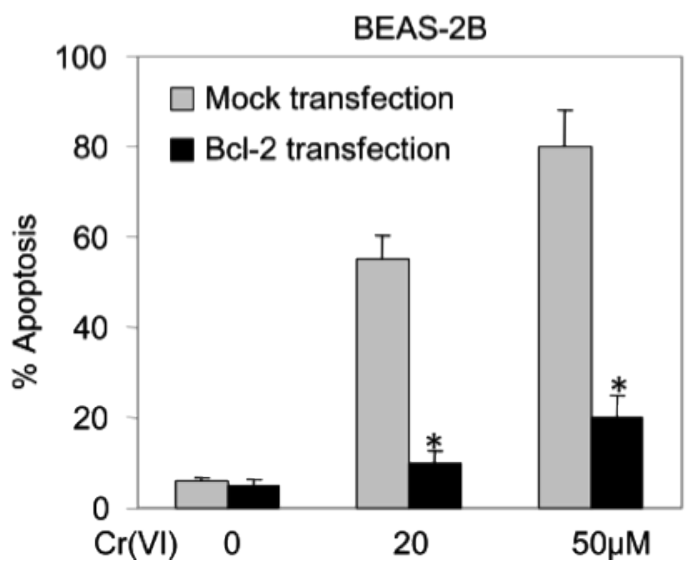

$\mathrm{H} 460$

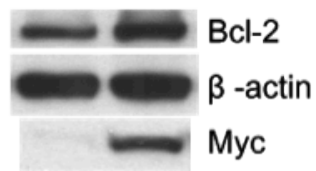

Lane 1: Mock transfected cells

Lane 2: Bcl-2-myc transfected cells

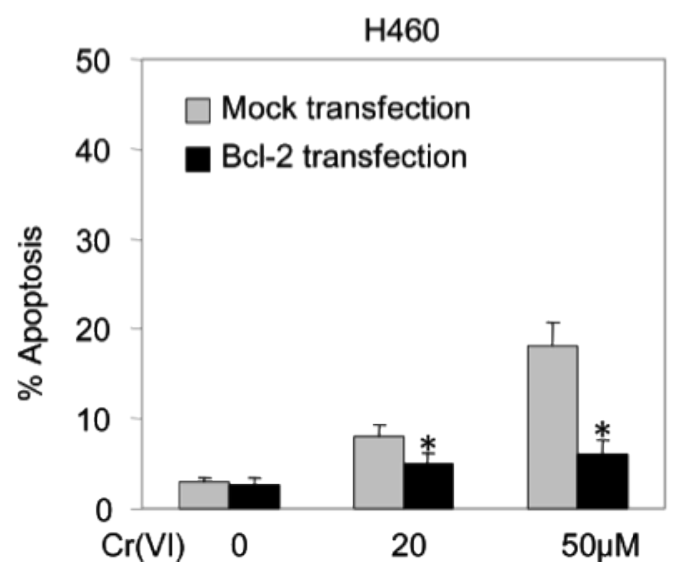

FIGURE 8. Bcl-2 overexpression decreases $\mathrm{Cr}(\mathrm{VI})$-induced apoptosis. $A$, Western blot analysis. BEAS-2B and $\mathrm{H} 460$ cells were stably transfected with myc-tagged $\mathrm{Bcl}-2$ plasmid or control pcDNA3 plasmid. $\beta$-actin was used as a loading control. $B$, Transfected cells were treated with 20 and $50 \mu \mathrm{M} \mathrm{Cr}(\mathrm{VI})$ for $12 \mathrm{~h}$ and apoptosis was determined by Hoechst 33342 assay. Plots are mean \pm S.D. $(n=3) .{ }^{*}, p<0.05$ versus mock-transfected controls. 

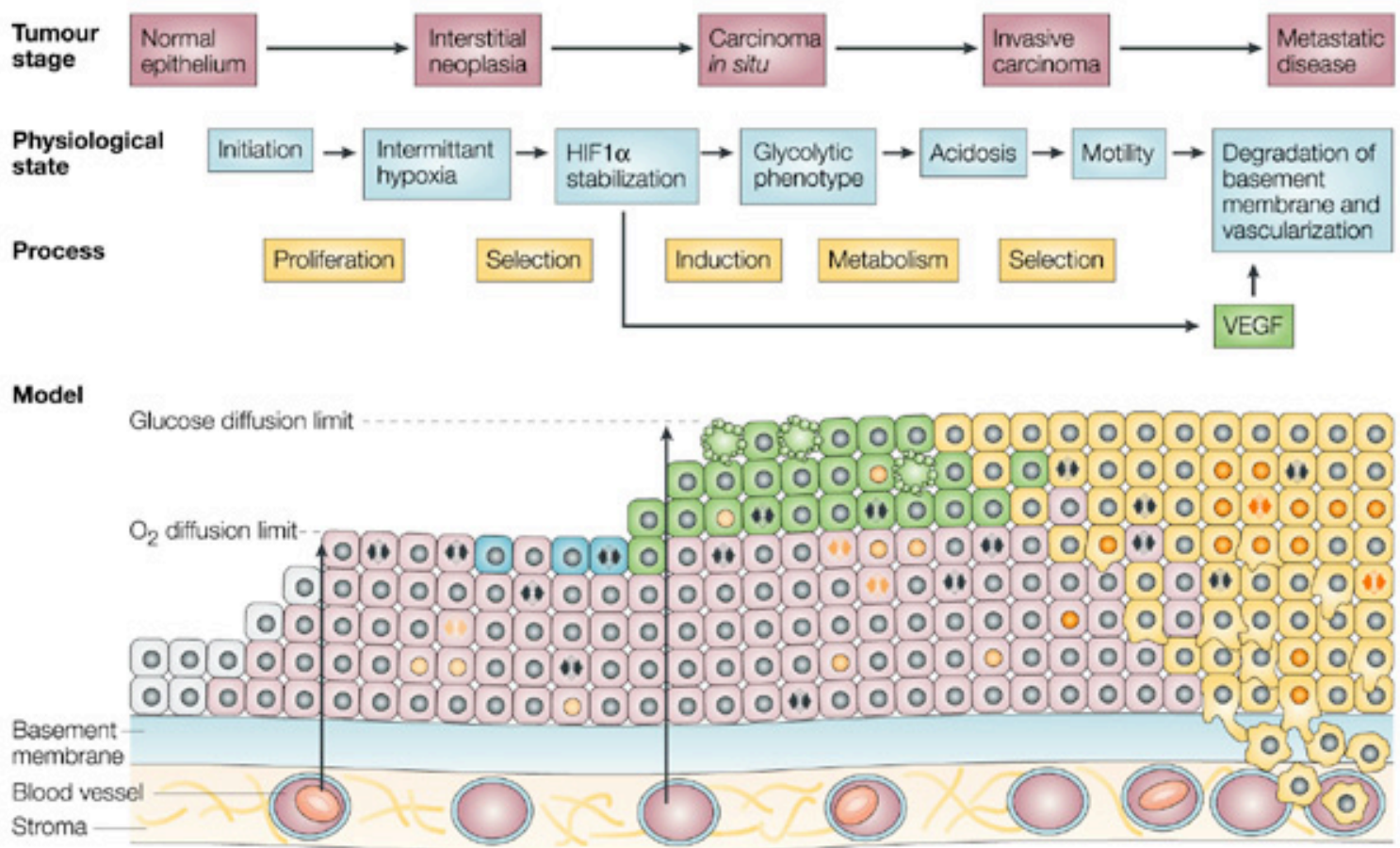

Figure 9. Prevailing model of carcinogenesis. Normal epithelial cells (grey) become hyperproliferative (pink) following induction. As they reach the oxygen diffusion limit, they become hypoxic (blue), which can either lead to cell death (apoptotic cells shown with blebbing) or adaptation of a glycolytic phenotype (green), which allows cells to survive. As a consequence of glycolysis, lesions become acidotic, which selects for motile cells (yellow) that eventually breach the basement membrane. 
(4) thioredoxin detoxification (5) Glutathione detoxification

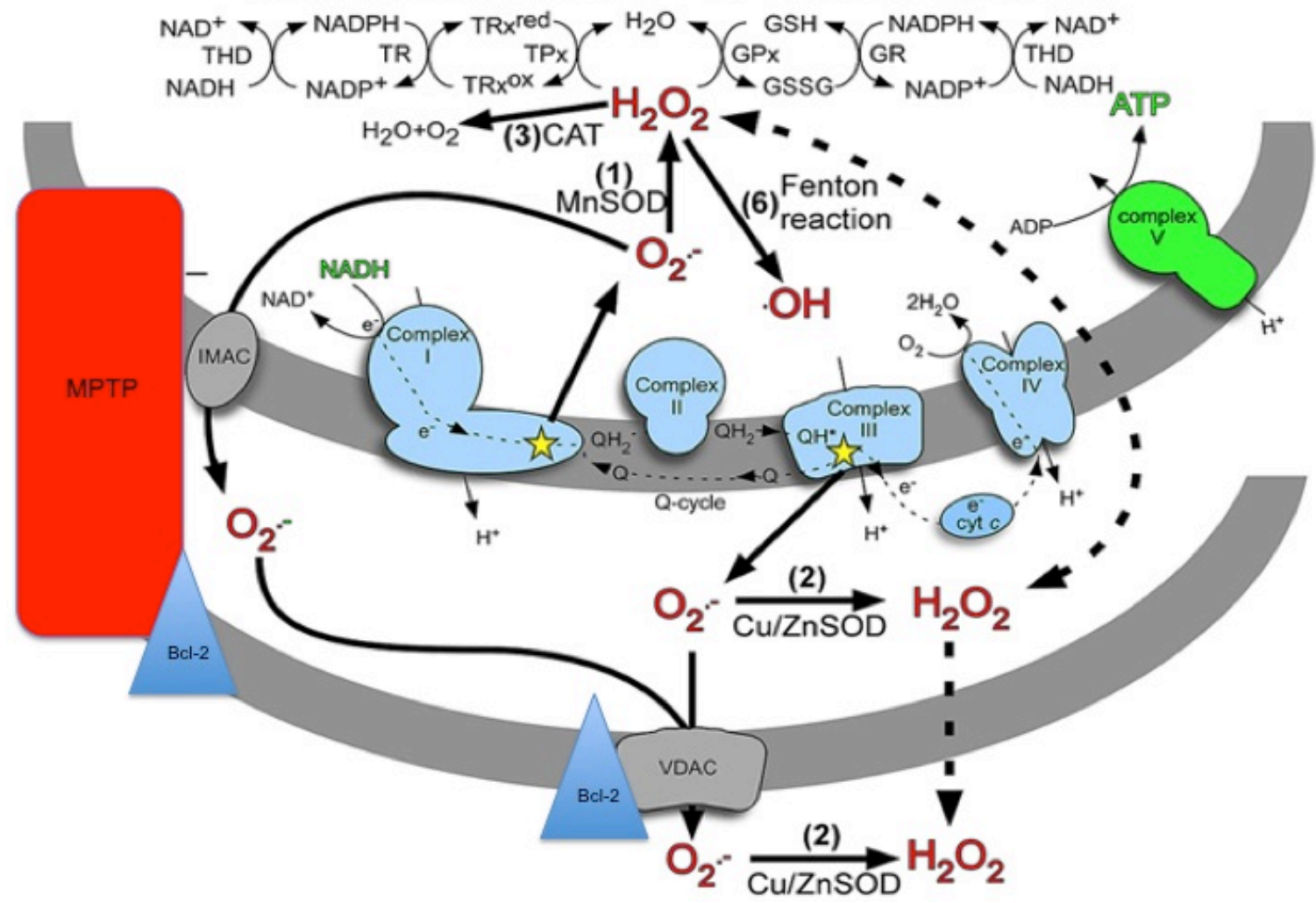

Figure 10. Mitochondrial ROS production and defense. Superoxide $\left(\mathrm{O}_{2}{ }^{-}\right)$generated by the respiratory chain is mostly released to the matrix at complex I and the inter membrane space (IMS) at complex III. $\mathrm{O}_{2}-{ }^{--}$can naturally dismute to hydrogen peroxide $\left(\mathrm{H}_{2} \mathrm{O}_{2}\right)$ or is enzymatically dismuted by matrix MnSOD (1) or Cu/ZnSOD (2) in the IMS or cytosol. $\mathrm{H}_{2} \mathrm{O}_{2}$ is detoxified in the matrix by catalase (3), the thioredoxin/thioredoxin peroxidase system (4), or the glutathione/glutathione peroxidase system (5). Alternately, $\mathrm{H}_{2} \mathrm{O}_{2}$ can react with metal ions to generate the highly reactive hydroxyl radical $\left({ }^{\circ} \mathrm{OH}\right)$ via Fenton chemistry (6). $\mathrm{O}_{2}{ }^{-}$is not membrane permeable but can pass through ion channels (solid lines), whereas $\mathrm{H}_{2} \mathrm{O}_{2}$ can pass freely through membranes (dashed lines). Bcl-2 modulates MPTP opening as well as VDAC activity. $\mathrm{O}_{2}{ }^{-}$, superoxide; $\mathrm{H}_{2} \mathrm{O}_{2}$, hydrogen peroxide; MnSOD, manganese superoxide dismutase; Cu/ZnSOD, copper/zinc superoxide dismutase; CAT, catalase; THD, NADH transhydrogenase; TR, thioredoxin reductase; TPx, thioredoxin peroxidase; TRx ${ }^{\text {red }}$, reduced thioredoxin; TRx ${ }^{\text {ox }}$, oxidized thioredoxin; GSH, glutathione; GSSG, glutathione disulfide; IMAC, inner membrane ion channel; VDAC, voltage dependant anion channel; MPTP, mitochondrial permeability transition pore; Bcl2, B-cell lymphoma 2 antiapoptotic effector. 


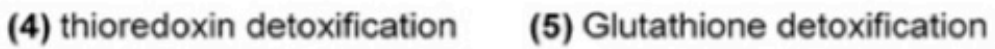

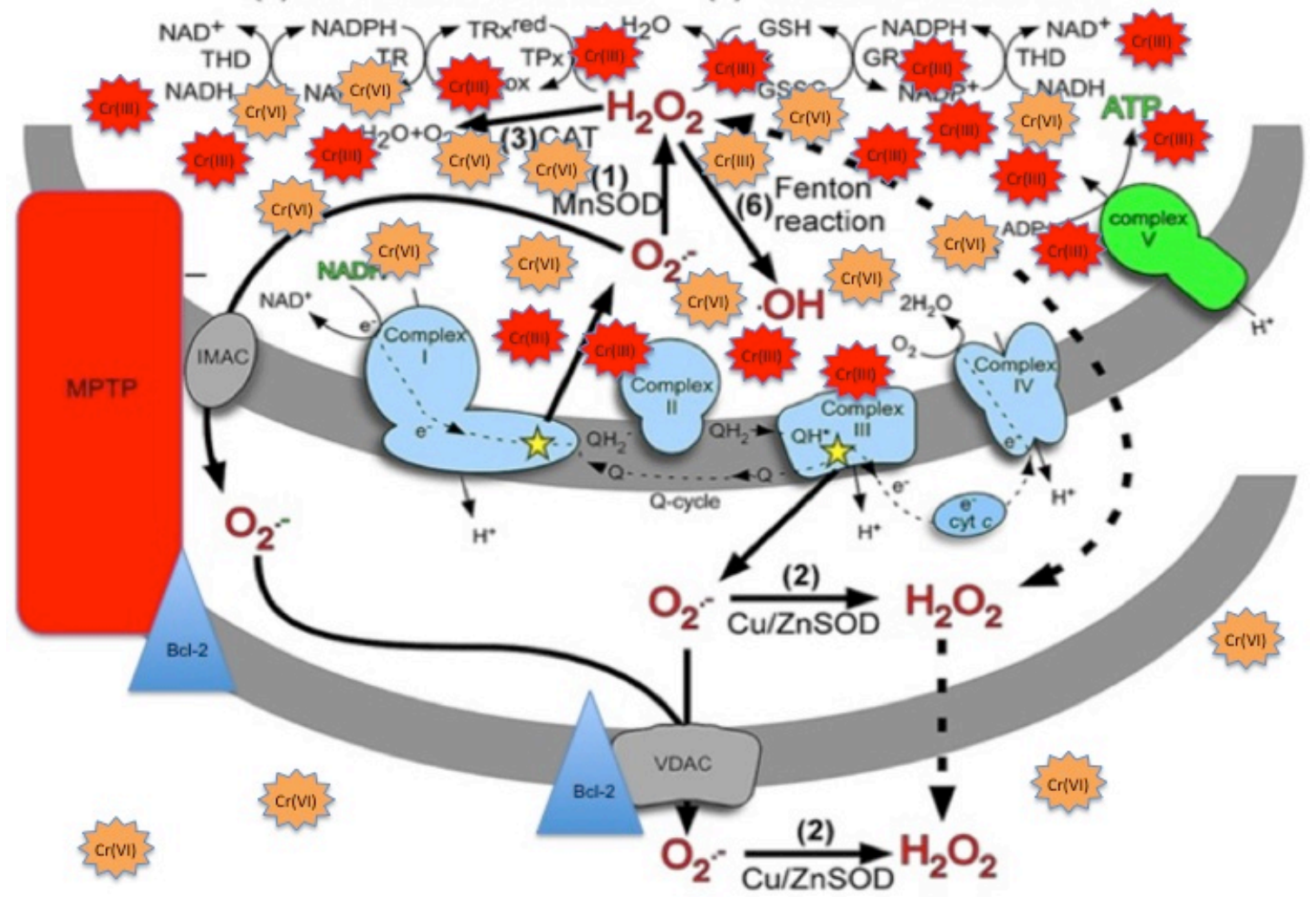

Figure 11. Proposed mechanism contributing to $\mathrm{Cr}(\mathrm{VI})$-induced toxicity and carcinogenesis $\mathrm{Cr}(\mathrm{VI})$ accumulates in the mitochondrial matrix at higher relative concentrations than in the cytosol/nucleus and it significantly amplifies the ROS burden via Fenton chemistry "explosion" leading to acute and chronic (mDNA damage) "respiratory defect". Consequently, mitochondrial signaling integrity is lost and the cell (1) amplifies glycolysis as the only remaining viable energy source and (2) loses commitment phase apoptotic signaling hub. 


\subsection{References}

1. Green, D. R., and Reed, J. C. Mitochondria and apoptosis. Science (Wash. DC), 281:1309-1312, 1998.

2. Ferri, K. F., and Kroemer, G. Organelle-specific initiation of cell death pathways. Nat.Cell. Biol., 3: E255-E263, 2001.

3. Wang, X. The expanding role of mitochondria in apoptosis. Genes Dev., 15: 2922-2933, 2001.

4. Jacobson, M. D., Weil, M., and Raff, M. C. Programmed cell death in animal development. Cell, 88: 347-354, 1997.

5. Thompson, C. B. Apoptosis in the pathogenesis and treatment of disease. Science (Wash. DC), 267: 1456-1462, 1995.

6. Reed, J. C. Mechanisms of apoptosis avoidance in cancer. Curr. Opin. Oncol., 11:68-75, 1999.

7. Warburg, O. The Metabolism of Tumors. pp. 254-270. London: Arnold Constable,1930.

8. Dang, C. V., and Semenza, G. L. Oncogenic alterations of metabolism. Trends Biochem. Sci., 24: 68-72, 1999.

9. Semenza, G. L., Artemov, D., Bedi, A., Bhujwalla, Z., Chiles, K., Feldser, D., Laughner, E., Ravi, R., Simons, J., Taghavi, P., and Zhong, H. The metabolism of tumours: 70 years later. Novartis Found. Symp., 240: 251-260, 2001.

10. Ziegler, A., von Kienlin, M., Decorps, M., and Remy, C. High glycolytic activity in rat glioma demonstrated in vivo by correlation peak $1 \mathrm{H}$ magnetic resonance imaging. Cancer Res., 61: 5595-5600, 2001.

11. Pedersen, P. L. Tumor mitochondria and the bioenergetics of cancer cells. Prog. Exp. Tumor Res., 22: 190-274, 1978.

12. Cuezva, J. M. K. M., de Heredia, M. L., Krajewski, S., Santamaria, G., Kim, H., Zapata, J. M., Marusawa, H., Chamorro, M., and Reed, J. C. The bioenergetic signature of cancer: a marker of tumor progression. Cancer Res., 62: 6674-6681, 2002. 
13. Springer, E. Comparative study of the cytoplasmic organelles of epithelial cell lines derived from human carcinomas and nonmalignant tissues. Cancer Res., 40: 803-817, 1980.

14. Hoberman, $\mathrm{H}$. Is there a role for mitochondrial genes in carcinogenesis? Cancer Res., 35: 3332-3335, 1975.

15. Simonnet, H., Alazard, N., Pfeiffer, K., Gallou, C., Beroud, C., Demont, J., Bouvier, R., Schagger, H., and Godinot, C. Low mitochondrial respiratory chain content correlates with tumor aggressiveness in renal cell carcinoma. Carcinogenesis (Lond.), 23: 759-768, 2002.

16. Irwin, C., Malkin, L., and Morris, H. Differences in total mitochondrial proteins and proteins synthesized by mitochondria from rat liver and Morris hepatomas 9618A, 5123C, and 5123tc. Cancer Res., 38: 1584-1588, 1978.

17. Senior, A., McGowan, S., and Hilf, R. A comparative study of inner membrane enzymes and transport systems in mitochondria from R3230AC mammary tumor and normal rat mammary gland. Cancer Res., 35: 20612067, 1975.

18. Stocco, D., and Hutson, J. Characteristics of mitochondria isolated by rate zonal centrifugation from normal liver and Novikoff hepatomas. Cancer Res., 40: 1486-1492, 1980.

19. Boitier, E., Merad-Boudia, M., Guguen-Guillouzo, C., Defer, N., CeballosPicot, I., Leroux, J., and Marsac, C. Impairment of the mitochondrial respiratory chain activity in diethylnitrosamine-induced rat hepatomas: possible involvement of oxygen free radicals. Cancer Res., 55: 3028-3035, 1995.

20. Weber, K., Ridderskamp, D., Alfert, M., Hoyer, S., and Wiesner, R. J. Cultivation in glucose-deprived medium stimulates mitochondrial biogenesis and oxidative metabolism in HepG2 hepatoma cells. Biol Chem., 383: 283290, 2002.

21. Eigenbrodt, E., Kallinowski, F., Ott, M., Mazurek, S., and Vaupel, P. Pyruvate kinase and the interaction of amino acid and carbohydrate metabolism in solid tumors. Anticancer Res., 18: 3267-3274, 1998. 
22. Reitzer, L., Wice, B., and Kennel, D. Evidence that glutamine, not sugar, is the major energy source for cultured Hela cells. J. Biol. Chem., 254: 26692676, 1979.

23. Ishikawa, Y., Nakagawa, K., Satoh, Y., Kitagawa, T., Sugano, H., Hirano, T., Tsuchiya, E. Characteristics of chromate workers' cancers, chromium lung deposition and precancerous bronchial lesions: an autopsy study. $\mathrm{Br}$. J. Cancer, 70:160-166, 1994.

24. Deschamps, F., Moulin, J. J., Wild, P., Labriffe, H., Haguenoer, J. M. Mortality study among workers producing chromate pigments in France. Int. Arch. Occup. Environ. Health, 67:147-152, 1995.

25. Becker, N., Chang-Claude, J., Frentzel-Beyme, R. Risk of cancer for arc welders in the Federal Republic of Germany: results of a second follow up (1983-8). Br. J. Ind. Med., 48:675-683, 1991.

26. Nakagawa, K., Matsubara, T., Kinoshita, I., Tsuchiya, E., Sugano, H., Hirano, T. Surveillance study of a group of chromate workers - early detection and high incidence of lung cancer (in Japanese). Lung Cancer, 24:301-310, 1984.

27. Franchini, I., Magnani, F., Mutti, A. Mortality experience among chromplating workers. Scand. J. Work Environ. Health, 9:247-252, 1983.

28. Stern, R. M. Assessment of risk of lung cancer for welders. Arch. Environ. Health 38:148-155, 1983.

29. Connett, P., Wetterhahn, K. Metabolism of the carcinogenic chromate by cellular constituents. Struct Bonding, 54: 93-124, 1983.

30. Shi, X., Chiu, A., Chen, C.T., Halliwell, B., Castranova, V., Vallyathan, V., Reduction of chromium $(\mathrm{VI})$ and its relationship to carcinogenesis. J. Toxicol. Environ. Health B Crit. Rev., 2: 87-104, 1999.

31. Shi, X.L., Dalal, N.S., Chromium (V) and hydroxyl radical formation during the glutathione reductase-catalyzed reduction of chromium (VI). Biochem. Biophys. Res. Commun., 163: 627-634, 1989.

32. Shi, X.L., Dalal, N.S. Evidence for a Fenton-type mechanism for the generation of. $\mathrm{OH}$ radicals in the reduction of $\mathrm{Cr}(\mathrm{VI})$ in cellular media. Arch. Biochem. Biophys., 281: 90-95, 1990c. 
33. Ding, M., Shi, X. Molecular mechanisms of $\mathrm{Cr}(\mathrm{VI})$-induced carcinogenesis. Mol. Cell. Biochem., 234-235: 293-300, 2002.

34. Hodges, N.J., Adam, B., Lee, A.J., Cross, H.J., Chipman, J.K., Induction of DNA-strand breaks in human peripheral blood lymphocytes and A549 lung cells by sodium dichromate: association with 8-oxo-2-deoxyguanosine formation and interindividual variability. Mutagenesis, 16: 467-474, 2001.

35. Stohs, S.J., Bagchi, D., Hassoun, E., Bagchi, M., Oxidative mechanisms in the toxicity of chromium and cadmium ions. J. Environ. Pathol. Toxicol. Oncol., 19: 201-213, 2000.

36. Xu, J., Wise, J.P., Patierno, S.R.DNA damage induced by carcinogenic lead chromate particles in cultured mammalian cells. Mutat. Res., 280: 129-136, 1992.

37. Ye, J., Zhang, X., Young, H.A., Mao, Y., Shi, X. Chromium(VI)-induced nuclear factor-kappa $B$ activation in intact cells via free radical reactions. Carcinogenesis, 16: 2401-2405. 1995.

38. Zamzami, N., Marchetti, P., Castedo, M., Decaudin, D., Macho, A., Hirsch, T., Susin, S.A., Petit, P.X., Mignotte, B., Kroemer, G. Sequential reduction of mitochondrial transmembrane potential and generation of reactive oxygen species in early programmed cell death. J. Exp. Med., 182: 367-377, 1995.

39. Patierno, S.R., Banh, D., Landolph, J.R. Transformation of C3H/10T1/2 mouse embryo cells to focus formation and anchorage independence by insoluble lead chromate but not soluble calcium chromate: relationship to mutagenesis and internalization of lead chromate particles. Cancer Res., 48: 5280-5288, 1988.

40. Levy, L. S., Martin, P. A., and Bidstrup, P. L. Investigation of the potential carcinogenicity of a range of chromium containing materials on rat lung. $\mathrm{Br}$. J. Ind. Med., 43: 243-256, 1986.

41. Hanahan, D., Weinberg, R.A. The hallmarks of cancer. Cell, 100:57-70, 2000.

42. Buettner, G.R. ESR parameters of spin adducts. Free Rad. Biol. Med., 3: 259-303, 1987. 
43. Rogalska, A., Koceva-Chyla, A., Jozwiak, Z. Aclarubicin-induced ROS generation and collapse of mitochondrial membrane potential in human cancer cell lines. Chem. Biol. Interact., 176: 58-70, 2008.

44. Zhen, J., Lu, H., Wang, X.Q., Vaziri, N.D., Zhou, X.J. Upregulation of endothelial and inducible nitric oxide synthase expression by reactive oxygen species. Am. J. Hypertens., 21:28-34, 2008.

45. Freeman, B. A. and Crapo, J. D. Biology of disease: free radicals and tissue injury. Lab Invest., 47: 412-426, 1982.

46. Irani, K., Xia, Y., Zweier, J. L., Sollott, S. J., Der, C. J., Fearon, E. R., Sundaresan, M., Finkel, T., and Goldschmidt-Clermont, P. J. Mitogenic signaling mediated by oxidants in Ras-transformed fibroblasts. Science, 275 : 1649-1652, 1997.

47. Chen, Q., Vazquez, E. J., Moghaddas, S., Hoppel, C. L., and Lesnefsky, E. J. Production of reactive oxygen species by mitochondria: central role of complex III. J. Biol. Chem., 278: 36027-36031, 2003.

48. Ricci, J. E., Waterhouse, N., and Green, D. R. Mitochondrial functions during cell death, a complex (I-V) dilemma. Cell Death Differ., 10: 488-492, 2003.

49. Lubos, E., Loscalzo, J., Handy, D.E. Glutathione peroxidase-1 in health and disease: from molecular mechanisms to therapeutic opportunities. Antioxid. Redox. Signal., 2010.

50. Holley, A.K., Dhar, S.K., St. Clair, D.K. Manganese superoxide dismutase versus p53: the mitochondrial center. Ann. N. Y. Acad. Sci., 1201:72-8, 2010.

51. Liwei, L., Chunyu, L., Ruifa, H. Association between manganese superoxide dismutase gene polymorphism and risk of prostate cancer: a meta-analysis. Urology, 74:884-8, 2009.

52. Wang, S., Wang, F., Shi, X., Dai, J., Peng, Y., Guo, X., Wang, X., Shen, H., $\mathrm{Hu}, \mathrm{Z}$. Association between manganese superoxide dismutase (MnSOD) Val9Ala polymorphism and cancer risk - A meta-analysis. Eur. J. Cancer., 45:2874-81, 2009.

53. Lindsay, J., Esposti, M.D., Gilmore, A.P. Bcl-2 proteins and mitochondriaSpecificity in membrane targeting for death. Biochim. Biophys. Acta., 2010. 
54. Soriano ME, Scorrano L. The interplay between BCL-2 family proteins and mitochondrial morphology in the regulation of apoptosis. Adv. Exp. Med Biol., 687:97-114, 2010.

55. Lu, Y. Y. and Yang, J. L. Long-term exposure to chromium(VI) oxide leads to defects in sulfate transport system in Chinese hamster ovary cells. J Cell Biochem, 57: 655-665, 1995.

56. Freeman, B. A. and Crapo, J. D. Biology of disease: free radicals and tissue injury. Lab Invest, 47: 412-426, 1982.

57. Irani, K., Xia, Y., Zweier, J. L., Sollott, S. J., Der, C. J., Fearon, E. R., Sundaresan, M., Finkel, T., and Goldschmidt-Clermont, P. J. Mitogenic signaling mediated by oxidants in Ras-transformed fibroblasts. Science, 275 : 1649-1652, 1997.

58. Chen, Q., Vazquez, E. J., Moghaddas, S., Hoppel, C. L., and Lesnefsky, E. J. Production of reactive oxygen species by mitochondria: central role of complex III. J Biol Chem, 278: 36027-36031, 2003. 


\section{CHAPTER III}

Malignant Transformation and Tumorigenesis of Chromium (VI)-

Exposed Lung Cells and their Inhibition by Bcl-2 Knockdown 


\subsection{Abstract}

Environmental exposure to heavy metals such as hexavalent chromium $(\mathrm{Cr}(\mathrm{VI}))$ is associated with an increased incidence of human lung cancer. Elucidation of phenotypic changes, specific molecular effectors and their hierarchy in $\mathrm{Cr}(\mathrm{VI})$ induced carcinogenesis has been limited due to the lack of appropriate experimental models especially for long-term exposure studies. We have developed an in vitro-in vivo chronic exposure model for mechanistic studies of $\mathrm{Cr}(\mathrm{VI})$-induced carcinogenesis which is applicable to other xeno-carcinogenesis studies. Long-term exposure to $\mathrm{Cr}(\mathrm{VI})$ leads to malignant transformation of human lung epithelial BEAS-2B cells, as indicated by their increased cell migration, invasion, proliferation, and colony formation activities. $\mathrm{Cr}(\mathrm{VI})$ transformed cells induced tumorigenesis in nude mice comparable to that of well established human lung cancer $\mathrm{H} 460$ cells, whereas passage-matched control BEAS-2B cells showed no tumor development. To provide a mechanistic insight to the tumorigenic process, stable knockdown mutants of $\mathrm{Cr}(\mathrm{VI})$-transformed cells and $\mathrm{H} 460$ cells exhibiting downregulated $\mathrm{Bcl}-2$ phenotype were generated and evaluated for tumor associated properties in vitro and in vivo. The Bcl-2 knockdown mutants showed a substantial decrease in the rates of colony formation, invasion, migration and proliferation, as well as tumor formation in mice, in comparison to vector controls. These results indicate a novel role of Bcl2 , beyond apoptosis regulation, to be a key regulator of malignant transformation and tumorigenesis in vivo. The model described here may provide utility to other xeno-carcinogenesis studies, including those of heavy metals which currently lack effective in vivo tumor development experimental means. 


\subsection{Introduction}

Lung cancer is the leading cause of cancer mortality worldwide and yet the etiology of lung cancer is poorly understood. Current research indicates that long-term exposure to inhaled carcinogens has the greatest impact on the risk of lung cancer. $\mathrm{Cr}(\mathrm{VI})$ compounds are ubiquitous carcinogens associated with the incidence of lung cancer in humans. Several epidemiological studies in the last few decades have associated exposure to $\mathrm{Cr}(\mathrm{VI})$ with the induction of lung cancer in workers in various occupational settings (1-5). $\mathrm{Cr}(\mathrm{VI})$ compounds are also present in cigarette smoke, automobile emissions, and are widespread in the environment, e.g., $\mathrm{Cr}(\mathrm{VI})$-contaminated water. In the United States, an air quality survey indicated that people in several residential areas are exposed to particulate airborne chromium at concentrations exceeding 100 times the chronic toxicity benchmark (6). Therefore, in addition to occupational exposure, environmental chromium is an emerging concern for its associated long-term carcinogenic effect of the lungs.

Although several epidemiological studies have demonstrated the carcinogenic effect of $\mathrm{Cr}(\mathrm{VI})$ compounds, animal studies have yielded negative or inconsistent results (7-9) due to genetic variations or other predisposing factors that are not clearly understood. The lack of appropriate animal models has hindered the efforts to identify the mechanisms of $\mathrm{Cr}(\mathrm{VI})$-induced carcinogenesis; therefore, even though $\mathrm{Cr}(\mathrm{VI})$ compounds have been identified as human carcinogens (10), the underlying mechanisms remain poorly understood. To date, most $\mathrm{Cr}(\mathrm{VI})$ carcinogenesis studies have focused on short-term or acute effects; however, carcinogenesis is a multi-step process requiring long-term exposure to the carcinogen. To mimic the pathologic exposure condition, we developed an in vitro chronic exposure model combined with in vivo tumorigenesis model to aid mechanistic studies of $\mathrm{Cr}(\mathrm{VI})$-induced lung carcinogenesis. Using the combined model, we also investigated the potential role of $\mathrm{Bcl}-2$ in the carcinogenic process. 
$\mathrm{Bcl}-2$ is a key apoptosis-regulatory protein known to be important in the regulation of $\mathrm{Cr}(\mathrm{VI})$-induced apoptosis (11). Chronic exposure of lung epithelial cells to $\mathrm{Cr}(\mathrm{VI})$ led to apoptosis resistance and upregulation of Bcl-2 (12). Several apoptosis-resistant lung cell lines and tumor specimens have also been shown to overexpress Bcl-2 (13-15). This protein has also been shown to be upregulated in many forms of cancer, including $90 \%$ of colorectal cancer, $70 \%$ of breast cancer, and $30-60 \%$ of prostate cancer $(16,17)$. While these studies suggest the possible role of $\mathrm{Bcl}-2$ in $\mathrm{Cr}(\mathrm{VI})$-induced carcinogenesis, direct evidence for its role is lacking. In this study, we used a molecular approach to knockdown Bcl-2 and measured its effects on malignant transformation and tumorigenic properties of human lung epithelial cells chronically exposed to $\mathrm{Cr}(\mathrm{VI})$. We also used bioinformatics approach to aid the mechanistic investigations of Bcl-2's role in $\mathrm{Cr}(\mathrm{VI})$-induced carcinogenesis.

\subsection{Materials and Methods}

\section{Chemicals and Reagents}

Sodium dichromate $\left(\mathrm{Na}_{2} \mathrm{Cr}_{2} \mathrm{O}_{7} .2 \mathrm{H}_{2} \mathrm{O}\right)$ [Cr(VI)] was obtained from Sigma (St. Louis, MO). Hoechst 33342 were obtained from Molecular Probes (Eugene, OR). Lipofectamine was from InVitrogen (Carlsbad, CA). Antibodies for Bcl-2, $\beta$ actin, and peroxidase-conjugated secondary antibodies were from Santa Cruz Biotechnology (Santa Cruz, CA).

\section{Cell Culture}

Human lung epithelial BEAS-2B cells and human lung cancer epithelial H460 cells were obtained from American Type Culture Collection (Manassas, VA). BEAS-2B cells were cultured in Dulbecco's modified eagle medium containing $5 \%$ fetal bovine serum (FBS), $2 \mathrm{mM} \mathrm{L-glutamine,} 100$ units $/ \mathrm{ml}$ penicillin and streptomycin. H460 cells were cultured in RPMI 1640 medium containing 10\% 
FBS, $2 \mathrm{mM} \mathrm{L-glutamine,} 100$ units/ml penicillin and streptomycin in a $5 \% \mathrm{CO}_{2}$ environment at $37^{\circ} \mathrm{C}$.

\section{Chronic Cr(VI) Exposure}

BEAS-2B cells were continuously exposed to $5 \mu \mathrm{M} \mathrm{Cr}(\mathrm{VI})$ in culture in $5 \% \mathrm{CO}_{2}$ at $37^{\circ} \mathrm{C}$. The cells were passaged weekly at preconfluent densities using a solution containing $0.05 \%$ trypsin and $0.5 \mathrm{mM}$ EDTA. $\mathrm{Cr}(\mathrm{VI})$-exposed BEAS-2B cells are designated as BEAS-Cr cells so as to distinguish them from the parental BEAS2B cells. Parallel cultures grown in $\mathrm{Cr}(\mathrm{VI})$-free medium provided passagematched controls. After 24 weeks of exposure, $\mathrm{Cr}(\mathrm{VI})$-exposed cells were cultured in normal medium and their tumorigenic potential was assessed by various measurements below.

\section{Cell Growth Assay}

Cells $\left(1 \times 10^{5}\right.$ cells) were seeded on $60-\mathrm{mm}$ cell culture dishes and were incubated at $37^{\circ} \mathrm{C}$ in a $5 \% \mathrm{CO}_{2}$ incubator. At specific times after the incubation, cells were trypsinized and analyzed for cell number using Countess ${ }^{\circledR}$ automated cell counter (InVitrogen, Carlsbad, CA).

\section{Soft Agar Colony Formation Assay}

Soft agar assay was performed as previously described with minor modifications (18). The cell lines studied $\left(3 \times 10^{4}\right.$ cells) were mixed with tissue culture medium containing $0.5 \%$ agar to result in a final agar concentration of $0.33 \%$. Cell suspension $(1.5 \mathrm{ml})$ was plated in $60-\mathrm{mm}$ dishes coated with $7 \mathrm{ml}$ of $0.5 \%$ agar in tissue culture medium. After 2 weeks, the average number of colonies with a diameter of more than 50 cells was scored under a light microscope.

Invasion Assay

Invasion assays were performed using Transwell invasion chambers coated with Matrigel (50 $\mu$ l per filter) (BD, USA) according to the manufacturer's protocol. Cells were cultured for $48 \mathrm{~h}$ and transferred on the top of Matrigel-coated 
invasion chambers in a serum-free medium ( $1 \times 10^{5}$ cells per Transwell). Medium containing 5\% FBS was added to the lower chambers. After incubation for $24 \mathrm{~h}$, cells that remained on the top of the filter were scrubbed off and cells that migrated to the lower surface were fixed in $90 \%$ alcohol and followed by a crystal violet stain.

\section{Migration Assay}

Cell migration was determined by wound assay. Cells were cultured in 24-well plate and then a wound space was made with $1 \mathrm{~mm}$ width tip. Cells were incubated under standard conditions for $24 \mathrm{~h}$, after which they were washed and examined under a light microscope. Analysis of cell migration was performed by using an average wound space from ten random fields of view, and the percentage of change in the wound space was calculated using the formula: $\%$ change $=($ average space at time $0 \mathrm{~h})-($ average space at time $24 \mathrm{~h}) /($ average space at time $0 \mathrm{~h}) \times 100$. Relative cell migration was calculated by dividing the percentage change in the wound space of indicated cells by that of the control cells in each experiment.

\section{Generation of Bcl-2 Knockdown Clones}

Lentiviral transduction particles carrying short hairpin RNA (shRNA) sequence against human Bcl-2 (5'-CCGGGTGATGAAGTACATCCATTATCTCGAGATAAT GGATGTACTTCATCACTTTTG-3') and control non-target sequence (5'-CCGGC AACAAGATGAAGAGCACCAACTCGAGTTGGTGCTCTTCATCTTGTTGTTTTT3') were used to knockdown Bcl-2 expression in BEAS-Cr and $\mathrm{H} 460$ cells. The viral vectors were obtained from Sigma (Cat \# SHVRS-NM_000633 and

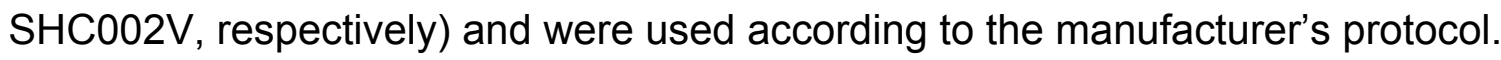
Briefly, the cells were seeded in 6 -well plates $\left(5 \times 10^{5} /\right.$ well) and incubated with $\mathrm{Bcl}-2$ shRNA lentiviral particles or control particles at the multiplicity of infection (MOI) of 1.5 in the presence of hexadimethrine bromide $(8 \mu \mathrm{g} / \mathrm{ml})$ for $36 \mathrm{~h}$. For generation of stable clones, cells were plated onto $10-\mathrm{cm}$ dishes and cultured for $14 \mathrm{~d}$ with puromycin $(1 \mu \mathrm{g} / \mathrm{ml})$. Resistant clones expressing varying levels of Bcl- 
2 were isolated using cloning cylinders (Bellco Glass, Vineland, NJ) and transferred for expansion and analysis by Western blotting.

\section{Western Blotting}

Cells were incubated in a lysis buffer for 20 min on ice. After centrifugation at $14,000 \mathrm{~g}$ for $15 \mathrm{~min}$ at $4^{\circ} \mathrm{C}$, cell supernatants were collected and assayed for protein content. Equal amounts of protein per sample $(15 \mu \mathrm{g})$ were resolved on $10 \%$ sodium dodecyl sulfate-polyacrylamide gel electrophoresis and transferred onto $0.45-\mu \mathrm{m}$ nitrocellulose membranes. The transferred membranes were blocked for $1 \mathrm{~h}$ in $5 \%$ non-fat dry milk in TBST $(25 \mathrm{mM}$ Tris- $\mathrm{HCl}, \mathrm{pH} 7.4,125 \mathrm{mM}$ $\mathrm{NaCl}, 0.05 \%$ Tween-20) and incubated with appropriate primary antibodies, followed by horseradish peroxidase-conjugated secondary antibodies. The immune complexes were detected by chemiluminescence (Supersignal ${ }^{\circledR}$ West Pico, Pierce Biotechnology, Rockford, IL) and quantified by imaging densitometry using UN-SCAN-IT automated digitizing software (Silk Scientific, Orem, UT). Mean densitometry data from independent experiments were normalized to the control.

\section{In Vivo Tumor Xenograft Model}

Athymic (nu/nu) male nude mice, obtained from Jackson Laboratory (Bar Harbor, $M E$ ), were housed under pathogen-free conditions and fed autoclaved diet and water ad libitum. To establish tumor xenografts in mice, BEAS-2B, BEAS-Cr, $\mathrm{H} 460$ and $\mathrm{Bcl}-2$ knockdown cells $\left(1 \times 10^{6}\right.$ cells) were suspended in 1:1 medium mixed with Matrigel and were injected subcutaneously on the left and right flanks of each mouse. Tumor size was measured at $14 \mathrm{~d}$ post-injection by using a caliper, and the tumor volume was determined using the formula: $0.5238 \times \mathrm{L}$ (length) $\times \mathrm{W}$ (width) $\times \mathrm{H}$ (height) of the tumor. All procedures were conducted in accordance with the guidelines for the Use and Care of Laboratory Animals and approved by the Institutional animal care and use committee.

Bcl-2 Interactome Analysis 
The Ingenuity Pathways Analysis (IPA) software (Ingenuity Systems, Redwood City, CA) was used to analyze currently published Bcl-2 interactome. The Ingenuity database is the largest curated database of previously published findings on mammalian biology from the public literature (i.e., MEDLINE). Reports on individual studies of genes in human, mouse or rat were first identified from peer-reviewed publications, and findings were then encoded into ontology by content and modeling experts. Network analysis using the knowledge base was used to further identify direct interactions between mammalian orthologues. The Bcl-2-interactome is a graphical representation of its published molecular relationships. Molecules are represented as nodes, and the biological relationship between two nodes is represented as an edge (line). Nodes are displayed using various shapes that represent the functional class of the gene product. Edges are displayed with various labels that describe the nature of the relationship between the nodes.

\section{Statistical Analysis}

The data were expressed as means \pm SD of three or more independent experiments. Statistical analysis was performed using two-tailed and paired Student's t-test. $P$ values less than 0.05 were considered statistically significant and indicated by an asterisk.

\subsection{Results}

\section{Cell Growth and Colony Formation}

BEAS-2B cells were continuously exposed to $\mathrm{Cr}(\mathrm{VI})$ for 24 weeks in culture as described in Materials and Methods. In order to assess the relative tumorigenic potential of the exposed cells (BEAS-Cr), we compared their growth and colony formation characteristics to those of the passage-matched BEAS-2B cells serving as a negative control, and human lung carcinoma $\mathrm{H} 460$ cells serving as a positive control. The BEAS-2B cell line has been used previously to study the carcinogenic potential or effects of various chemicals and biological agents (19- 
21). The $\mathrm{H} 460$ cell line has been evaluated extensively in mechanistic studies of human lung cancer. Statistically significant increase in growth capacities was observed as early as $48 \mathrm{~h}$ in BEAS-Cr and $\mathrm{H} 460$ cells as compared to control BEAS-2B cells (Figures $1 A-B$ ). By $96 \mathrm{~h}$, the growth rates of BEAS-Cr and $\mathrm{H} 460$ cells were more than double that of the control BEAS-2B cells. Next, soft agar colony formation assay was performed to assess relative colony formation capacities. BEAS-2B, BEAS-Cr, and $\mathrm{H} 460$ cells were subjected to colony formation assay by growing them on agar plates so as to assess anchorageindependent growth. After 2 weeks, significant colony formation was observed in BEAS-Cr cells with a 7-fold increase as compared to passage-control BEAS-2B cells which also formed very few, slow growing colonies (Figures 1C-D). The H460 human lung cancer cells exhibited the highest colony formation capacity, out-growing the BEAS-2B cells by approximately 8 -fold and BEAS-Cr cells by approximately 1.5 -fold.

\section{Migration and Invasion}

We next investigated the relative, aggressive-malignant phenotype, capacities using the same comparative approach. The $\mathrm{H} 460$ cells showed the highest invasion capacity with BEAS-Cr cells invading at the rate of $70 \%$ relative to $\mathrm{H} 460$, and BEAS-2B invading at $15 \%$ (Figures $2 \mathrm{~A}-\mathrm{B}$ ). A 7 -fold increase in invasion rate was observed in BEAS-Cr as compared to BEAS-2B cells. The highest migration capacity was observed in $\mathrm{H} 460$ cells followed by BEAS- $\mathrm{Cr}$ cells, at approximately $75 \%$ of $\mathrm{H} 460$ cells, and finally, BEAS-2B cells, at less than $10 \%$ of $\mathrm{H} 460$ cells (Figures $2 \mathrm{C}-\mathrm{D}$ ). Together, these studies indicate that chronic exposure of non-tumorigenic BEAS-2B cells induced malignant transformation of the cells showing phenotypic characteristics similar to those of the tumorigenic $\mathrm{H} 460$ cells.

\section{Bcl-2 Expression and Sensitivity to $\mathrm{Cr}(\mathrm{VI})$}

Apoptosis is the primary mode of cell death following an insult with $\mathrm{Cr}(\mathrm{VI})$ at physiologically relevant doses $(11,22)$. Apoptosis resistance, on the other hand, 
is the central objective of "one renegade cell" on its quest toward malignancy. Previous studies have shown that Bcl-2 is a key protein involved in apoptosis resistance to $\mathrm{Cr}(\mathrm{VI})(11,12)$. Whether this is a mechanistic feature unique to specific cell systems or a more general feature of carcinogenesis is uncertain. To test this possibility, we evaluated endogenous $\mathrm{Bcl}-2$ protein expression across our 3 cell type comparative system using Western blots. The results show that BEAS-Cr cells exhibited a substantial higher amount of Bcl-2 relative to that of passage-control BEAS-2B cells, but comparable to that of H460 cells (Figure $3 \mathrm{~A})$. In response to acute $\mathrm{Cr}(\mathrm{VI})$ treatment, $\mathrm{Bcl}-2$ protein expression was substantially downregulated in BEAS-2B cells, and to a much lesser extent in BEAS-Cr and H460 cells (Figure 3B), suggesting a mechanistic similarity between the latter two cell types.

\section{Bcl-2 Knockdown Effect in Vitro}

Mutant cell lines exhibiting stably downregulated $\mathrm{Bcl}-2$ were generated using RNA interference and clonal selection. Maximum Bcl-2 downregulation in BEASCr mutants (85\%) was achieved in clone 2, which was used for the remainder of the study (Figure 4A). H460 clone 1 showed $75 \%$ Bcl-2 reduction and was used for further study. Scramble sequences were used to generate appropriate controls for the BEAS-Cr and $\mathrm{H} 460$ mutant cells. Downregulation of $\mathrm{Bcl}-2$ reduced proliferation rates of both BEAS-Cr and $\mathrm{H} 460$ cells by about $50 \%$ at $96 \mathrm{~h}$ (Figure 4B). Next, the effect of Bcl-2 knockdown on colony formation capacity was evaluated. The BEAS-Cr mutant exhibited approximately $60 \%$ reduction in colony formation while a $40 \%$ reduction was observed in the $\mathrm{H} 460$ mutant as compared to their respective controls (Figure 4C). The trend continued when migration and invasion capacities were assessed with both mutants showing significant decrease in these tumor-associated properties compared to controls (Figures 4D-E).

\section{Bcl-2 Knockdown Effect In Vivo}


To assess the potential tumorigenicity of $\mathrm{Cr}(\mathrm{VI})$-transformed BEAS-Cr cells and role of $\mathrm{Bcl}-2$ in the tumorigenic process, experiments were performed using a xenograft mouse model. The cells and their knockdown mutants were subcutaneously injected into nude mice. At one week after the injection, small tumors were formed at the injection site in mice receiving BEAS-Cr and $\mathrm{H} 460$ cells, whereas mice receiving BEAS-2B cells did not develop tumors. At 14 days post-injection, large tumors were found in the BEAS-Cr (Figure 5A) and $\mathrm{H} 460$ (Figure 5B) mice, whereas no or very small lumps were observed in the BEAS2B control mice. To our knowledge, this is the first demonstration of in vivo tumorigenesis with $\mathrm{Cr}(\mathrm{VI})$-transformed cells. Mice receiving Bcl-2 knockdown mutants, either BEAS-Cr or $\mathrm{H} 460$, showed a substantial reduction in tumor volume as compared to their respective controls (Figures 5A-B). These results indicate the role of $\mathrm{Bcl}-2$ in tumorigenesis of $\mathrm{Cr}(\mathrm{VI})$-transformed cells. The inhibition of tumor growth in $\mathrm{H} 460$ mutant mice also implicates the general role of $\mathrm{Bcl}-2$ in tumorigenesis of lung cancer cells.

\section{Bcl-2 Interactome Analysis}

In order to establish a strategy towards a better understanding of the mechanism(s) involved in Bcl-2's contribution to carcinogenesis, we performed an extensive PubMed database search for possible molecular targets. The initial query for Bcl-2 returned 33,970 hits! We realized that other approaches may need to be evaluated given the complexity of $\mathrm{Bcl}-2$ cellular role(s). Following the analysis of available options, we turned to Ingenuity Pathways Analysis (IPA). IPA integrates the primary literature into easily searched and visualized networks allowing for orders of magnitude faster evaluation of cellular signaling cascades. Figure 6A shows the initial IPA query of Bcl-2's interactions reported to date (IPA v8.6). 741 molecules have thus far been reported to interact with Bcl-2 either directly or indirectly. In order to make the network more relevant to our model, we filtered for only those interactions reported in humans (Figure 6B). This reduced the interaction network to 56 molecules organized by cellular localization (Bcl-2-interactome). Given that we selectively targeted Bcl-2 and observed 
significant consequences on tumor-associated properties, we asked IPA to map only the downstream components of human Bcl-2-interactome (Figure $6 \mathrm{C}$ ). The query returned 20 molecules. As we progressed from Figure $6 \mathrm{~A}$ overwhelming complexity to Figure $6 \mathrm{C}$, the current mechanistic evidence of Bcl-2's role in carcinogenesis emerged, as did a new approach to scientific query.

\subsection{Discussion}

Although $\mathrm{Cr}(\mathrm{VI})$ has been identified as a potent human carcinogen, the mechanism underlying the carcinogenic process remains unclear due in part to the lack of appropriate experimental models for long-term exposure studies. In this study, we reported a combined in vitro-in vivo model for $\mathrm{Cr}(\mathrm{VI})$ carcinogenesis studies using chronically exposed bronchial epithelial BEAS-2B cells and a mouse tumorigenesis model. Bronchial epithelial cells were chosen in this study because they are a key target for $\mathrm{Cr}(\mathrm{VI})$-induced carcinogenesis. BEAS-2B cells have been widely used in the literature to define conditions under which various agents and oncogenes cause neoplastic transformation (19-21). Inclusion of the passage-control BEAS-2B cells and bronchial carcinoma H460 cells into direct comparisons was critical when assessing the significance of tumorigenic properties in the evolved BEAS-Cr phenotype. H460 cells are a well established model for in vitro and in vivo mechanistic studies of lung carcinogenesis and therefore represent a positive control. For BEAS-Cr cells, significant growth increase was observed as early as $48 \mathrm{~h}$ and at $96 \mathrm{~h}$ the growth rate was double that of control BEAS-2B cells (Figures 1A-B). H460 cells proliferated even faster, at approximately 2.5 times that of BEAS-2B cells. This could be in part due to $10 \%$ serum content of standard culture medium for $\mathrm{H} 460$ cells vs. $5 \%$ for BEAS-2B and BEAS-Cr cells. We performed a series of direct comparisons with all cell lines cultured at $5 \%$ serum and observed a slight decrease in $\mathrm{H} 460$ cell growth (data not shown), however we opted to continue at $10 \%$ since it is the literature standard. 
Anchorage-dependent growth is a typical feature of normal cells and controls cell division (23), however when cells are transformed they lose this property. Anchorage-independent growth has been widely correlated with tumorigenicity and invasiveness in several cancer cell types (23). Soft agar assay is a stringent test to study the ability of cells to undergo anchorage-independent growth. The number of colonies formed by BEAS-Cr cells was about 7 times more than that in control BEAS-2B cells, confirming the carcinogenic potential of $\mathrm{Cr}(\mathrm{VI})$ transformed cells (Figures 1C-D). H460 cells formed colonies at even higher rate, exceeding BEAS-Cr cells by about $30 \%$. Interestingly, bronchial epithelial BEAS-2B cells obtained at autopsy of non-cancerous individuals also formed a small number of slow growing colonies on soft agar. This could be due to the fact that BEAS-2B cells are reported to possess mutated and dysfunctional p53 tumor suppressor gene $(19,24)$. Additionally, the American Type Culture Collection (ATCC) indicates that the BEAS-2B cell line forms colonies in semisolid medium but is non-tumorigenic in immunosuppressed mice. Therefore, the colony formation observed in BEAS-2B cells is due to the indigenous properties of the cell and not because of their tumorigenic potential. $\mathrm{Cr}(\mathrm{VI})$-transformed cells were further characterized for their invasive and migratory properties and compared to those of established lung cancer $\mathrm{H} 460$ cells. Invasion and migration were shown to increase significantly as compared to passage-control BEAS-2B cells (Figures 2A-B). Recent reports indicate that BEAS-2B are non-tumorigenic, aneuploid cells but can undergo squamous differentiation in response to serum and transforming growth factor- $\beta$ (25). However, since passage-control BEAS-2B cells showed no phenotypic changes or malignant behavior, it can be concluded that BEAS-Cr cells are $\mathrm{Cr}(\mathrm{VI})$ transformed BEAS-2B cells and not BEAS-2B cells that have undergone differentiation and show altered phenotype due to continued passaging.

Carcinogenesis is a multistep process involving progressive transformation of normal cells into malignant phenotypes along with the aberrant accumulation of such abnormal cells $(26,27)$. $\mathrm{Cr}(\mathrm{VI})$ may affect the carcinogenic process during 
malignant transformation, i.e., by causing DNA mutation and damage, or aberrant cell accumulation, i.e., through evasion of apoptosis. Sensitivity to apoptosis depends on the expression level of various apoptosis-regulatory proteins. A functional loss of pro-apoptotic proteins and/or increased expression of anti-apoptotic proteins can confer resistance to apoptotic stimuli $(28,29)$. Bcl2 is a key anti-apoptotic protein involved in the apoptosis resistance to $\mathrm{Cr}(\mathrm{VI})$ (11). A lesser known function of $\mathrm{Bcl}-2$ is its tumorigenic properties. $\mathrm{Bcl}-2$ expression has been reported to be elevated in many forms of cancer (13-17) and was found in this study to be upregulated in $\mathrm{Cr}(\mathrm{VI})$-transformed BEAS-Cr cells (Figure $3 \mathrm{~A}$ ). In order to evaluate the potential relationship between $\mathrm{Bcl}-2$ and tumorigenic properties, gene knockdown experiments were performed to allow direct assessment of the Bcl-2's contribution to tumorigenic phenotype of BEAS-Cr and $\mathrm{H} 460$ cells. Our results show that $\mathrm{Bcl}-2$ knockdown leads to significant reduction of all tumorigenic properties evaluated (Figures $4 A-E$ ). While Bcl-2 is a well established oncogene, its 'oncogene' status is largely attributed to the evolution of chemoresistance via modulation of cell's apoptotic machinery. To the best of our knowledge, this is the first demonstration of Bcl2's role in carcinogenesis well beyond apoptosis regulation to that of "master" oncogene. Our in vivo data (Figures 5A-B) confirm this assertion. We show that $\mathrm{Cr}(\mathrm{VI})$-transformed BEAS-Cr cells form large tumors in nude mice, whereas control BEAS-2B cells do not. This is the first report of $\mathrm{Cr}(\mathrm{VI})$-transformed cells exhibiting such in vivo properties. Furthermore, downregulation of $\mathrm{Bcl}-2$ led to a substantial reduction of tumor volume in BEAS-Cr derived tumors. This mechanistic feature was nearly identical in human lung cancer H460 cells' derived tumors, indicating a potential shared mechanism between laboratory $\mathrm{Cr}(\mathrm{VI})$-induced carcinogenesis and human lung cancer.

Finally, Ingenuity Pathways Analysis revealed the known Bcl-2-interactome containing 56 molecules and 56 relationships identified as of IPA v8.6 (Figure $6 B)$. Given that we were interested in mechanisms underlying the effects observed following the downregulation of Bcl-2, we chose to focus on Ingenuity's 
output of known downstream effectors of Bcl-2-interactome (Figure 6C). Did any of the molecules listed have a link to regulation of tumor-associated properties such as proliferation, transformation, migration, invasion and colony formation? Analysis of Ingenuity Knowledge Base (IKB) strongly suggests YES. Out of all downstream Bcl-2 effectors, nucleus-localized constituents strongly argue that Bcl-2's role in carcinogenesis exceeds that of apoptosis regulation in line with our observations. Cyclin-dependent kinases 1 and 2 (CDK1\&2) regulate cell cycle progression, cellular motility and proliferation according to IKB summary of over 6,000 categorized literature findings. Their role in carcinogenesis is well established. Next, telomerase (TERT) is an established positive regulator of cell proliferation, immortalization and transformation. Its role in carcinogenesis is widely accepted. Of interest, RAD9A, implicated in the regulation of colony formation also appears in the IPA's output. Relative to its "neighbors", it is a less studied protein with only 380 categorized literature findings in the IKB. Lastly, vascular endothelial growth factor (VEGF) is a well established positive regulator of angiogenesis and is a downstream target of $\mathrm{Bcl}-2$. Its role in $\mathrm{Cr}(\mathrm{VI})$-induced carcinogenesis has not been demonstrated but is implicated by our study. In conclusion, evidence presented in this report suggests Bcl-2's role in carcinogenesis is much more than apoptosis evasion to that of apoptosisproliferation network hub regulator. Animal and in vitro data support its role in $\mathrm{Cr}(\mathrm{VI})$-induced tumorigenesis and malignant transformation. The reported experimental models may be used to aid mechanistic studies of other carcinogens. 
Figure 1
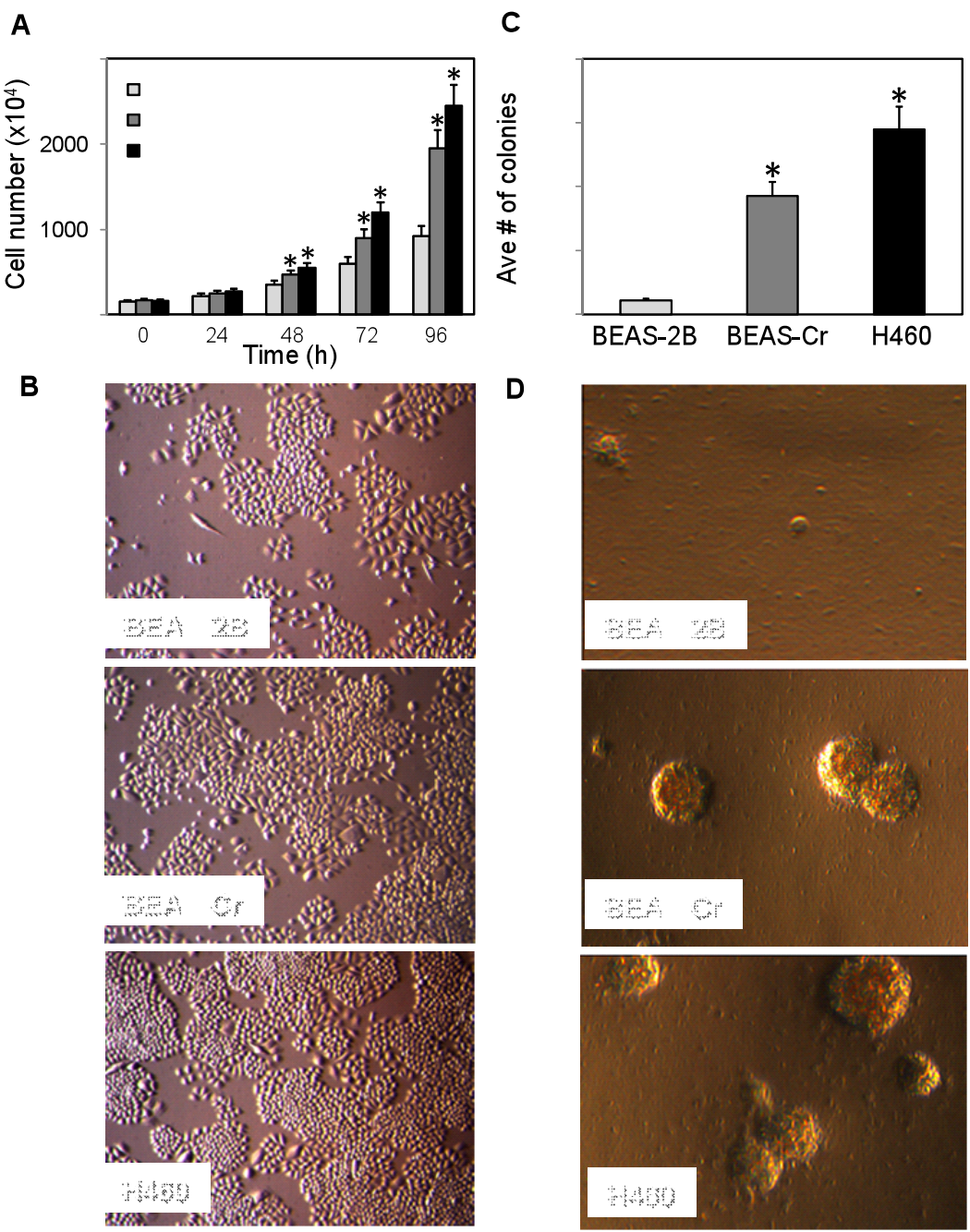

FIGURE 1. Cell growth and colony formation capacities of BEAS-2B, BEAS-Cr and $\mathbf{H} 460$ cells. $A, B E A S-2 B, B E A S-C r$ and $\mathrm{H} 460$ cells $\left(1 \times 10^{5}\right.$ cells) were seeded on $60-m m$ cell culture dishes and were incubated at $37^{\circ} \mathrm{C}$ in a $5 \% \mathrm{CO}_{2}$ incubator. At the indicated times, cells were trypsinized and analyzed for cell number using an electronic cell counter. $B$, Representative light micrographs of BEAS-2B, BEAS-Cr and $\mathrm{H} 460$ cells in culture at $96 \mathrm{~h}$ are shown. $C, B E A S-2 B$, BEAS- $\mathrm{Cr}$ and $\mathrm{H} 460$ cells $\left(3 \times 10^{4}\right.$ cells) were seeded on $0.5 \%$ agar plates and were incubated at $37^{\circ} \mathrm{C}$ in a $5 \% \mathrm{CO}_{2}$ incubator. After 2 weeks, colony formation capacity was scored under a light microscope. $D$, Representative micrographs of colonies formed by BEAS-2B, BEAS-Cr and $\mathrm{H} 460$ cells on soft agar are shown. Values are mean \pm S.D. $(n=4) .{ }^{*} p<0.05$ versus passage-control BEAS-2B cells. 
Figure 2
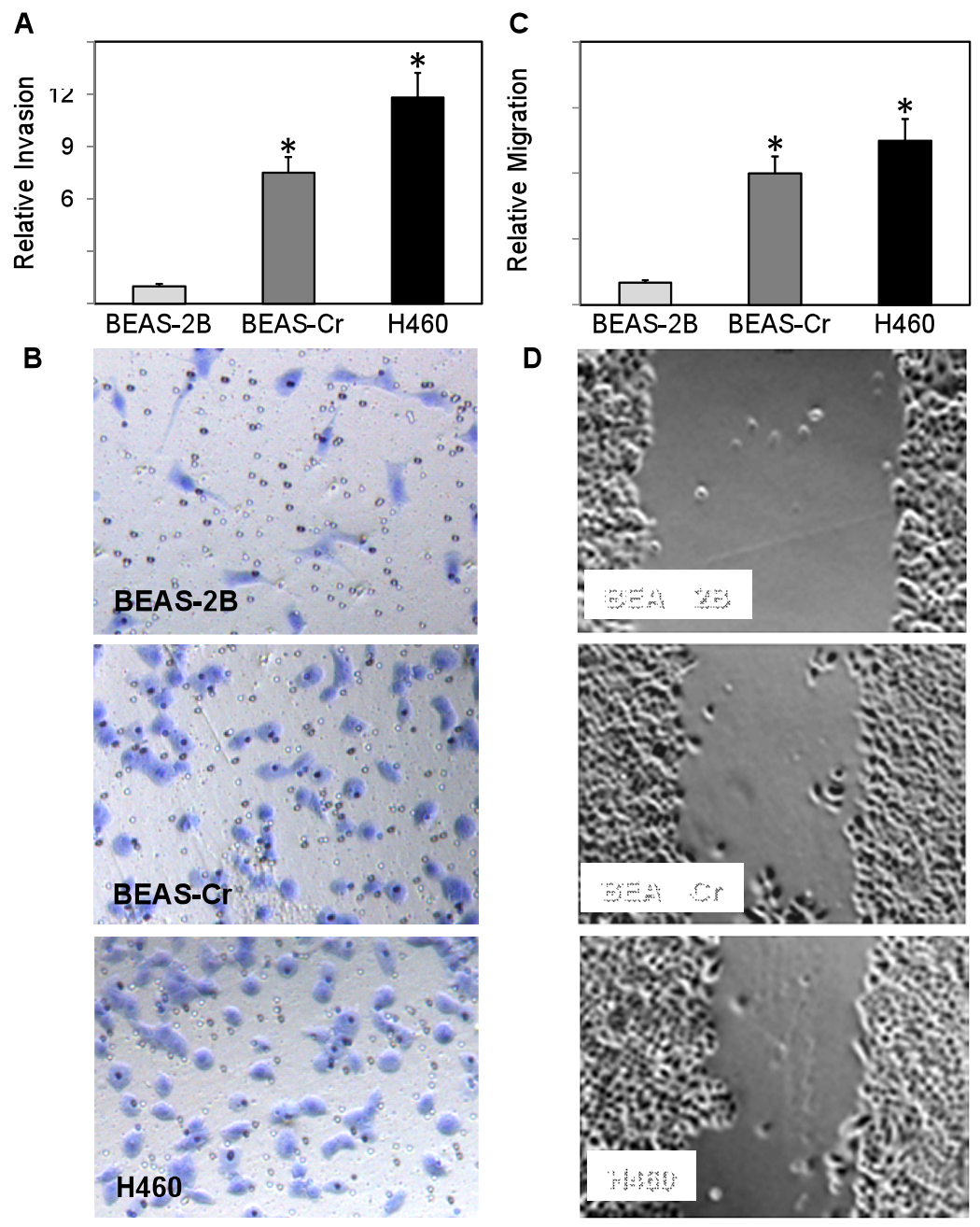

FIGURE 2. In vitro relative malignant phenotype capacities of BEAS-2B, BEAS-Cr and $\mathbf{H 4 6 0}$ cells. A, BEAS-2B, BEAS-Cr and $\mathrm{H} 460$ cells $\left(1 \times 10^{5}\right.$ cells) were added to Transwell inserts coated with Matrigel and incubated for $24 \mathrm{~h}$. Invading cells were stained and counted under a light microscope. Plots show relative invasion of BEAS-2B, BEAS-Cr and $\mathrm{H} 460$ cells. $B$, Representative micrographs of cells stained for invasion are shown. $C$, Confluent monolayers of BEAS-2B, BEAS-Cr and $\mathrm{H} 460$ cells were wounded, and the cells were allowed to migrate for 24 h. Wound space was visualized under a phase-contrast microscope and analyzed by comparing the relative change in wound space as compared to control cell monolayers. $D$, Representative micrographs of cells migrating from the wound edge are shown. Values are mean \pm S.D. $(n=4)$. ${ }^{*} p<0.05$ versus passage-control BEAS-2B cells. 
Figure 3
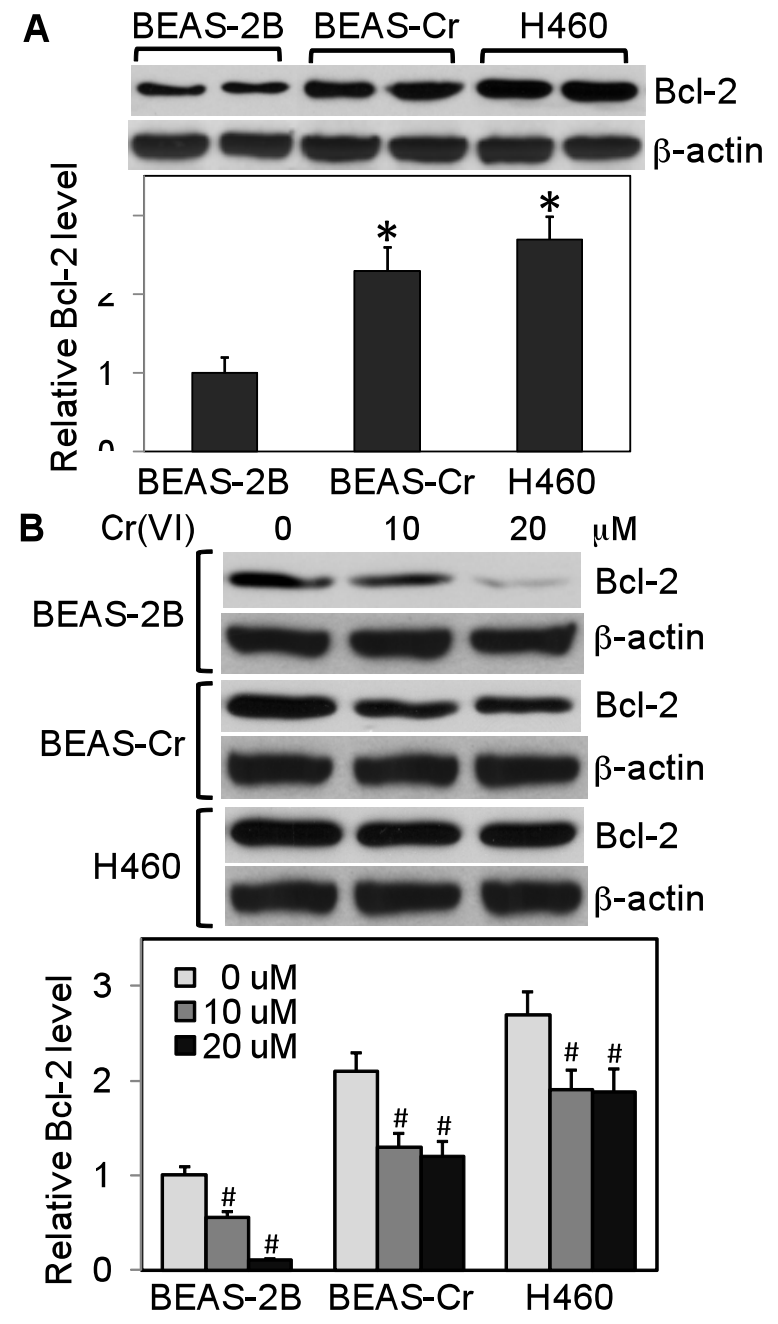

FIGURE 3. Bcl-2 expression and response to $\mathrm{Cr}(\mathrm{VI})$ treatment in BEAS-2B, BEAS-Cr and H460 cells. $A$, Endogenous Bcl-2 levels in BEAS-2B, BEAS-Cr and $\mathrm{H} 460$ cells determined by Western blotting. Densitometry was performed to determine the relative $\mathrm{Bcl}-2$ levels after reprobing the membrane with $\beta$-actin antibody. $B$, Cells were either left untreated or treated with $\mathrm{Cr}(\mathrm{VI})(10,20 \mu \mathrm{M})$ for $12 \mathrm{~h}$. Cell lysates were prepared and analyzed for $\mathrm{Bcl}-2$ by Western blotting. Values are mean \pm S.D. $(n=4) .{ }^{*} p<0.05$ versus passage-control BEAS-2B cells; ${ }^{*} p<$ 0.05 versus non-treated control of the respective cells. 
Figure 4

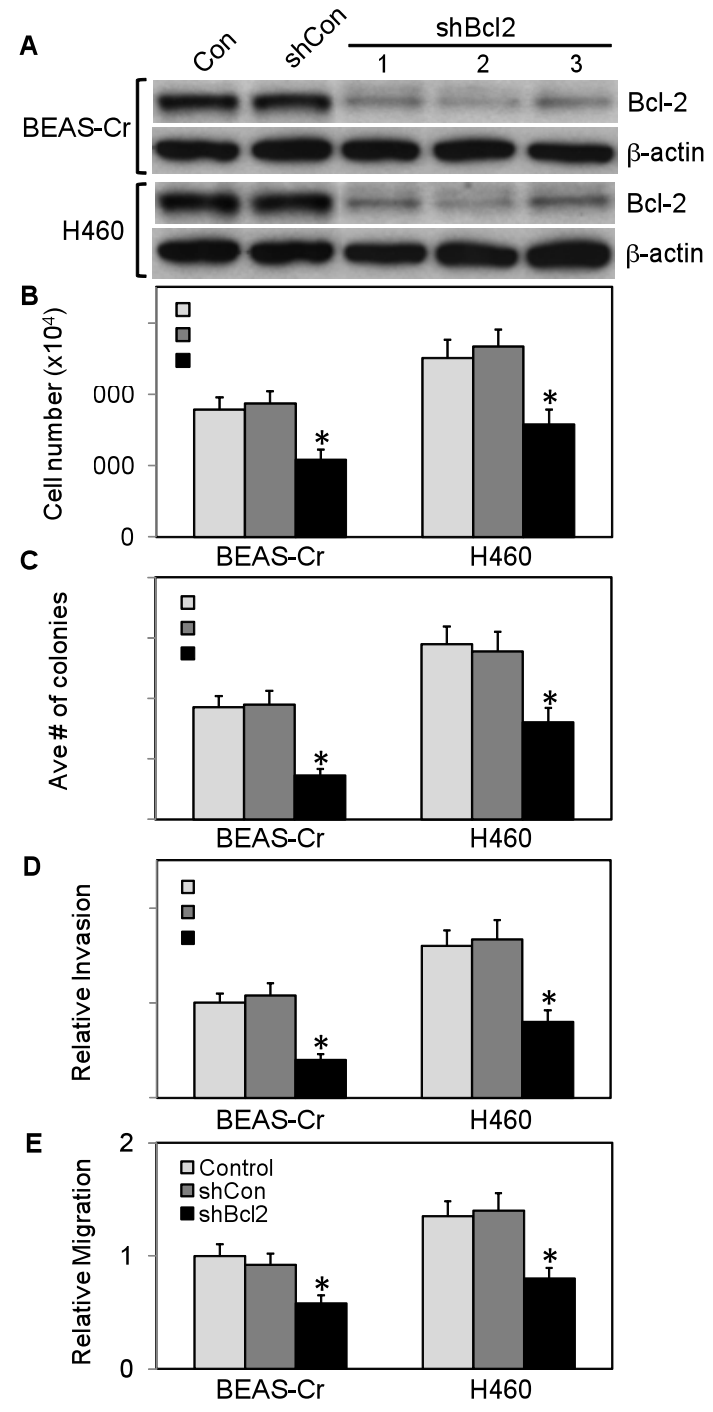

FIGURE 4. Effect of Bcl-2 knockdown on tumor-associated properties in vitro. A. Bcl-2 knockdown experiments were performed in BEAS-Cr and $\mathrm{H} 460$ cells by infecting the cells with Bcl-2 shRNA (shBcl-2) viral particles or control shRNA (shCon) particles as described in "Materials and Methods". Clonal selection and Bcl-2 expression were performed to identify mutants with downregulated $\mathrm{Bcl}-2$. B, Effect of $\mathrm{Bcl}-2$ on in vitro cell growth of the respective cell lines and their mutants. Cells $\left(1 \times 10^{5}\right.$ cells $)$ were seeded and incubated at $37^{\circ} \mathrm{C}$ for $96 \mathrm{~h}$, after which they were analyzed for cell number. $C$, Cells $\left(3 \times 10^{4}\right.$ cells) were seeded on soft agar plates and the colonies were scored after 2 weeks. $D$, Invasion assays were performed using Transwell invasion chambers as described. $E$, Cell migration was determined by wound assay as described. Values are mean \pm S.D. $(n=3) .{ }^{*} p<0.05$ versus passage-control BEAS-2B cells or shCon cells. 
Figure 5
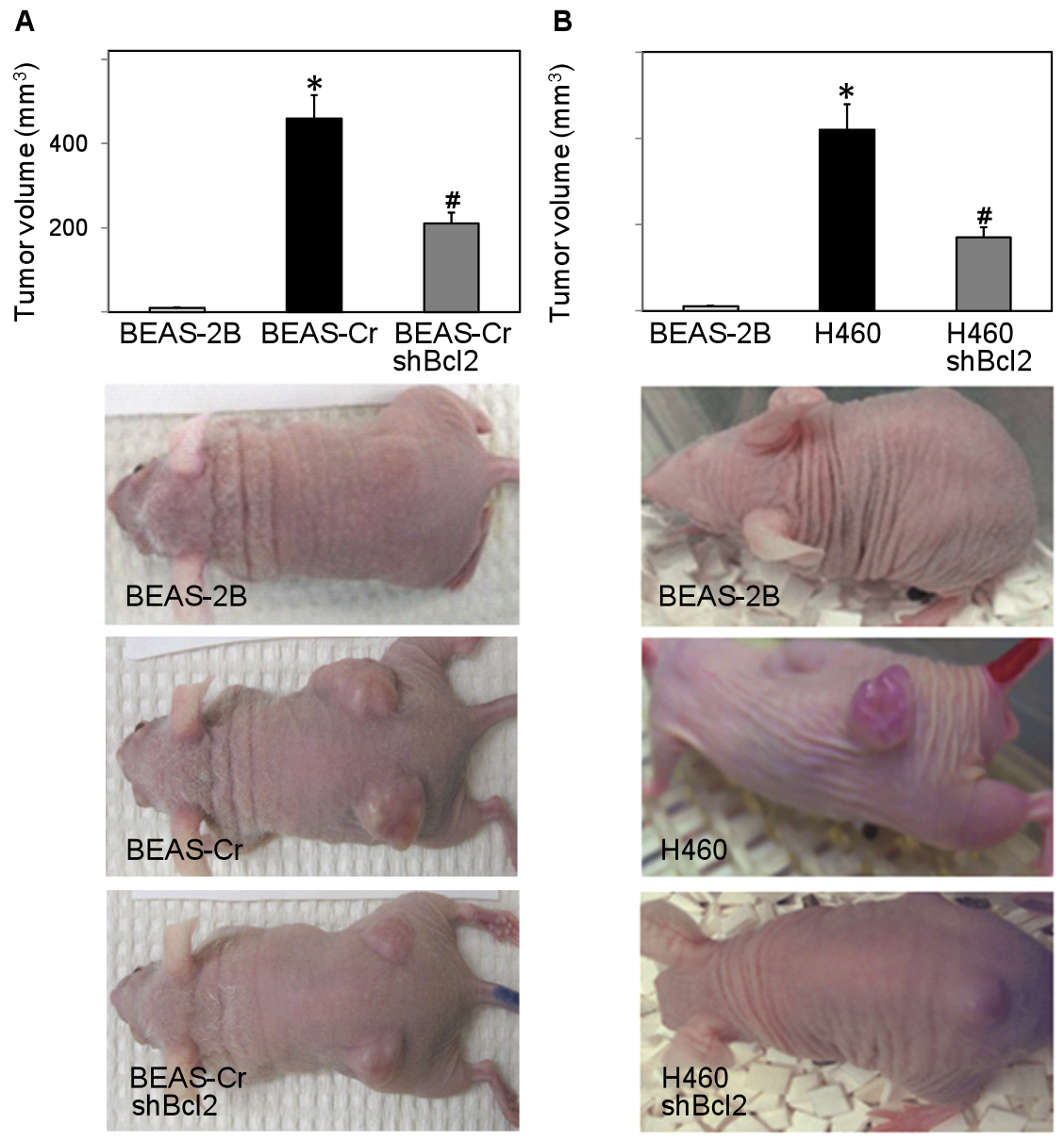

FIGURE 5. Effect of Bcl-2 knockdown on tumor-associated properties in vivo. $A$, Mice were injected subcutaneously with $1 \times 10^{6}$ passage-control BEAS-2B, BEAS-Cr, or shBcl-2 BEAS-Cr mutant cells. Tumor formation was determined at $14 \mathrm{~d}$ post-injection. Representative photographs are shown. B, Mice were similarly injected with control BEAS-2B, H460, or shBcl-2 H460 cells. Tumor formation and representative micrographs at $14 \mathrm{~d}$ post-injection are shown. Data are means \pm S.D. $(n=4) .{ }^{*} p<0.05$ vs. passage-control BEAS-2B cells. 
Figure 6A

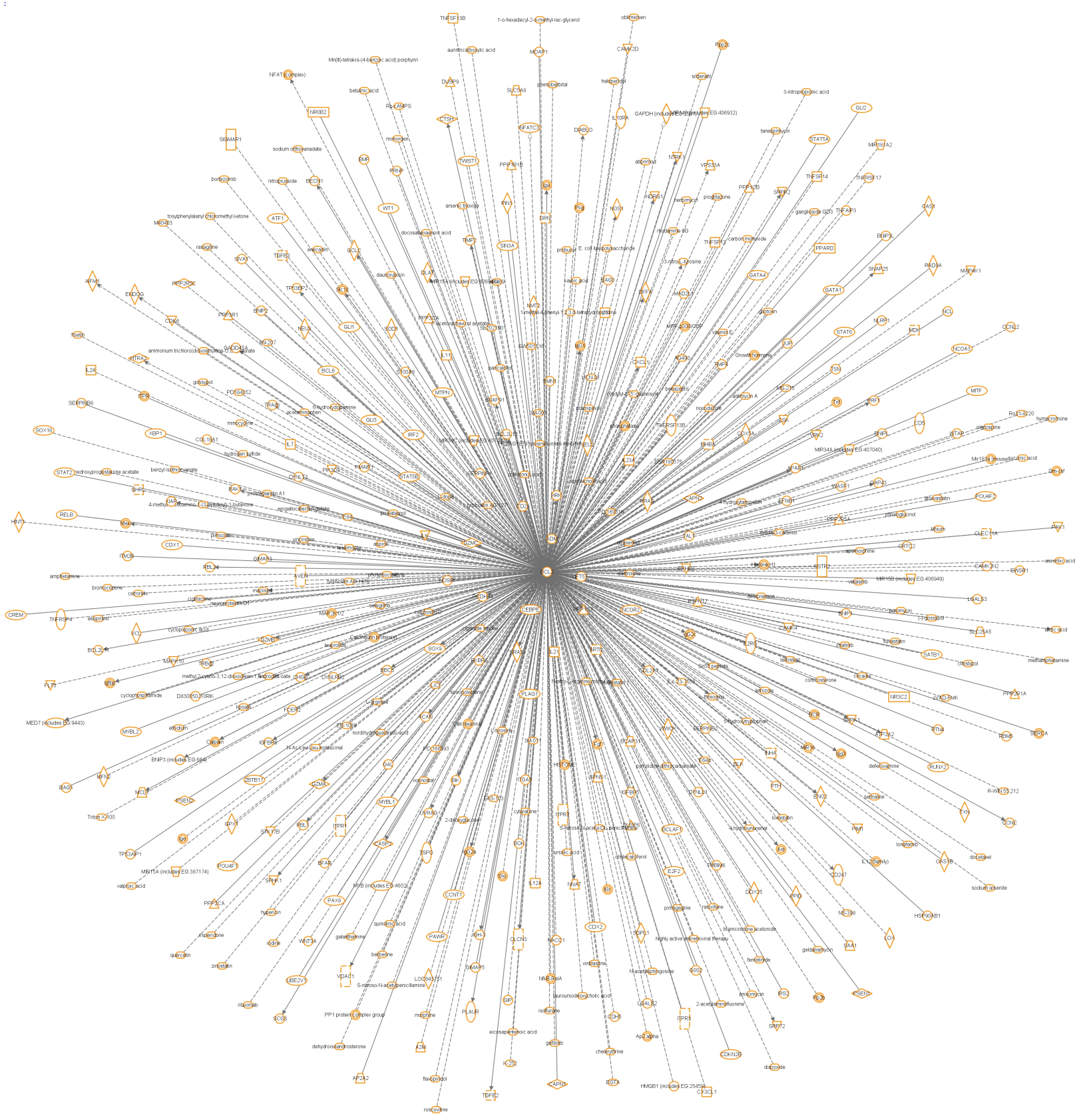


Figure 6B

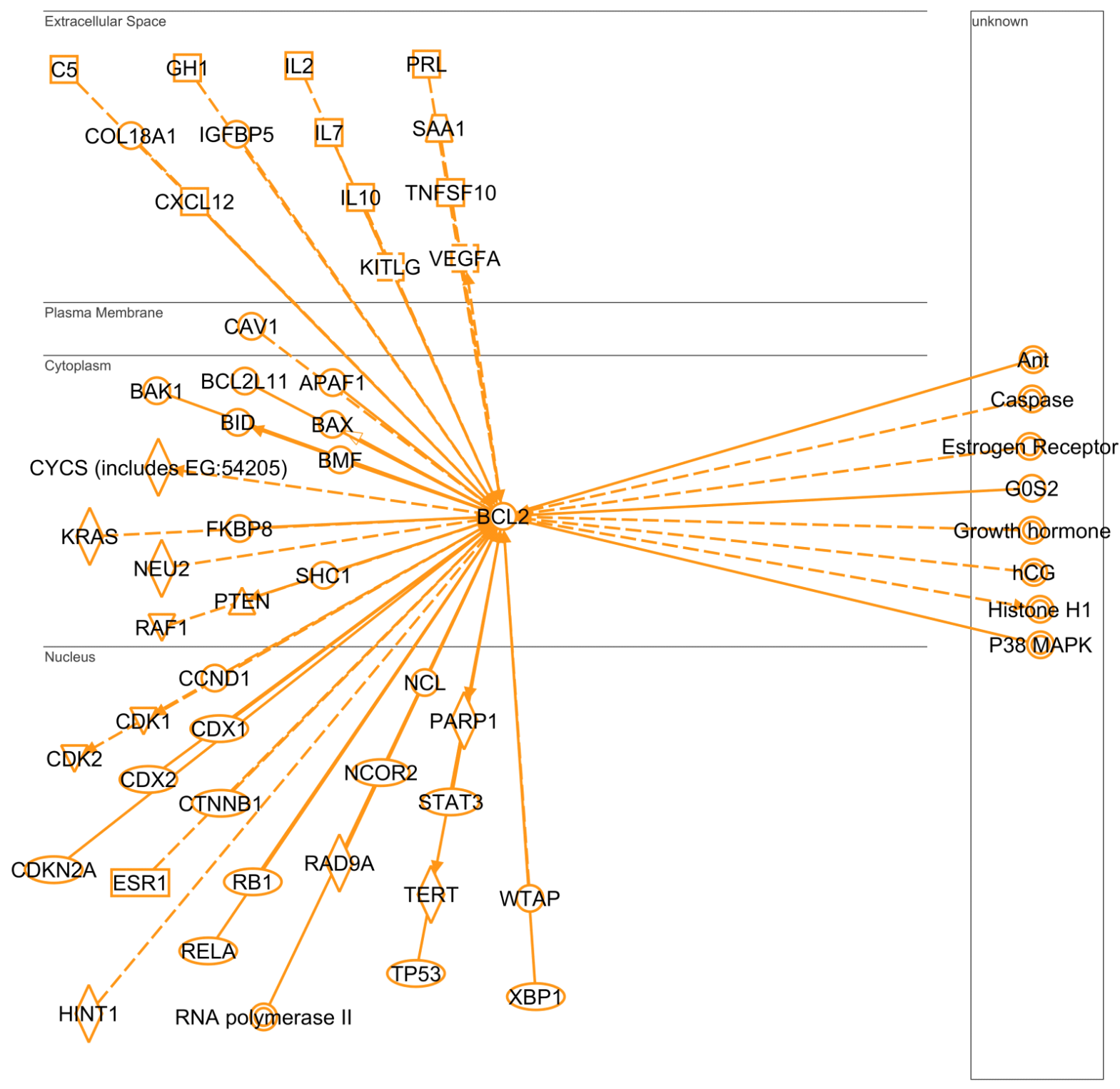


Figure 6C

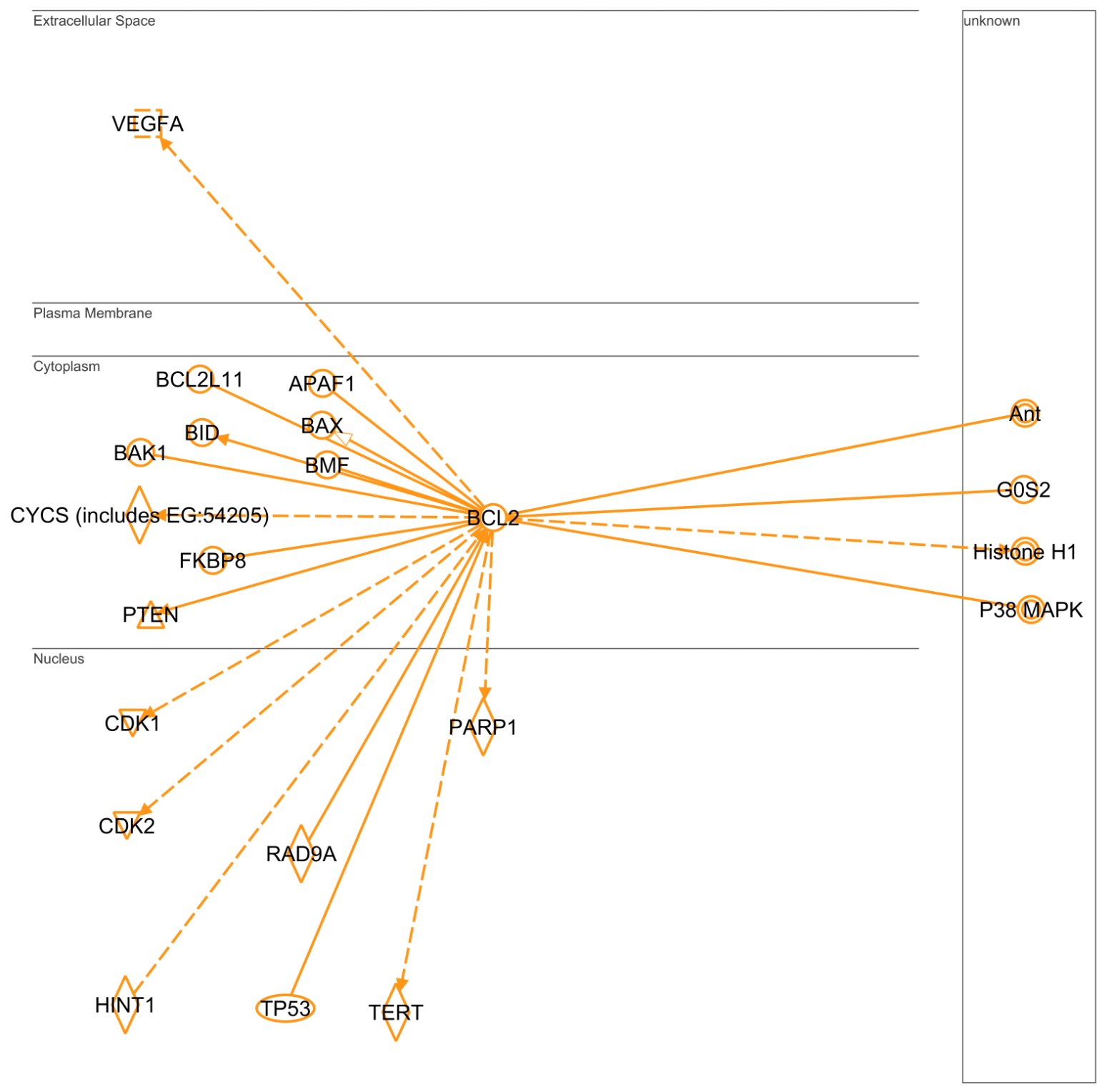

FIGURE 6. Ingenuity Pathways Analysis software output for the $\mathrm{Bcl}-2$ interactome. $A$, Initial IPA query for the Bcl-2-interactome. 741 molecules were reported (as of IPA v8.6, October 5, 2010). B, Bcl-2-interactome filtered for interactions reported in humans only and presented by cellular localization. 56 molecules were reported to interact either directly or indirectly. $C$, Downstream components of human Bcl-2-interactome. 20 molecules were reported to date. 


\subsection{References}

1. Machle, W. and Gregorius, F. (1948) Cancer of the respiratory system in the United States chromate-producing industry. Public Health Rep. 63, 1114-27

2. De Flora, S. (2000) Threshold mechanisms and site specificity in chromium(VI) carcinogenesis. Carcinogenesis 21, 533-41

3. Langard, S. (1990) One hundred years of chromium and cancer: a review of epidemiological evidence and selected case reports. Am. J. Ind. Med. 17, 189-215

4. Langard, S. (1993) Role of chemical species and exposure characteristics in cancer among persons occupationally exposed to chromium compounds. Scand. J. Work Environ. Health 19 Suppl., $181-9$

5. Simonato, L., Fletcher, A.C. and Andersen, A. (1991) A historical prospective study of European stainless steel, mild steel, and shipyard welders. Br. J. Ind. Med. 48, 145-54

6. Woodruff, T.J., Axelrad, D.A., Caldwell, J., Morello-Frosch, R. and Rosenbaum, A. (1998) Public health implications of 1990 air toxics concentrations across the United States. Environ. Health. Perspect. 106, 24551

7. Baetjer, A.M., Lowney, J.F., Steffee, H. and Budacz, V. (1959) Effect of chromium on incidence of lung tumors in mice and rats. AMA Arch. Ind. Health 20, 124-35

8. Hueper, W.C. and Payne, W.W. (1959) Experimental cancers in rats produced by chromium compounds and their significance to industry and public health. Am. Ind. Hyg. Assoc. J. 20, 274-80

9. Mackenzie, R.D., Byerrum, R.U., Decker, C.F., Hoppert, C.A. and Langham, R.F. (1958) Chronic toxicity studies. II. Hexavalent and trivalent chromium administered in drinking water to rats. AMA Arch. Ind. Health 18, 232-4

10. IARC Monograph on the evaluation of carcinogenic risk to humans. (1990) Chromium, Nickel and Welding 49, Lyon, France 
11. Azad, N., Vallyathan, V., Wang, L., Tantishaiyakul, V., Stehlik, C., Leonard, S.S., and Rojanasakul, Y. (2006) S-nitrosylation of Bcl-2 inhibits its ubiquitinproteasomal degradation. A novel antiapoptotic mechanism that suppresses apoptosis. J. Biol. Chem. 281, 34124-34

12. Azad, N., Iyer, A.K., Wang, L., Lu, Y., Medan, D., Castranova, V. and Rojanasakul, Y. (2010) Nitric oxide-mediated bcl-2 stabilization potentiates malignant transformation of human lung epithelial cells. Am. J. Respir. Cell Mol. Biol. 42, 578-85

13. Ben-Ezra, J.M., Kornstein, M.J., Grimes, M.M. and Krystal, G. (1994) Small cell carcinomas of the lung express the Bcl-2 protein. Am. J. Pathol. 145, 1036-40

14. Ikegaki, N., Katsumata, M., Minna, J. and Tsujimoto, Y. (1994) Expression of bcl-2 in small cell lung carcinoma cells. Cancer Res. 54, 6-8

15. Jiang, S.X., Sato, Y., Kuwao, S. and Kameya, T. (1995) Expression of bcl-2 oncogene protein is prevalent in small cell lung carcinomas. J. Pathol. 177 135-8

16. Buolamwini, J.K. (1999) Novel anticancer drug discovery. Curr. Opin. Chem. Biol. 3 500-9

17. Osford, S.M., Dallman, C.L., Johnson, P.W., Ganesan, A. and Packham, G. (2004) Current strategies to target the anti-apoptotic Bcl-2 protein in cancer cells. Curr. Med. Chem. 11, 1031-9

18. Clark, G.J., Cox, A.D., Graham, S.M. and Der, C.J. (1995) Biological assays for Ras transformation. Methods Enzymol. 255, 395-412

19. Gerwin, B.I., Spillare, E., Forrester, K., Lehman, T.A., Kispert, J., Welsh, J.A., Pfeifer, A.M., Lechner, J.F., Baker, S.J. and Vogelstein, B., (1992) Mutant p53 can induce tumorigenic conversion of human bronchial epithelial cells and reduce their responsiveness to a negative growth factor, transforming growth factor beta 1. Proc. Natl. Acad. Sci. U S A 89, 2759-63

20. Khatlani, T.S., Wislez, M., Sun, M., Srinivas, H., Iwanaga, K., Ma, L., Hanna, A.E., Liu, D., Girard, L., Kim, Y.H., Pollack, J.R., Minna, J.D., Wistuba, I.I. and Kurie, J.M. (2007) c-Jun N-terminal kinase is activated in non-small-cell lung 
cancer and promotes neoplastic transformation in human bronchial epithelial cells. Oncogene 26, 2658-66

21. Lehman, T.A., Reddel, R., Peiifer, A.M., Spillare, E., Kaighn, M.E., Weston, A., Gerwin, B.I. and Harris, C.C. (1991) Oncogenes and tumor-suppressor genes. Environ. Health Perspect. 93, 133-4

22. Carlisle, D.L., Pritchard, D.E., Singh, J. and Patierno, S.R. (2004) Chromium (VI) induces p53-dependent apoptosis in diploid human lung and mouse dermal fibroblasts. Mol. Carcinogenesis 28, 111-8

23. Carney, D.N., Gazdar, A.F. and Minna, J.D. (1980) Positive correlation between histological tumor involvement and generation of tumor cell colonies in agarose in specimens taken directly from patients with small-cell carcinoma of the lung. Cancer Res. 40, 1820-3

24. Van Vleet, T.R., Watterson, T.L., Klein, P.J. and Coulombe, R.A. Jr. (2006) Aflatoxin B1 alters the expression of p53 in cytochrome P450-expressing human lung cells. Toxicol. Sci. 89, 399-407

25. Ke, Y., Reddel, R.R., Gerwin, B.I., Miyashita, M., McMenamin, M., Lechner, JF. and Harris, C.C. (1988) Human bronchial epithelial cells with integrated SV40 virus $T$ antigen genes retain the ability to undergo squmous differentiation. Differentiation 38, 60-6

26. Hanahan, D. and Weinberg, R.A. (2000) The hallmarks of cancer. Cell 100, 57-70

27. Fusenig, N.E. and Boukamp, P. (1998) Multiple stages and genetic alterations in immortalization, malignant transformation, and tumor progression of human skin keratinocytes. Mol. Carcinogenesis 23, 144-58

28. Chao, D.T. and Korsmeyer, S.J. (1998) BCL-2 family: regulators of cell death. Annu. Rev. Immunol. 16, 395-419

29. Hickman, J.A. (2002) Apoptosis and tumourigenesis. Curr. Opin. Genet. Dev. $12,67-72$ 


\section{OVERALL CONCLUSIONS}

- $\mathrm{Cr}(\mathrm{VI})$ induces apoptosis in cancerous $\mathrm{H} 460$ cells and non-cancerous BEAS2B cells in a dose dependent manner.

- Cancerous H460 cells exhibit 4-fold native resistance to $\mathrm{Cr}(\mathrm{VI})$-induced apoptosis.

- The native apoptosis resistance of cancerous $\mathrm{H} 460$ cells is abrogated when oxidative phosphorylation-only metabolism is forced.

- ROS play a key role in $\mathrm{Cr}(\mathrm{VI})$-induced apoptosis signaling.

- The primary, apoptosis relevant, source of ROS is mitochondrion.

- mROS intensity is increased in cancerous H460 cells but not in noncancerous BEAS-2B cells when oxidative phosphorylation-only metabolism is forced.

- Inhibition of mROS as well as outer mitochondrial membrane signaling (via $\mathrm{Bcl}-2)$ leads to inhibition of $\mathrm{Cr}(\mathrm{VI})$-induced apoptosis.

- Prolonged exposure of non-cancerous BEAS-2B cells to sub-lethal $\mathrm{Cr}(\mathrm{VI})$ dose leads to transformation and evolution of malignant phenotype.

- Cell growth, colony formation, migration and invasion capacities of transformed BEAS-2B (BEAS-Cr) cells are substantially elevated in vitro.

- Stable and selective knockdown of Bcl-2 leads to significant reduction in tumor-associated properties in vitro in human lung cancer $\mathrm{H} 460$ and laboratory evolved malignant BEAS-Cr cells.

- Stable and selective knockdown of $\mathrm{Bcl}-2$ leads to comparable reduction in tumor-associated properties in vivo in human lung cancer $\mathrm{H} 460$ and laboratory evolved malignant BEAS-Cr cells.

- $\mathrm{Cr}(\mathrm{VI})$-induced malignant transformation of human lung epithelial cells is of clear relevance to human exposure and validates human lung epithelial cells as a direct target for $\mathrm{Cr}(\mathrm{VI})$-induced carcinogenesis. 


\section{Djordje Medan}

208 Dewey St. Morgantown, WV, 26501

Email: dmedan08@gmail.com

Phone: (304) 319-8046

Phone2: (707) 932-5340

\section{OBJECTIVE}

Continue the quest for deeper understanding of mitochondrial molecular biology and physiology.

\section{EDUCATION}

- PhD, Pharmaceutical and Pharmacological Sciences, May 2011, Department of Basic Pharmaceutical Sciences, West Virginia University, WV, USA.

- MS, Pharmaceutical Sciences, May 2003, Department of Basic Pharmaceutical Sciences, West Virginia University, WV, USA.

- BS, Biology with Minor in Chemistry, May 1998, West Virginia Wesleyan College, Buckhannon, WV, USA

\section{MERITS \& HONORS}

\section{Research Awards:}

- Research Award in Pharmaceutical Biotechnology -

American Association of Pharmaceutical Scientists

(sponsored by Pfizer Global Biologics) (2004).

\section{SKILL SET}

- Development and validation of small-molecule bioanalytical methods (U/HPLC-MS/MS, Fluorescence, UV) in high-throughput, robotics supported environment meeting FDA GLP guidelines for human clinical studies.

- Design, evaluation and integration of new technological platforms for advancement of analytical capabilities 
- Design of FDA compliant bioanalytical laboratory standard operating procedures

- Cell culture of various human cell lines.

- Assays for cell proliferation, migration, invasion, viability and death.

- Western blotting, immunoprecipitation, fluorescence microscopy.

- DNA and siRNA transfection, preparation of stable cell-lines.

- DNA cloning using PCR and Site-directed mutagenesis.

- Flow cytometry, spectrophotometry, spectrofluorometry.

- ELISA, soft agar assay

- DNA fragmentation assays

\section{PUBLICATIONS.}

\section{SCIENTIFIC PAPERS:}

- Medan D, Wang L, Lu Y, Davis ME, Jiang BH, Barnett JB, Guo L, Rojanasakul Y. Malignant transformation and tumorigenesis of chromium (VI)-transformed lung cells and their inhibition by Bcl-2 knockdown. Submitted.

- Medan D, Wang L, LuY, RojanasakulY. Energy substrate modulates $\mathrm{Cr}(\mathrm{VI})$-induced apoptosis in human lung cancer cells via a mitochondrial reactive oxygen species-dependent mechanism. Submission preparation.

- Azad N, lyer AK, Wang L, Lu Y, Medan D, Castranova V, Rojanasakul Y. Nitric oxide-mediated bcl-2 stabilization potentiates malignant transformation of human lung epithelial cells. Am J Respir Cell Mol Biol. 2010 May;42(5):578-85.

- Lu B, Wang L, Stehlik C, Medan D, Huang C, Hu S, Chen F, Shi X, Rojanasakul Y. Phosphatidylinositol 3-kinase/Akt positively regulates Fas (CD95)-mediated apoptosis in epidermal Cl41 cells. J Immunol. 2006 Jun 1;176(11):6785-93.

- Medan D, Wang L, Toledo D, Lu B, Stehlik C, Jiang BH, Shi X, Rojanasakul Y. Regulation of Fas (CD95)-induced apoptotic and necrotic cell death by reactive oxygen species in macrophages. J Cell Physiol. 2005 Apr;203(1):78-84.

- Wang L, Medan D, Mercer R, Overmiller D, Leornard S, Castranova V, Shi $X$, Ding M, Huang C, Rojanasakul Y. Vanadium-induced apoptosis and pulmonary inflammation in mice: Role of reactive oxygen species. J Cell Physiol. 2003 Apr;195(1):99-107.

- Wang L, Medan D, Mercer R, Shi X, Huang C, Castranova V, Ding M, Rojanasakul $Y$. Role of neutrophil apoptosis in vanadium-induced pulmonary inflammation in mice. J Environ Pathol Toxicol Oncol. 2002;21(4):343-50.

- Lu B, Wang L, Medan D, Toledo D, Huang C, Chen F, Shi X, Rojanasakul $\mathrm{Y}$. Regulation of Fas (CD95)-induced apoptosis by nuclear factor- $\kappa \mathrm{B}$ and tumor necrosis factor- $\alpha$ in macrophages. Am J Physiol Cell Physiol. 2002 Sep;283(3):C831-8. 
- Medan D, Wang L, Yang X, Dokka S, Castranova V, Rojanasakul Y. Induction of neutrophil apoptosis and secondary necrosis during endotoxininduced pulmonary inflammation in mice. J Cell Physiol. 2002 Jun;191(3):320-6.

\section{WORK EXPERIENCE}

- June 1998-March 2008 - Bioanalytical Laboratory, R\&D, Mylan Pharmaceuticals Inc.

Titles held:

Chemist 1998-2000

Senior Chemist 2000-2003

Scientist 2003-2006

Senior Scientist 2006-2008

- WVU School of Pharmacy, Concurrent with Mylan 2000-2008, 2008-Present

- Mentor - Dr. Yon Rojanasakul

Identification of key molecular targets involved in lung cancer induced by environmental and occupational carcinogens such as hexavalent chromium [ $\mathrm{Cr}(\mathrm{VI})]$ compounds.

Findings will recognize novel therapeutic targets and important biological mediators such as reactive oxygen species in lung carcinogenesis induced by $\mathrm{Cr}(\mathrm{VI})$ and other mutagenic agents.

Mentored two graduate students and 4 summer interns during the period of my graduate work at WVU. Currently, one graduate student is an assistant professor and the other one is pursuing a graduate career.

- Aug 2008 - June 2010 Teaching Assistant, Department of Basic PharmaceuticalSciences, West Virginia University.

Taught and managed pharmacy, graded homework, proctored exams, conducted and supervised experiments for PCL-1 (Pharmacy) labs.

\section{PROFESSIONAL AFFILIATIONS}

- Student member of the American Association of Pharmaceutical Scientists (AAPS) since 2001.

- Professional member of American Society for Mass 
Spectrometry (ASMS) since 2006.

\section{INTERESTS}

- Information technology

- Global capital markets

- Real Estate

- Golf

- Photography 